Florida International University FIU Digital Commons

2-27-2014

\title{
U.S. Construction Worker Fall Accidents: Their Causes And Influential Factors
}

Sohaib Siddiqui

sohaibsidd@gmail.com

DOI: $10.25148 /$ etd.FI14040808

Follow this and additional works at: https://digitalcommons.fiu.edu/etd

Part of the Construction Engineering and Management Commons

\section{Recommended Citation}

Siddiqui, Sohaib, "U.S. Construction Worker Fall Accidents: Their Causes And Influential Factors" (2014). FIU Electronic Theses and Dissertations. 1157.

https://digitalcommons.fiu.edu/etd/1157

This work is brought to you for free and open access by the University Graduate School at FIU Digital Commons. It has been accepted for inclusion in FIU Electronic Theses and Dissertations by an authorized administrator of FIU Digital Commons. For more information, please contact dcc@fiu.edu. 


\title{
FLORIDA INTERNATIONAL UNIVERSITY \\ Miami, Florida
}

\section{U.S. CONSTRUCTION WORKER FALL ACCIDENTS: THEIR CAUSES AND INFLUENTIAL FACTORS}

\author{
A thesis submitted in partial fulfillment of \\ the requirements for the degree of \\ MASTER OF SCIENCE \\ in \\ CONSTRUCTION MANAGEMENT \\ by
}

Sohaib Siddiqui 
To: Dean Amir Mirmiran

College of Engineering and Computing

This thesis, written by Sohaib Siddiqui, and entitled U.S. Construction Worker Fall Accidents: Their Causes and Influential Factors, having been approved in respect to style and intellectual content, is referred to you for judgment.

We have read this thesis and recommend that it be approved.

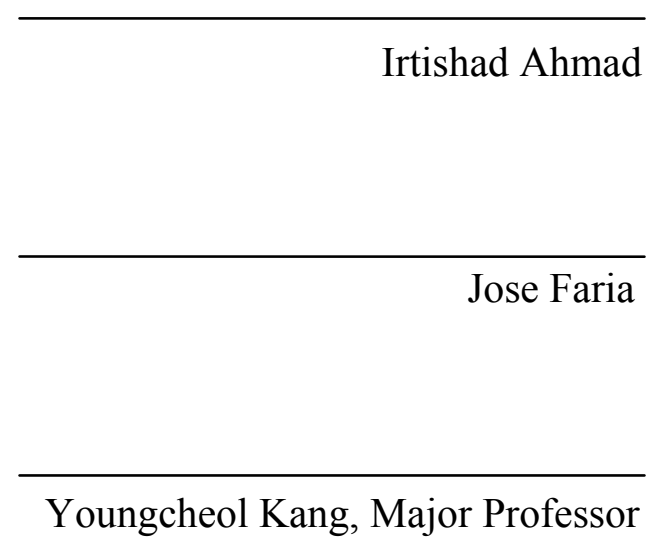

Date of Defense: February 27, 2014

The thesis of Sohaib Siddiqui is approved.

Dean Amir Mirmiran

College of Engineering and Computing

Dean Lakshmi N. Reddi

University Graduate School

Florida International University, 2014 


\section{DEDICATION}

This thesis is dedicated to my family especially my mother, my father, my wife and my daughter; as without their unwavering support and blessings, this academic milestone would not have been possible to achieve. To Dr. Youngcheol Kang, as without his remarkable direction and support this thesis would not have been feasible. In the end, I would like to dedicate this work to one of the most celebrated researchers in the field of

health and safety in construction, Late Dr. Jimmie Hinze, who recently lost the battle of his life to cancer. 


\section{ACKNOWLEDGMENTS}

All the praise and glory to Almighty Allah (SWT), for His unlimited bounties and blessings, without which this thesis would not have been possible.

I would like to present my sincerest gratitude to my major advisor, Dr. Youngcheol Kang for his utmost guidance and extremely important directions which led to successful completion of this thesis; this research would not have been possible without his outstanding supervision. This accomplishment would also not have been possible without the continuous support and leadership of the program chair, Dr. Irtishad Ahmad. I would like to take the opportunity to express my gratitude Dr. Jose Faria for his guidance and helpful insights.

I would also like to thank Ms. Vergie Bain from Occupational Safety and Health Administration, as without her help and guidance procurement of OSHA's IMIS database would not have been possible.

In the end, I would like to thank all the friends and staff at the OHL School of Construction for their continual support and help throughout my research work. 
ABSTRACT OF THE THESIS

\title{
U.S. CONSTRUCTION WORKER FALL ACCIDENTS: THEIR CAUSES AND
}

\section{INFLUENTIAL FACTORS}

\author{
by
}

Sohaib Siddiqui

Florida International University, 2014

Miami, Florida

\section{Professor Youngcheol Kang, Major Professor}

The purpose of this study is to investigate the main causes of fall accidents and, to pinpoint the factors that influence the risk of falls in the U.S. construction industry. This study employed the Integrated Management Information System (IMIS) data from the Occupational Safety and Health Administration (OSHA) to examine 9,141 fall accidents, recorded for the period of last 20 years. The results show that specialty trade contractors working on low-budget, residential housing and commercial building projects are more susceptible to fall accidents. In terms of fall height, $85 \%$ of the fall accidents occurred on heights less than $30 \mathrm{ft}$., and most of them are not equipped with a fall protection tool. The main contribution of this study is that it has specifically analyzed fall heights and the current state of usage of fall protection using actual accident data. Since there has been hardly any research done in the last decade to study falls in the U.S. construction industry, by examining the IMIS database; this study also presents updated analysis on fall accidents. 


\section{TABLE OF CONTENTS}

CHAPTER

PAGE

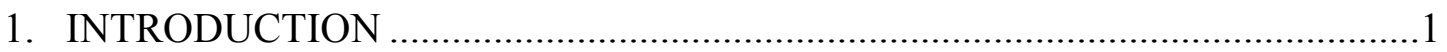

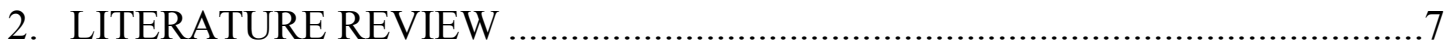

2.1 Falls in the U.S. construction industry ....................................................

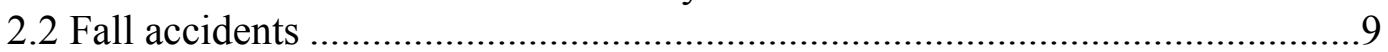

$2.3 \mathrm{OSH}$ Act and OSHA's fall protection regulations ....................................28

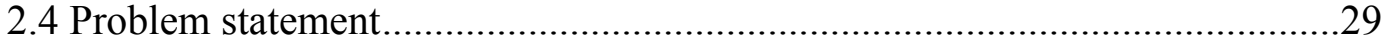

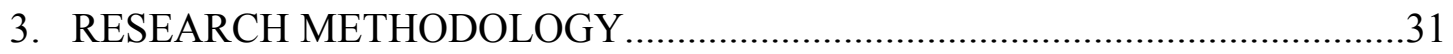

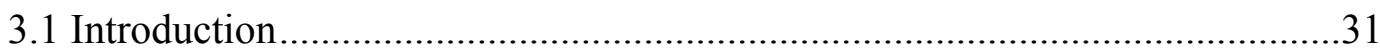

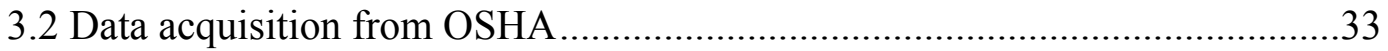

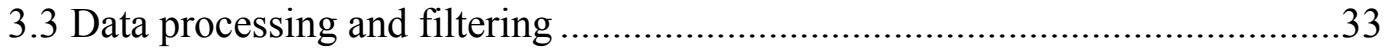

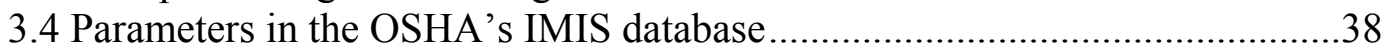

3.5 Review of the database and coding of additional parameters ..........................39

3.6 Coding of new parameters (fall cause, fall height and fall protection)............40

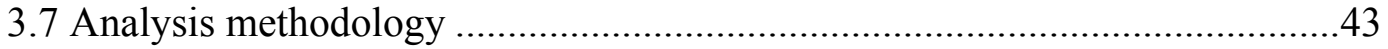

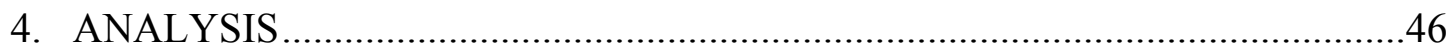

4.1 Comparison of fall accidents with other major types of accidents .................47

4.2 Analysis by industry type (SIC) and project characteristics .........................52

4.3 Analysis by trades, fall cause, fall height, fall protection, \& nature of injuries ...60

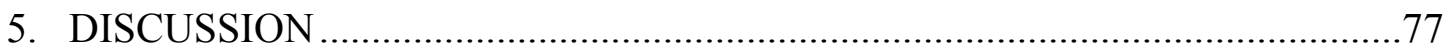

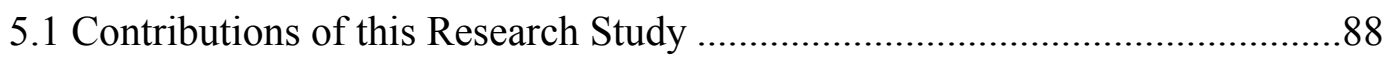

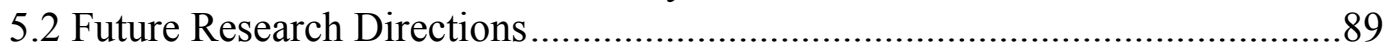

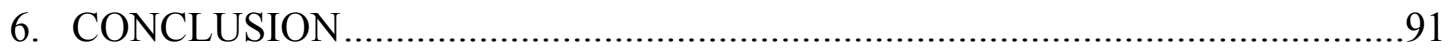

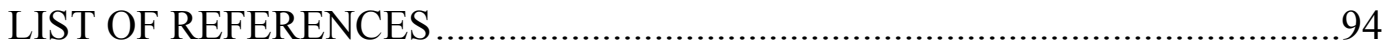




\section{LIST OF TABLES}

TABLE

PAGE

2-1 Percentage of falls in the U.S. construction industry by previous studies. 9

2-2 Falls with respect to industry type (SIC) as noted by previous studies 14

2-3 Falls by construction end use by Huang and Hinze (2003) and Hatipkarasulu (2010).....15

2-4 Falls with respect to nature of construction by Huang and Hinze (2003) ...................16

2-5 Falls with respect to project budget by Huang and Hinze (2003) .............................17

2-6 Falls with respect to different trades as noted by previous studies ...........................20

2-7 Causes of fall accidents by Huang and Hinze (2003) ............................................21

2-8 Fall heights by Huang and Hinze (2003) and Saruda et al. (1995) ............................23

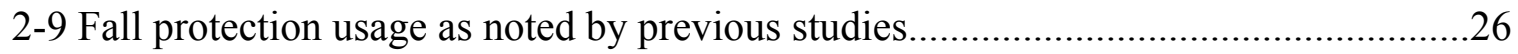

3-1 List of available parameters in the OSHA's IMIS database.....................................39

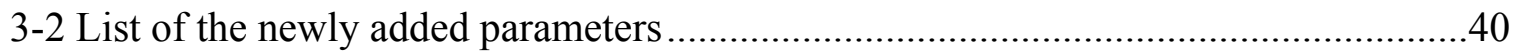

3-3 List of the coded fall causal parameters ................................................................ 41

3-4 Details of parameters coded for fall protection ................................................43

3-5 List of major parameters analyzed in the descriptive analysis phase ........................44

4-1 Comparison of percentage of occurrence of fatal four accidents ............................48

4-2 Percentage of fall accidents (Nov-2001 to May-2013) ........................................49

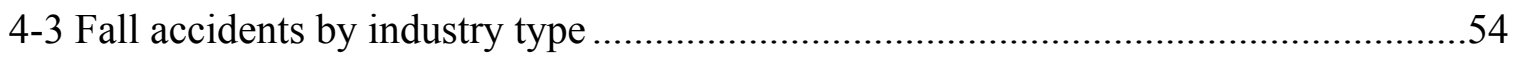

4-4 Comparison of fall accidents by different construction end uses .............................56

4-5 Comparison of falls with respect to nature of construction ....................................57

4-6 Comparison of fall accidents with respect to cost of project.................................59

4-7 Percentage of fall accidents in major fall prone trade categories ............................62 
4-8 Comparison of percentage of major causes of fall accidents .................................64

4-9 Comparison of fall accidents with respect to different height (ft.) intervals ..............67

4-10 Comparison of usage of fall protection from previous studies............................... 70

4-11 Trend of usage of fall protection at different height intervals .............................. 71

5-1 Comparison of Education requirements and Compensation of different Trades ........85 


\section{LIST OF FIGURES}

FIGURE

PAGE

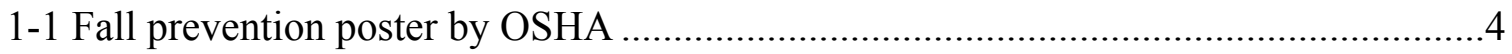

1-2 Screenshot of website stopconstructionfalls.com ................................................

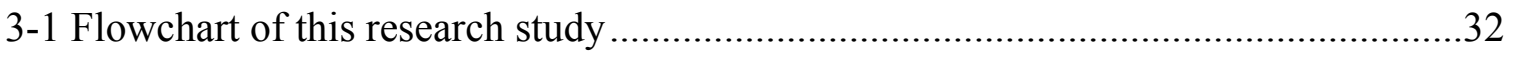

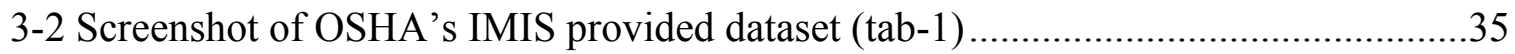

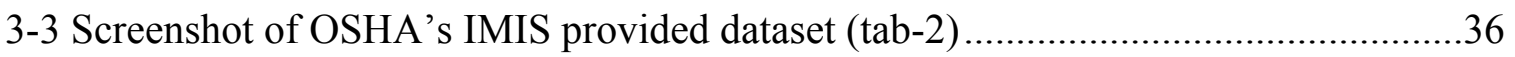

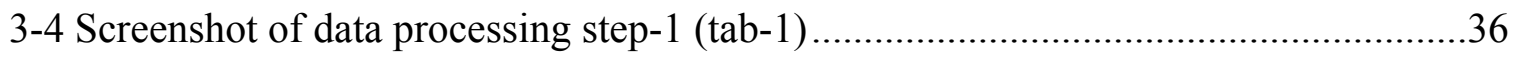

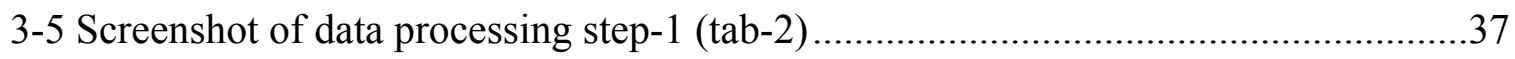

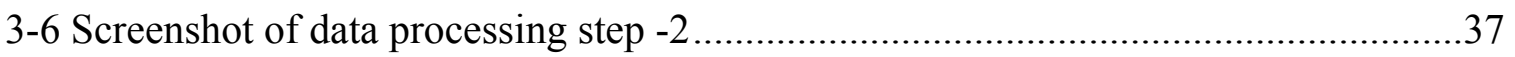

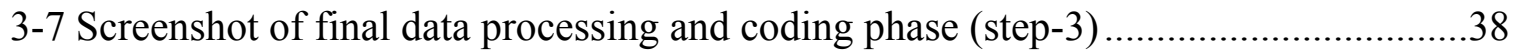

4-1 Percentage of occurrence of major types of accidents ..........................................47

4-2 Trend of falls in the U.S. construction industry (1996-2013) .................................50

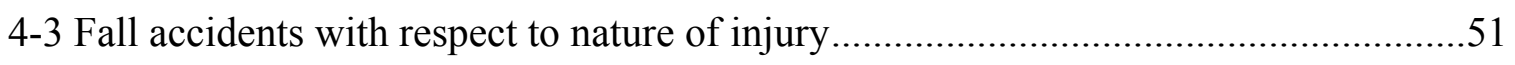

4-4 Comparison of severity of accident in OSHA's fatal four .....................................52

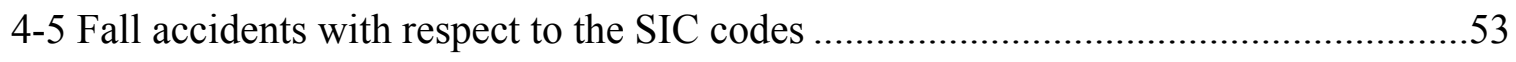

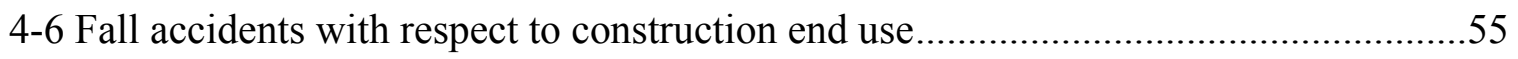

4-7 Fall accidents with respect to type of construction..............................................57

4-8 Fall accidents with respect to cost of the project...................................................58

4-9 Fall accidents with respect to different trades/ professions (SIC Codes) ..................61

4-10 Percentage of occurrence of various fall causal codes/ factors ............................63

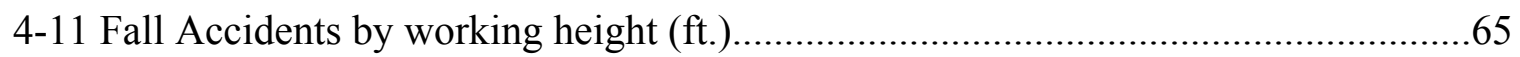

4-12 Average height of fall (ft.) for various types of construction end uses ...................66 
4-13 Fall protection usage in the U.S. construction industry.

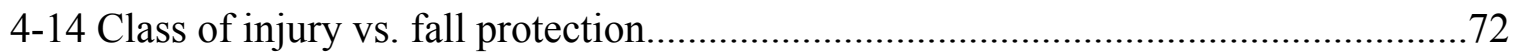

4-15 Nature of injury and fall Protection usage in roofing works .................................73

4-16 Average height of fall in roofing vs. fall protection ............................................. 74

4-17 Nature of injury and fall protection usage in steel erection works ..........................75

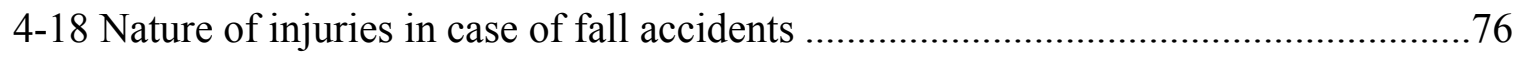

5-1 Value of residential vs. non-residential construction, 1993-2010 ...........................78

5-2 Work done in residential construction sector by selected specialty trades.................80

5-3 OSHA's federal citations by major violation category and construction Sector.........83 


\section{LIST OF ACRONYMS}

CFOI Census of Fatal Occupational Injuries

CPS Current Population Survey

HIOSH Hawaii Occupational Safety and Health Division

IMIS Integrated Management Information System

NAICS North American Industrial Classification System

NIOSH National Institute of Occupational Safety and Health

NTOF National Traumatic Occupational Fatality

OSHA Occupational Safety and Health Administration

PPE Personal Protective Equipment

SIC Standard Industrial Classification Code

U.S. United States of America 


\section{CHAPTER 1: INTRODUCTION}

The construction business is one of the major sources of employment in the United States', employing over 9 million workers who account for around $7 \%$ of the total United States workforce. In 2010 , the construction industry made up about $3.5 \%$ of the total gross domestic product of the United States (The Construction Chart Book, 2013). Construction is considered to be one of the most dangerous occupations, due to its dynamic nature and outside work operations. Construction work usually involves working at heights, and working in complex work environments that make it riskier with regards to worker safety and health (National Institute of Safety and Health [NIOSH], 2002, 2004; National Safety Council [NSC], 2008; U.S. Bureau of Labor Statistics [BLS], 2002, 2007).

Occupational injuries and fatalities in the construction industry mean not only the loss of precious lives and reduction in quality of lives but also delays in construction and a financial burden on employers and workers. The direct cost effect of injuries and fatalities in the construction industry may be as much as billions of dollars annually (Hallowell, 2010), whereas the indirect cost impact is estimated to be six times the direct costs (Chen, Fisher, \& Krishnamurthy, 1994; Gavious, Mizrahi, Shani, \& Minchuk, 2009). Accident prevention and control in the construction industry is a matter of huge concern, as the business exhibits one of the worst safety records among various high-risk sectors including the chemical industry, mining, and transportation (Hallowell, 2010; Sa, Seo \& Choi, 2009). With a current projection of additional 1.8 million jobs and 33\% increase in size of the construction industry of the United States by 2020 (Henderson, 
2012); the persistent problem of health and safety needs to be addressed with greater precision to control work-place accidents and to move towards the target of "Zero Accidents". Better safety and hazard management will reduce numerous social problems of the construction workers and their families; moreover, it will save the employers as well as the employees from the economic burden associated with such incidents.

More than 21,000 construction workers have lost their lives from occupational injuries in the construction industry of the United States from the year 1992 to 2010, averaging 1,050 deaths per year as per the statistics published by U.S. Bureau of Labor and Statistics. Occupational Safety and Health Administration (OSHA) is a regulatory authority, which works under the U.S. Department of Labor and is responsible for the development and enforcement of job safety and health standards. OSHA came into being in 1970, until then there was no authority in the United States for overseeing and regulating work related safety and health issues. When OSHA was established, they encountered worst situation in regards to workers' safety and health; on an average 38 people lost their lives every day at work (OSHA, 2013a). OSHA is playing a very prominent role in controlling the workplace injuries and fatalities in the United States; workplace fatalities are reduced by $65 \%$ and occupational injury and illness rates have dropped by 67\% (OSHA, 2013a). OSHA sets forth its standards for the following industrial categories: general industry, construction, maritime and agriculture industry.

Fall accidents are the main cause of injuries and fatalities in the U.S. construction industry (Bobick, 2004; Hu, Rahmandad, Smith-Jackson, \& Winchester, 2011; Huang \& Hinze, 2003). Although the number of fatal work, related deaths in construction declined 
from 1297 in 2006 to 802 in 2010 , falls continue to be a major problem contributing to nearly one-third of the fatal accidents in the U.S. construction industry (The Construction Chart Book, 2013). The severity of the problem of falls in the U.S. construction industry can be ascertained from the fact that it is leading the list of OSHA's fatal four, followed by struck by, electrocution, and caught in/ between. OSHA's fatal four are the four most recurring workplace incidents and they were responsible for $56 \%$ of construction workers' deaths in 2012 (OSHA, 2013a; BLS, 2012). Despite all these alarming statistics, fall accidents still remain a persistent problem, without any considerable decline whatsoever. In fact, "duty to have fall protection" is the most frequently cited violation for the second consecutive year in 2013, as reported by OSHA (OSHA, 2013c).

OSHA is making an effort to increase the awareness about fall hazards among the stakeholders by imposing training requirements and providing online manuals and occasionally conducting on-site trainings upon the request of the employer (OSHA, 2012). OSHA in collaboration with National Institute of Occupational Safety and Health and National (NIOSH), started a countrywide outreach program to raise awareness among workers and employers about common fall hazards in the construction industry (OSHA, 2013b). The fundamental message of their campaign is to, "Plan ahead to get the job done safely," "provide the right equipment" and "train everyone to use the equipment" (OSHA, 2013b). Moreover, OSHA has provided online manuals and video tutorials which are available in English, Spanish, and other languages, so that employers may download and provide in class training to their workers about hazards. OSHA's website also includes posters showing pictorials of fall hazards that may also be used by 
employers to display at conspicuous locations of their sites so that workers may get warned about the hazards (Fig 1-1).

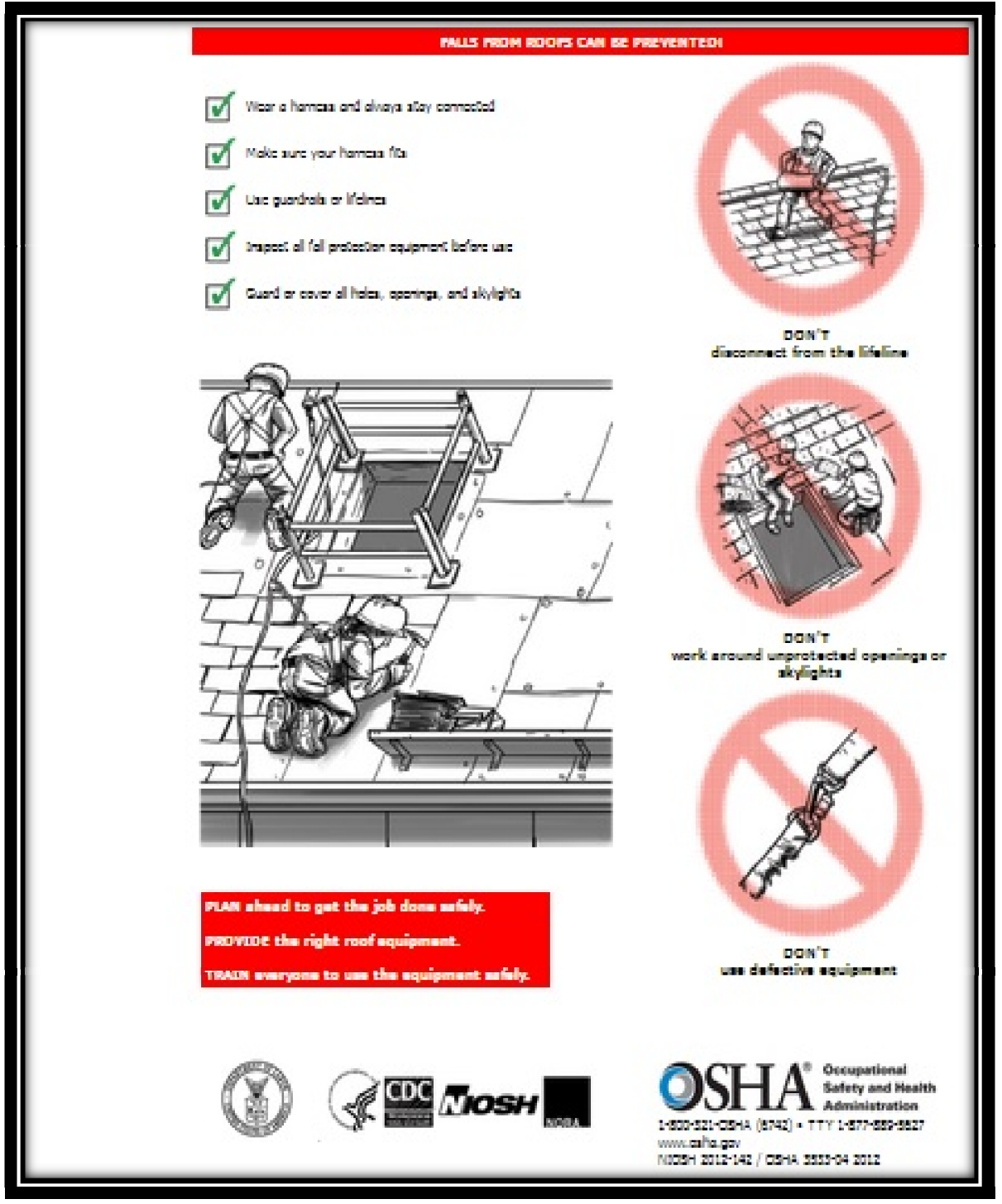

Figure 1-1: Fall Prevention Poster by OSHA

Other than the regulators, stakeholders in the construction industry are also playing their part in increasing awareness about fall hazards and promoting safe work practices in the U.S. construction industry. Safe305 in South Florida is an example of such regional 
alliance between contractors, safety consultants and OSHA. Safe305 conduct meetings every month and provide opportunities for different market players to network and address their problems jointly. Stop Construction Falls is another example of a joint collaboration between government and labor management to address the number one cause of construction fatalities, i.e. falls (Fig 1-2). Their website stopconstructionfalls.com provides online training resources for contractors and workers. Their website also includes links to various campaigns and reports about fall accidents in the U.S. construction industry.

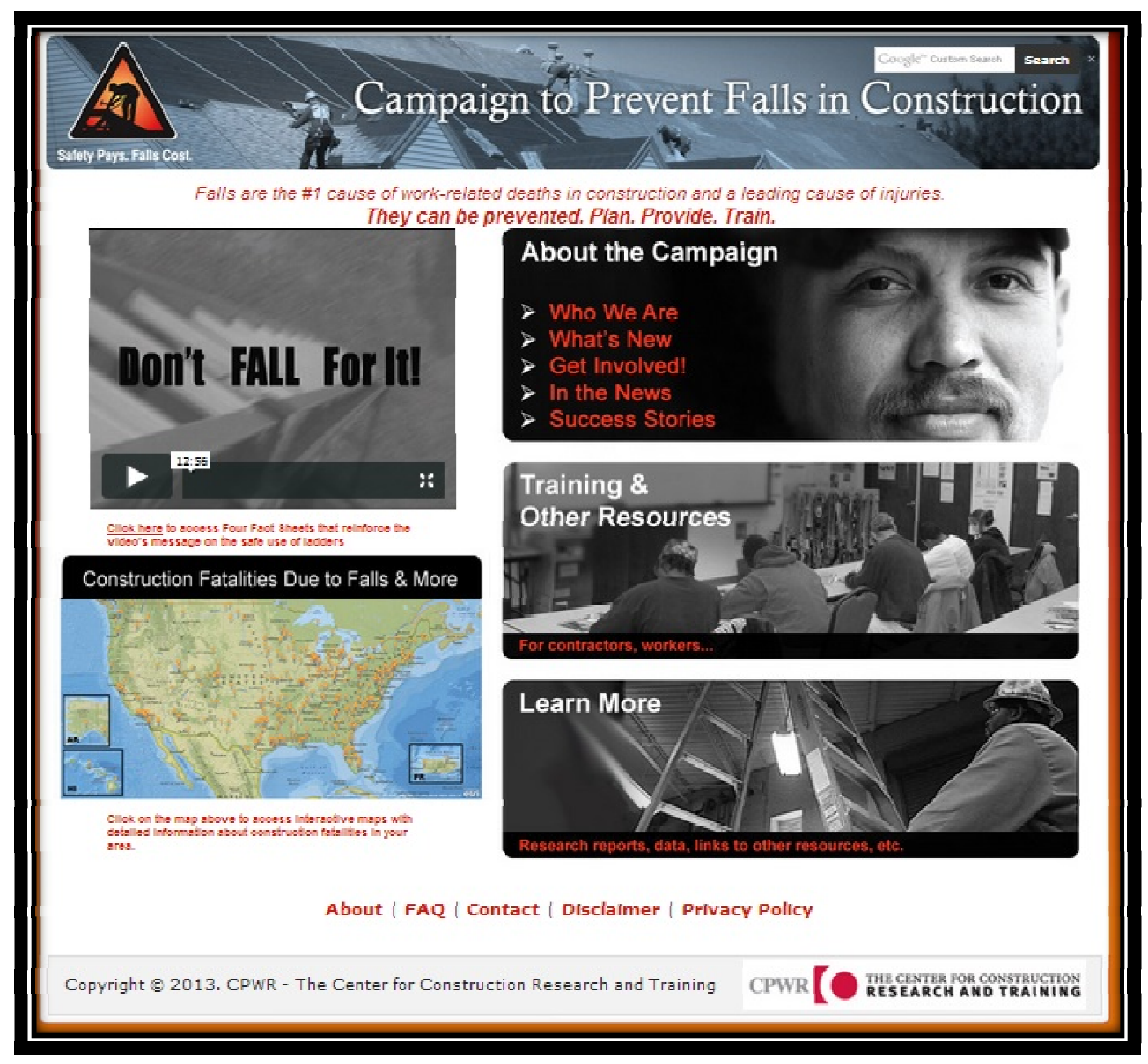

Figure 1-2: Screen shot of website stopconstructionfalls.com 
On the other hand increase in the violation penalties was also made by OSHA to enforce fall protection measures, as Huang and Hinze (2003) noted that fall related citations resulted in higher penalties as compared to other violations.

The purpose of this research study is to identify major causes, dimensions, and trends, influencing the risk of fall accidents in the U.S. construction industry. This study employed the Integrated Management Information System (IMIS) data from the OSHA. Using 9,141 fall accidents collected for the period of the past 20 years (1994-2013), this study examines various characteristics of fall accidents, which are classified into three parts: industry type, project type and size, and dimensions of fall accidents in terms of fall cause, fall height, and the current situation of usage of fall protection. The exclusivity of this study is that it draws its conclusions based on the actual accident data for all the classes of accidents (fatalities, hospitalized injuries and non-hospitalized injuries), unlike previous studies whose findings and conclusions were mostly based on analysis of limited datasets, structured surveys or interviews covering a particular group of persons only. Moreover, the other contribution of this study is that it has specifically analyzed the current state of usage fall protection.

Analysis of the above discussed parameters will lead to the identification of the major causes of fall accidents. The findings of this study will also highlight the current state of compliance to the regulatory laws on a nationwide basis by analyzing the element of fall protection. The results of this study could be used by regulators such as OSHA, NIOSH, etc., in order to effectively address the problem of falls in the U.S. construction industry. 


\section{CHAPTER 2: LITERATURE REVIEW}

Construction industry's workforce is more exposed to safety hazards as compared to the workers in other business sectors, due to its dynamic nature and ever changing work conditions (Hinze \& Applegate, 1991; Lipscomb, Glazner, Bondy, Lezotte, \& Guarini, 2006) . Occupational injuries and fatalities in the construction industry incurs social and financial loses to workers as well as the employers. Since fall accidents usually result in serious injuries, the average days away from work due to a fall to a lower level was found to be 10 days (Bobick, 2004). Bunn, Slavova, and Bathke (2007) has noted, that that falls in construction had the highest workers' compensation and hospitalization costs making it one of the costliest accidents The indirect overhead cost which occurs due to construction injuries and fatalities ultimately results in bad productivity and delays, and is more than the direct cost of the project. The cost factor generated due to liabilities is considered to be a major part of these indirect costs (Hinze, 1991). Accident prevention and control in construction is a matter of huge concern, as this industry exhibits one of the worst safety records among various high risk sectors, which include chemical, mining, and transportation (Sa et al., 2009; Hallowell, 2010). In principle, most of the construction accidents can be either prevented or controlled, but regrettably, there is a very slow progress towards this goal (Gambatese, Behm, \& Rajendran, 2008).

\subsection{Falls in the U.S. Construction Industry}

Fall accidents are the highest cause of work-related injuries and fatalities in the U.S. construction industry, responsible for nearly $35 \%$ of fatalities of all construction worker fatal accidents as analyzed from the U.S. Bureau of Labor and Statistics published 
statistics for the inclusive years of 2003 to 2010. Despite gradual decline in the occupational fatalities, in the U.S. construction industry, falls remain the source of highest fatal occupational injuries and accidents. Falls are considered to be the most costly work-related hazard in many countries (Gavious et al., 2009; Hu et al., 2011). Therefore, prevention and control of fall accidents holds a significant importance in the construction industry globally (Hu et al., 2011). Falls from roofs, ladders and scaffolds constitute a major portion of fall accidents in the U.S. construction industry (Huang \& Hinze, 2003; Janicak, 1998).

Huang and Hinze (2003) analyzed OSHA's IMIS database for 7,543 accidents that occurred in the U.S. construction industry from 1990 to 2001. Falls were found to be the leading cause of the accidents, having a total of 2,741 accidents (36.3\%). In a study about specialty trade contractors by Hatipkarasulu (2010), falls were found to be the highest causal factor leading to fatal accidents, followed by struck by, caught in/ between, heart attack/cardiac arrests, and so on. Beavers, Moore, and Schriver (2009) studied fatalities caused by steel erection works and found that falls were the primary cause of fatalities in the steel erection works, contributing to $75 \%$ of the fatal accidents. Table $2-1$ presents a comparison of fall accidents against other types of accidents as noted by previous studies. 
Table 2-1: Percentage falls in the U.S. construction industry by previous studies

\begin{tabular}{|c|c|c|c|}
\hline $\begin{array}{c}\text { Cause of } \\
\text { Accident }\end{array}$ & $\begin{array}{c}\text { Huang and Hinze } \\
\text { (2003) }\end{array}$ & $\begin{array}{c}\text { Beavers et } \\
\text { al.(2009) (only } \\
\text { structural steel } \\
\text { erection } \\
\text { fatalities) }\end{array}$ & $\begin{array}{c}\text { Hatipkarasulu } \\
\text { (2010) } \\
\text { (only Specialty } \\
\text { Trade Contractors) }\end{array}$ \\
\hline Falls & $36.30 \%$ & $75.30 \%$ & $51.71 \%$ \\
\hline Struck By & $24.30 \%$ & $24.10 \%$ & $22 \%$ \\
\hline $\begin{array}{c}\text { Caught in/ } \\
\text { Between }\end{array}$ & $11.60 \%$ & -- & $6.29 \%$ \\
\hline Shock & $13.40 \%$ & $0.60 \%$ & -- \\
\hline Others & $14.50 \%$ & -- & $20 \%$ \\
\hline
\end{tabular}

\subsection{Fall Accidents}

There have been numerous studies investigating various aspects of fall accidents in the U.S. construction industry. Huang and Hinze (2003) analyzed 1,215 fall related cases (1997-2001) from OSHA's IMIS (Integrated Management Information System) database in order to find main causes of fall accidents. They concluded that specialty trade contractors are more involved in fall accidents, and majority of the falls occured at heights less than $30 \mathrm{ft}$. Low-budget residential housing and commercial building projects are found to be more vulnerable to falls as compared to other types of projects. Moreover, they noted that the workers often underestimate the hazards.

Bobick (2004) investigated "falls through roof and floor openings and surfaces" from 1992-2000 by examining data from the following sources: Census of Fatal Occupational Injuries (CFOI) and Survey of Occupational injuries and illnesses. According to a 
conservative approach, the cost incurred as a result of a fall through injury was found to be ranging in between $\$ 55,000-\$ 76,000$. The researcher also emphasized the usage of commercial fall prevention products in order to reduce the number of accidents and resulting costs.

Janicak (1998) studied work-related fatal accidents in the U.S. construction industry due to falls by analyzing OSHA's fatality inspection data from 1992 to 1995 . There were a total of 1,689 fatality inspections in the construction industry, out of which 965 were falls. Lack of fall protection was found to be the major cause of falls and specialty trade contractors had the greatest share in fall accidents. The average height of fatal falls was found to be $41 \mathrm{ft}$.

Suruda, Fosbroke, and Braddee (1995) studied roof fall fatalities from 1984-1986 by examining death certificates of the victims, that were obtained from NIOSH and National Traumatic Occupational Fatalities (NTOF). Construction industry had 232 fatal falls out of a total of 288 fall accidents. Falls from the roofs and structural steel erection works were found to be the leading cause of fatal falls. The writers also expressed their views regarding the inconsistencies in recording fatalities, as several important factors related to falls could not be found in the investigation summaries.

Hatipkarasulu (2010) did a "project level analysis of specialty trade contractors' fatal accidents" that occurred in the year of 2003. This study examined 350 fatal accidents from OSHA's investigation summaries. Falls were found to be the main cause of work related deaths in residential and commercial building projects. Falls from the roofs was found to be the leading cause of fatalities. 
Sa et al. (2009) studied the "risk factors for falls from height between commercial and residential roofers" by conducting a survey of 301 roofers from the Midwest. Residential roofers were found to be involved in a greater number of fall accidents. Moreover, it has been found that smaller companies have a bad safety record as compared to the big companies. It was concluded that enforcement of safe work practices and usage of fall protection lowers the chances of fall accidents.

Dong, Fujimoto, Ringen, and Men, (2009) studied "fatal work related falls among Hispanic construction workforce" by examining data from Center of Fatal Occupational Injuries (CFOI) and Current Population Survey (CPS). The data set used for this study is from 2003-2006, and it was found that small construction companies are creating a problem in terms of safety in the U.S. construction industry. Small companies generally have less manpower and resources, and their manpower is not usually trained, which ultimately leads to accidents.

A study funded by Hawaii Occupational Safety and Health Division (HIOSH) conducted by Johnson, Singh, and Young (1998) investigated the trend of usage of fall protection systems, behaviors and attitudes of workers in the residential roofing industry of Hawaii. The study was conducted by studying the case histories provided by HIOSH along with the job site inspections, and interviews. It was concluded that the state of compliance to regulations and standards was extremely poor, making residential roofing industry of Hawaii more exposed to fall accidents as compared to other trades. Lack of fall protection was found to be the leading cause of falls. 
Olbina, Hinze, and Ruben (2011) examined the safety practices of Florida roofing contractors that employ Hispanic workers by conducting a survey that was facilitated by Florida roofing, sheet metal and air conditioning contractors. This study found that big companies have better performance in terms of safety as compared to small companies. It was also noted that when Hispanic workers receive training in their native language, they tend to perform better in terms of safety.

Beavers et al. (2009) used OSHA's IMIS database to investigate the causes of workrelated fatalities due to steel erection works. There were 166 cases (2000-2005) that were selected for the analysis. Falls were found to be the leading cause of fatalities for the labor force of the steel erection trade.

Hinze and Gambatese, (2003) explored the aspects that influence the safety performance of specialty trade contractors by conducting structured surveys. Since the study was based on surveys from different specialty contractors, any relationship of injuries and accidents with respect to the size of the company was not established, as in one state the injuries decreased with the increase of the size of the company but for the other two it was vice versa. This study found that accidents and injuries among specialty trade contractors increased with a high turnover rate.

Hung et al. (2012) studied the training needs for the residential roofing contractors by conducting interviews of some selected roofing companies working in the residential roofing sector. This study noted that approaches such as "falls won't happen to me" and the "risk of falls is manageable and controllable" might have contributed to poor show of safety among the participants. This study also identified the shortcomings of safety 
training programs and also recognized a gap between in-class training and actual work practices.

Hu et al. (2011) wrote a review paper in which they discussed about the factors that influence the risk of falls in the construction industry. An extensive literature review has been done for this study, as the researcher's shortlisted 536 papers and finally selected 121 for the study. More than half of the papers were based on the data collected from the U.S. construction industry. Therefore, the results obtained can be considered as a good representative set for the trend of falls in the U.S. construction industry. Parameters influencing the risk of falls included "working surfaces and platforms", "workers' safety behavior and attitudes," and "construction of structure and facilities."

\subsubsection{Fall Accidents with respect to Industry Type}

The Construction industry in the United States has been divided into three different Standard Industrial Classification (SIC) codes namely: SIC-15 (Building Construction), SIC-16 (Heavy Construction) and SIC-17 (Specialty Trade Contractors). SIC codes were developed by the U.S. Federal Government in collaboration with the business community in the early 1930 's to classify diverse economic sectors.

Specialty trade contractors (SIC-17) had the highest incidence rate of work-related fatalities constituting to approximately $58 \%$ of all fatal work related falls in the construction industry in 1994 (Janicak, 1998; BLS). Huang and Hinze (2003) reported that the standards cited for specialty trade contractors (SIC 17), consist half of the fall related citations. Suruda et al. (1995) noted that fatality rates among the roofing workers 
were the highest and SIC-17 (specialty trade contractors) contributed to $74.10 \%$ of the fatal roof falls. Table 2-2 presents the distribution of fall accidents with respect to the SIC codes. It was found that specialty trade contractors are most vulnerable to fall accidents.

Table 2-2: Falls with respect to industry type (SIC) as noted by previous studies

\begin{tabular}{|c|c|c|c|}
\hline Industry Type & $\begin{array}{c}\text { Saruda et al. } \\
\text { (1995) - (only } \\
\text { roof fall } \\
\text { fatalities } \\
\text { considered) }\end{array}$ & $\begin{array}{c}\text { Huang and } \\
\text { Hinze (2003) }\end{array}$ & $\begin{array}{c}\text { Bobick } \\
\text { (2004) (only } \\
\text { fatalities } \\
\text { considered) }\end{array}$ \\
\hline $\begin{array}{c}\text { SIC-15 'General } \\
\text { Building } \\
\text { Construction' }\end{array}$ & $24.50 \%$ & -- & $22.26 \%$ \\
\hline $\begin{array}{c}\text { SIC-16 'Heavy } \\
\text { Construction' }\end{array}$ & $1.40 \%$ & -- & $7.5 \%$ \\
\hline $\begin{array}{c}\text { SIC-17 } \\
\text { Specialty Trade } \\
\text { Contractors' }\end{array}$ & $74.10 \%$ & $80 \%$ & $70.2 \%$ \\
\hline
\end{tabular}

Hinze and Gambatese (2003) reported that accidents and injuries in specialty trade contractors increased with the turnover rate. High turnover means an influx of a greater number of new workers into the job market, and these are the workers who are more prone to accidents and injuries due to lack of experience, training and education. Specialty contractors in general tend to be small sized companies with limited annual revenues (Hinze \& Gambatese, 2003) and higher influx of new workers with such contractors increase the chances of accidents, as these contractors usually do not provide formal safety training and education to their workers. 


\subsubsection{Fall Accidents by Construction End Use and Type of Construction}

There can be various important perspectives about fall accidents to address, and one of the most important is the project at which fall accidents takes place frequently. Table 2-3 shows the percentage of occurrence of fall accidents with respect to the construction end use, as noted by previous researchers. Fall accidents are found to be heavily concentrated in residential housing and commercial building projects.

Table 2-3: Falls by construction end use by Huang and Hinze (2003) and Hatipkarasulu $(2010)$

\begin{tabular}{|c|c|c|}
\hline Construction End Use & $\begin{array}{c}\text { Huang and } \\
\text { Hinze } \\
\text { (2003) }\end{array}$ & $\begin{array}{c}\text { Hatipkarasulu } \\
\text { (2010) }\end{array}$ \\
\hline Commercial Building & $33.30 \%$ & $31.49 \%$ \\
\hline Single Family or Duplex Dwelling & $17.40 \%$ & $40.33 \%$ \\
\hline Other Building & $17.40 \%$ & -- \\
\hline Multi family Dwelling & $9.30 \%$ & -- \\
\hline Manufacturing Plant & $6.50 \%$ & $6.60 \%$ \\
\hline Tower, tank, storage elevator & $5.80 \%$ & $21.45 \%$ \\
\hline Others & $9.8 \%$ & -- \\
\hline
\end{tabular}

Table 2-4 presents the distribution of falls with respect to the nature of construction as noted by Huang and Hinze (2003). New projects or new additions were found to be more susceptible to falls as compared to alteration, maintenance, and demolition works. 
Table 2-4: Falls with respect to nature of construction by Huang and Hinze (2003)

\begin{tabular}{|c|c|}
\hline Type of Construction & $\begin{array}{c}\text { Huang \& } \\
\text { Hinze, (2003) }\end{array}$ \\
\hline $\begin{array}{c}\text { New Project or new } \\
\text { addition }\end{array}$ & $59.30 \%$ \\
\hline $\begin{array}{c}\text { Alteration or } \\
\text { rehabilitation }\end{array}$ & $18.00 \%$ \\
\hline Maintenance or repair & $15.60 \%$ \\
\hline Other & $3.40 \%$ \\
\hline Demolition & $3.40 \%$ \\
\hline
\end{tabular}

Sa et al. (2009) concluded that a greater proportion of commercial roofers consider their sites safe, as compared to the residential roofers, as $97 \%$ of the commercial roofers responded that their companies had fall protection programs, whereas only $58 \%$ of the residential roofers replied that their companies had fall protection programs. A survey in Michigan roofing contractors also showed that only $28 \%$ of the companies have established safety programs, and only larger companies opted for safe work practices (Fredericks, Abudayyeh, \& Choi, 2005). The role of management in the enforcement of safe work practices in commercial roofers was found to be two times more as compared to the residential roofers, showing poor level of awareness in the residential roofing sector. Johnson et al. (1998) also reported that the state of compliance to regulations and standards was extremely poor making residential roofing industry of Hawaii more exposed to fall accidents. 
Therefore, it is inferable from the literature review that new projects that may involve the construction of residential housing and commercial building projects are subjected to an increased risk of fall hazards, as compared to other types of projects (Huang and Hinze, 2003).

\subsubsection{Fall Accidents by Size of Project and Size of Company}

Size of the project is the descriptive parameter and, it has been addressed by various researchers in different ways. Cost of project is considered to be the principal parameter to identify the size of the project. Big companies usually do not associate themselves with lower budget projects, as they would ultimately end up losing their money due to high overheads and lesser financial liquidity. Therefore, it can be safely ascertained that majority of the low budget projects are executed by small contractors. Table $2-5$ shows the percentage of fall accidents with respect to the project budget as noted by Huang and Hinze (2003). It was found that $28 \%$ of the fall accidents occurred on projects with costs $\leq \$ 50,000$. Moreover, low-cost projects $(\leq \$ 250,000)$ were responsible for half of the fall accidents in the U.S. construction industry.

Table 2-5: Falls with respect to project budget by Huang and Hinze (2003)

\begin{tabular}{|c|c|}
\hline Project Budget & Huang and Hinze (2003) \\
\hline Under $\$ 50,000$ & $28.10 \%$ \\
\hline Between $\$ 50,000$ to $\$ 250,000$ & $18.80 \%$ \\
\hline Between $\$ 250,000$ to $\$ 500,000$ & $9.80 \%$ \\
\hline $\begin{array}{c}\text { Between } \$ 500,000 \text { to } \\
\$ 10,00,000\end{array}$ & $11 \%$ \\
\hline $\begin{array}{c}\text { Between } \$ 10, \text { oo, ooo to } \\
\$ 50,00,000\end{array}$ & $15.50 \%$ \\
\hline $\begin{array}{c}\text { Between } \$ 50,00,000 \text { to } \\
\$ 20,000,000\end{array}$ & $9.60 \%$ \\
\hline Between $\$ 20,000,000$ and over & $6.80 \%$ \\
\hline
\end{tabular}


Sa et al. (2009) determined that smaller companies have a bad safety record, as compared to the big companies. The researchers have advised that small companies should pay more attention to fall protection and prevention systems, and they should make every effort to educate their workforce. It is apparent from the literature review that the residential construction sector is at a higher risk to occupational injuries and fatalities, due to lack of training and education that can be due to their limited finances and inability to enforce and promote safe work practices.

The size of the company and workers' experience are important factors leading to fall accidents. Dong et al. (2009) found that small construction companies are creating a problem in terms of safety in the U.S. construction industry. They have less manpower and resources, and their manpower is not usually trained. The researchers suggested that clients' should also play their role while selecting such contractors. General contractors should make sure that their sub-contractors are taking all the necessary steps to promote safe work practices. The study was concluded with an advice to OSHA, that more targeted inspections should be planned for small companies, so that there would be greater compliance. This study confirmed that with the positive enforcement of safe work practices and use of fall protection equipment the number of accidents could be reduced.

The role of subcontractors cannot be neglected in the construction industry, as they usually perform $80 \%-90 \%$ of the work on many construction projects (Olbina et al., 2011). Sub-contractors usually are small business entities with limited resources and, they generally have below par safety performance. The researchers have advised that general contractors must take steps to train their subs, as many general contractors do not 
provide safety training to their sub-contractors since they expect them to be responsible for their own safety. Olbina et al. (2011) also found that large companies have better performance in terms of safety as compared to the small companies.

\subsubsection{Fall Accidents by Trades/ Professional Categories}

The three standard industrial classification categories of the construction industry consist of various trade categories. There are certain trades (e.g. roofing, siding and sheet metal works, carpentry works, etc.) which are more vulnerable to fall accidents. Table 26 presents a comparison of fall accidents with respect to fall susceptible trade categories as noted by previous studies. "Roofing, siding and sheet metal work" was found to be the leading trade experiencing fall accidents as recorded by many previous studies (Bobick, 2004; Hatipkarasulu, 2010; Huang \& Hinze, 2003; Saruda et al., 1995). Other trades that are more vulnerable to falls include structural steel erection works and carpentry works. Due to high injury and incidence rate particularly in the roofing industry, the workers' compensation and insurance premiums are increasing, which is a growing concern for the companies in the business of roofing, siding and sheet metal works (Choi, Fredericks, Abudayyeh, \& Keslinke, 2003). 
Table 2-6: Falls with respect to different trades as noted by previous studies

\begin{tabular}{|c|c|c|c|c|}
\hline $\begin{array}{c}\text { Trade } \\
\text { Category }\end{array}$ & $\begin{array}{c}\text { Saruda et al. } \\
\text { (1995) (only } \\
\text { roof fall } \\
\text { fatalities } \\
\text { considered) }\end{array}$ & $\begin{array}{c}\text { Huang and } \\
\text { Hinze (2003) }\end{array}$ & $\begin{array}{c}\text { Bobick } \\
\text { (2004)(only } \\
\text { fatalities } \\
\text { considered) }\end{array}$ & $\begin{array}{c}\text { Hatipkarasulu } \\
\text { (2010) (only } \\
\text { fatal } \\
\text { accidents) }\end{array}$ \\
\hline $\begin{array}{c}\text { Roofing, } \\
\text { Siding, and } \\
\text { Sheet Metal } \\
\text { Work }\end{array}$ & $44.80 \%$ & $21.63 \%$ & $18.77 \%$ & $27 \%$ \\
\hline $\begin{array}{c}\text { Structural } \\
\text { Steel } \\
\text { Erection } \\
\text { Works }\end{array}$ & $11.60 \%$ & $8.50 \%$ & $10.52 \%$ & $9.94 \%$ \\
\hline $\begin{array}{c}\text { Carpentry } \\
\text { Works }\end{array}$ & -- & $7.64 \%$ & $6.10 \%$ & $8.28 \%$ \\
\hline $\begin{array}{c}\text { Painting } \\
\text { Works }\end{array}$ & -- & $3.69 \%$ & $6.60 \%$ & $6.60 \%$ \\
\hline $\begin{array}{c}\text { Masonry, } \\
\text { stone work, } \\
\text { tile setting } \\
\text { and } \\
\text { plastering }\end{array}$ & - & -- & $7.30 \%$ & $7.70 \%$ \\
\hline
\end{tabular}

\subsubsection{Fall Accidents with respect to Fall Type/ Cause}

There have been a number of studies investigating different dimensions about fall accidents in the U.S. construction industry. There can be different physical causal factors that may lead to a fall accident. Table 2-7 lists several physical causal factors leading to fall accidents, as noted by Huang and Hinze (2003). It was found that operations at roofs, 
structures, ladders and scaffolds make up the majority of fall hazards. Falls from the roofs was found to be the leading cause of fall accidents.

Table 2-7: Causes of fall accidents by Huang and Hinze (2003)

\begin{tabular}{|c|c|}
\hline Major Causes of Falls & $\begin{array}{c}\text { Huang and } \\
\text { Hinze } \\
\text { (2003) }\end{array}$ \\
\hline Falls from the roof & $28.36 \%$ \\
\hline Falls from/with ladder & $11.33 \%$ \\
\hline $\begin{array}{l}\text { Falls from/ with scaffold } \\
\text { staging }\end{array}$ & $13.03 \%$ \\
\hline Falls from/ with structure & $19.34 \%$ \\
\hline Falls through opening & $7.67 \%$ \\
\hline $\begin{array}{c}\text { Falls from/with bucket } \\
\text { (aerial lift/ basket) }\end{array}$ & $3.15 \%$ \\
\hline $\begin{array}{l}\text { Falls from/ with platform } \\
\text { catwalk }\end{array}$ & $2.39 \%$ \\
\hline $\begin{array}{l}\text { Fall from vehicle (vehicle/ } \\
\text { construction equipment) }\end{array}$ & $2.30 \%$ \\
\hline
\end{tabular}

Falls from the roofs are found to be the most frequent and recurring incident amongst all types of falls in the U.S. construction industry (Huang \& Hinze, 2003; Sa et al., 2009). The roofing works primarily include installation of roofing, siding and sheet metal work on residential and commercial projects. Therefore, due to the nature of work performed by the roofers, roofing is considered to be one of the most dangerous professions of the construction industry. The probability of roofers sustaining injury due to fall is more than other workers', as the NIOSH (2004) reported that the incidence rate of non-fatal 
occupational injuries for roofing workers were $1.1-1.8$ times higher than other types of construction workers in general from 1992 to 2001. According to U.S. BLS (2010), the roofing workers are three times more likely to receive fatal injuries, than other workers in the construction industry and the primary cause of the accident is fall. The two major sectors of the roofing industry are the residential roofing and commercial roofing works. Residential roofers are the ones who are more exposed to the fall hazards and are subjected to greater accidents and injuries, as compared to the commercial roofers, mainly due to lack of education, training and awareness about the safety practices in construction (Sa et al., 2009).

\subsubsection{Fall Accidents with respect to Fall Height}

Height of fall is a very interesting and important parameter that has been widely studied by various researchers. Table 2-8 presents the trend of fall accidents at different height intervals as noted by previous researchers. Huang and Hinze (2003) proposed that special attention should be given to the works executed at or less than $30 \mathrm{ft}$., since they

found that most of the falls occur at such heights. Suruda et al. (1995) concluded from their study that more than thirty percent of the fatal falls occurred on heights less than or equal to $30 \mathrm{ft}$. They have advised the regulators to take steps to ensure the enforcement of fall protection measures at such specific heights. 
Table 2-8: Falls heights by Huang and Hinze (2003) and Saruda et al. (1995)

\begin{tabular}{|c|c|c|}
\hline $\begin{array}{c}\text { Height of Fall } \\
\text { (ft.) }\end{array}$ & $\begin{array}{c}\text { Huang and } \\
\text { Hinze } \\
\text { (2003) }\end{array}$ & $\begin{array}{c}\text { Saruda et al. } \\
\text { (1995) - (only } \\
\text { rooffall } \\
\text { fatalities } \\
\text { considered) }\end{array}$ \\
\hline $0-10 \mathrm{ft.}$ & $23 \%$ & $2.70 \%$ \\
\hline $10-20 \mathrm{ft.}$ & $28 \%$ & $23.60 \%$ \\
\hline $20-30 \mathrm{ft.}$ & $22 \%$ & $39.10 \%$ \\
\hline $30-40 \mathrm{ft.}$ & $8 \%$ & $14.18 \%$ \\
\hline $40-50 \mathrm{ft.}$ & $5 \%$ & $6.7 \%$ \\
\hline $50-60 \mathrm{ft.}$ & $2.5 \%$ & $6.7 \%$ \\
\hline$>60 \mathrm{ft.}$ & $11.5 \%$ & $7.02 \%$ \\
\hline
\end{tabular}

Sa et al. (2009) conducted a survey and noted that, the average working height in case of commercial roofers was reported to be more than 26 feet, whereas residential roofers generally work on heights ranging between 11-15 feet. Therefore, Sa et al. (2009) has concluded that falls from roofs are anticipated to happen at short heights (20 feet or less), and the probability of occurrence of an accident at such heights is much more.

\subsubsection{Fall Protection}

There has been a group of studies investigating the impact of fall protection devices on fall accidents, but there is hardly any study conducted in the past that specifically addressed the state of usage of fall protection using actual accident data (OSHA's IMIS database). Almost all the occupational injuries in the construction industry are avoidable through actions including "strengthened safety regulations," "safety training," "better 
planning and engineering controls," and, "knowledge and cooperation among industry stakeholders" (Hatipkarasulu, 2010). Absence of fall protection has been identified as the most recognized cause of fatal falls in many studies (Beavers et al., 2009; Janicak, 1998; Suruda et al., 1995).

Hung et al. (2012) studied training needs for the residential roofing contractors by conducting interviews of some selected roofing companies working in the residential roofing sector. As per the response from the participants, the main obstacle to safety training was influenced by workers feeling sufficiently knowledgeable. Workers' perspective that, risk of falls is manageable and controllable might have led to poor safety education among the participants. Inconsistent employment roles were also recognized as an obstacle to safety training. The researchers have advised that fall protection training should mainly emphasize on enhancing workers' understanding of safe work practices. This study also identified the shortcomings of formal safety training programs and pointed out a gap between safety training and actual work practices, which have considerably damaged trainers' credibility in the perspective of the workers being trained. Therefore, coupled with formal safety training, there is a need of on-site informal safety training, as well. On-site practical training will enable the workers to practically understand the usage of fall protection devices.

Beavers et al. (2009) reported that "lack of fall protection" and "misuse of fall protection" were the leading contributing factors for falls resulting from structural steel erection works. This study has also pointed out the situations when the workers tend to unhook their fall protection in order to relax or change their locations, and that was the 
instant when the accident happened. The researchers emphasized the need of increased efforts in training and awareness about the usage of fall protection in the structural steel erection trade, as there are a good number of persons using it. However, they are being used in the wrong manner.

Janicak (1998) studied fall related deaths and concluded that the lack of fall protection equipment was the leading cause of fatal falls. Moreover, it was noted that, at greater heights, the trend of usage of fall protection was more as compared to lower heights. The research concluded with the recommendation that following major areas should be taken care of: "prevention activities should include employee training," "enforcement of use of fall protection systems," and, "inspection and testing of fall protection in use".

Table 2-9 shows the trend of usage of fall protection, as noted by previous studies. Huang \& Hinze, (2003) concluded in their study that lack of safety training is a contributing factor for most of the fall accidents. Providing adequate fall protection equipment and training to the employees can reduce the number of falls. Inadequate and inappropriate use of personal protective equipment (PPE) has contributed to more than $30 \%$ of the falls. Moreover, they have advised the authorities to devise innovative training methodologies, as conventional training methods are not working in an efficient way to reduce the falls. 
Table 2-9: Fall protection usage as noted by previous studies

\begin{tabular}{|c|c|c|c|}
\hline $\begin{array}{c}\text { Fall } \\
\text { Protection }\end{array}$ & $\begin{array}{c}\text { Beavers et } \\
\text { al. (2009 } \\
\text { (only steel } \\
\text { erection } \\
\text { accidents) }\end{array}$ & $\begin{array}{c}\text { Janicak } \\
\text { (1998) (only } \\
\text { fatalities } \\
\text { considered) }\end{array}$ & $\begin{array}{c}\text { Huang and } \\
\text { Hinze } \\
\text { (2003) }\end{array}$ \\
\hline $\begin{array}{c}\text { Lack of } \\
\text { Fall } \\
\text { Protection }\end{array}$ & $38.80 \%$ & $35.30 \%$ & -- \\
\hline $\begin{array}{c}\text { Misuse of } \\
\text { Fall } \\
\text { Protection }\end{array}$ & $43.30 \%$ & $10.00 \%$ & $30.00 \%$ \\
\hline
\end{tabular}

Olbina et al. (2011) found that better safety is observed when following tasks are taken up: "workers use PPE," "pre task planning is conducted on job sites," "project specific safety plans are made," and "toolbox meetings are regularly conducted on site". It was found that the job sites where safety directors spend more time have better performance, as compared to the job sites where the safety directors spend less time. This refers to the management commitment in regards to promoting and enforcing safety culture on site. This study also addressed the effectiveness of safety training and education. They found that the companies that have more training hours have better results in terms of the injury rate, as compared to the companies with fewer training hours.

Johnson et al. (1998) investigated the trend of usage of fall protection systems, behaviors and attitudes of workers in the residential roofing industry of Hawaii. It was noted that there was severe noncompliance to the standards, which could be due to the following: "lack of training and education," "due to high competition and the need of 
increased productivity safety practices were being compromised," and "worker behavior in regards to increased productivity and their comfort".

Suruda et al. (1995) found that lack of PPE, was the leading factor contributing to fatal falls. They also highlighted the importance of role of supervisors on site for the enforcement of fall protection measures and general safety. They conducted a survey of low and high end roofing contractors and found that most of the roofers consider their foreman as the main person responsible for their safety.

$\mathrm{Hu}$ et al. (2011) found that "workers safety behavior and attitudes" (e.g. safety procedure, perceived risks, evaluation of risk, operation at unsafe speed, etc.) is one of the very strongly supported arguments that exists in literature in regards to the leading risk of falls and injuries. The other greatly researched and constantly identified factors that contribute to the risk of falls includes: "the safety behavior at the contractor/ managerial level," "the use of PPE and methods," "the workers' health and physical characteristics," "environment at the construction site," "size of construction company," and "height of workplace".

\subsubsection{Nature of Injury}

There can be multiple types of injuries that may be experienced by the victim of a fall accident, but fractures are the most recurrent and common injury that is incurred to the victims' of fall accidents. Bobick (2004) calculated the dollar value of a single fracture (as of the year 1998). Conservatively, the cost of a single fracture was estimated to be around $\$ 55,382$. It should be noted that this estimate was the most conservative, as the 
direct and indirect costs were considered to be equal. However, a study conducted by CII argued that the indirect cost can go up to twenty times the direct cost, when legal costs are included (ENR 1990). Thus, it is pretty clear that a single fracture can easily cause a small company to go out of business, and it also spells out the importance of enforcement of fall protection and safety regulations.

\subsection{OSH Act and OSHA's Fall Protection Regulations}

As per the general duty clause of the Occupational Safety and Health Act, "Each employer shall furnish to each of his employees employment and a place of employment which are free from recognized hazards that are causing or likely to cause death or serious physical harm to employees". The general duty clause of OSHA is applicable in every situation.

OSHA's general fall protection standard for the construction industry is as follows: As per 29 CFR 1926.501 (b) (1), Unprotected sides and edges, "Each employee on a walking/working surface (horizontal and vertical surface) with an unprotected side or edge which is 6 feet $(1.8 \mathrm{~m})$ or more above a lower level shall be protected from falling by the use of guardrail systems, safety net systems, or personal fall arrest systems."

OSHA has stipulated different fall protection requirements in case of structural steel erection works. As per 29 CFR 1926.760.(a).(1), "Each employee engaged in a steel erection activity who is on a walking/working surface with an unprotected side or edge more than 15 feet $(4.6 \mathrm{~m})$ above a lower level shall be protected from fall hazards by guardrail systems, safety net systems, personal fall arrest systems, positioning device 
systems or fall restraint systems". Above 30ft. / 2 stories all workers must be protected including the connectors [29 CFR 1926.760.(b)./(1)]. At working heights over $15 \mathrm{ft}$. up to $30 \mathrm{ft}$., connectors must be provided with a complete fall arrest system or other allowable fall protection and wear the equipment necessary for tying off [ 29 CFR 1926.760.(b)(3)]. "Deckers working in between $15 \mathrm{ft}$. and $30 \mathrm{ft}$./ 2 stories can use a control decking zone, instead of fall protection. Access of control decking zone will be limited to those workers who are involved in leading edge work" [29 CFR 1926.760.(c)].

\subsection{Problem Statement}

Falls are the major cause of injuries and fatalities in the U.S. construction industry. Although there is a gradual decline observed in the work related injuries and fatalities in construction industry, fall accidents didn't experience any considerable improvement. While there have been many studies investigating the fall accidents, the current body of knowledge lacked a recent analysis on the causes of fall accidents by examining the latest available dataset. There was a gap noted in the literature, especially in the past decade, as there was hardly any work done to investigate fall accidents, specifically using actual accident investigation data (IMIS database). The last major study that analyzed IMIS database for studying fall accidents was done by Huang and Hinze (2003), which used the data from 1997-2001 involving 1,215 accidents. Other previous studies were simply based on surveys or interviews, which represented a particular group of people for more specific topics. Some studies on the other hand, just focused on fatal or serious accidents resulting due to falls. Therefore, there was an immense need of a study analyzing fall accidents by utilizing the latest dataset; as the rising trend of fall accidents 
calls for urgent attention. In contrast to previous research, this study has analyzed comparably larger dataset; as such a big sample size may not have been analyzed previously by any research study studying fall accidents. Thus, this study presents updated causal factors, trends and dimensions about fall accidents in the U.S. construction industry. 


\section{CHAPTER 3: RESEARCH METHODOLOGY}

\subsection{Introduction}

This study examines various characteristics of fall accidents, which are classified into three parts: industry type, project type and size, and dimensions of fall accidents, in terms of fall cause, fall height, and trend of usage of fall protection. Therefore, in order to conduct this study, acquisition of the data set of accidents was of prime importance. As without it, there was no way in proceeding with the in-depth analysis of particular parameters associated with falls in the U.S. construction industry.

This study investigates the OSHA's IMIS database for all the recorded fall accidents from 1994 to 2013. There were a total of 21, 058 recorded accidents, out of which 9,399 were categorized as falls (from elevation as well as the same level). The total numbers of victims were 23,875 and out of them 10,198 were involved in fall accidents.

Fig 3-1 illustrates the flowchart of this research study. In the first phase of the literature review, papers were reviewed in regards to safety in general which led, to the identification of falls as the major contributor of accidents in the U.S. construction industry. OSHA's fall protection policy and standards were also reviewed in this first phase. The literature review concluded with a finding that there was hardly any study done in the last decade to study about fall accidents by specifically examining the IMIS dataset. In the second phase, fall accident data was acquired from OSHA. The data was processed, filtered and coded for fall height, fall cause and fall protection. In the analysis phase, fall accidents were investigated with respect to industry type, project 
characteristics, fall cause, fall height and fall protection. As a result of the analysis, updated findings about fall accidents in the U.S. construction industry were produced, and changing trends were also reported, when the results were compared to similar previous studies. Following the analysis phase, a discussion is made in the light of reported findings and changing trends in order to draw a conclusion for this research study.

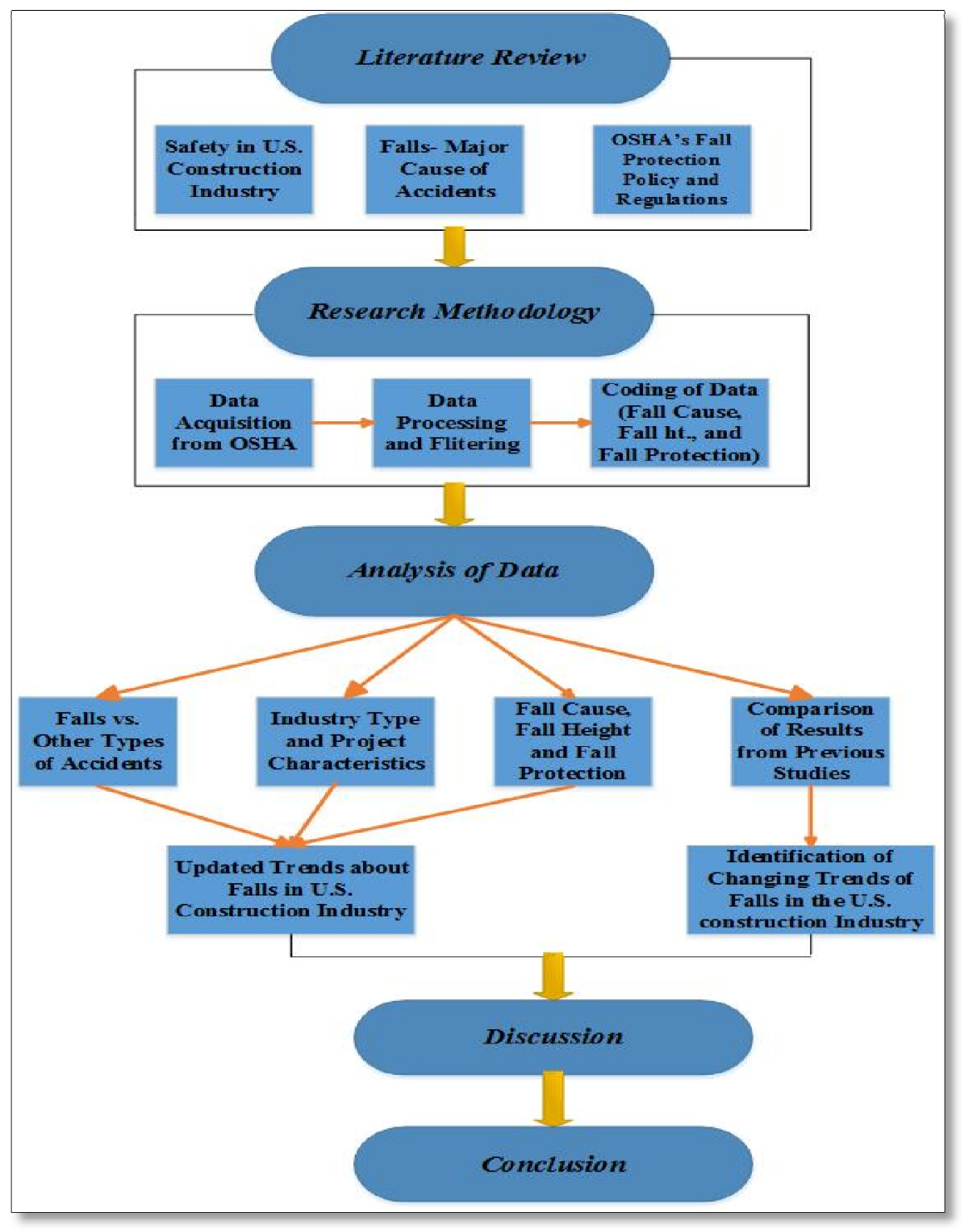

Figure 3-1: Flowchart of this research study 


\subsection{Data Acquisition from OSHA}

OSHA records all recordable accidents and injuries in a database known as Integrated Management Information System (IMIS), which is also accessible online on OSHA's website. The reason online database could not be used for this study is that, the online data is not available in a user friendly format, and it was not practically possible to copy all the case reports and manually organize them in a data management and processing software like Microsoft Excel. Therefore, a request was made under the Freedom of Information Act to OSHA for the release of the IMIS database for fall accidents (in a user friendly format, e.g. MS Excel), which contains all the details of accidents recorded by OSHA. The request was successfully granted approval, and they provided OSHA's IMIS database in Microsoft Excel format.

\subsection{Data Processing and Filtering}

The data set provided by OSHA was in a random state, meaning that it could not be used for the analysis in its original form. Moreover, OSHA provided the complete IMIS database, which contained every recorded accident that occurred in the U.S. construction industry, in the past two decades. There were different data processing techniques taken up to filter and reform the provided data set into a form, which can be used for the analysis.

The excel file of the IMIS data set contained two tabs; the first tab (Fig 3-2) had all the details about the accident except the accident description, which was in the second tab of the same file. In the second tab, the accident description was organized in such a way 
that the summary of an accident was recorded in multiple rows (Fig 3-3). Since an accident may have more than one victim, the details for cases involving multiple victims were recorded in multiple cells, in the first tab, so all those cases were manually processed in such a way that the end result would be one accident per row with all its details (Fig 3-4). In the second tab, data is processed to organize all the multiple line summaries into one single row per case (Fig 3-5). After doing these tasks separately in two tabs; the accident summaries were gradually copied from the second tab to the first tab (Fig 3-6) so that they could match their respective cases and a single Excel file may have every detail about the accident (the desired end result is to get one accident per one single row). In the final step, new parameters i.e., fall cause, fall height and fall protection were coded, and victim specific details of the accidents were sorted. If the case had more than one victim, then the data is so arranged that victim-specific details such as fall cause, fall height, injury type, etc., were recorded separately in multiple rows, but accident summary rows were combined into a single cell to represent one case (Fig 3-7). The data is so organized that the number of cases can be counted by counting the accident investigation summary cells. The number of victims for each case could be different, but they are tied to their summaries that are present in a single combined row. Therefore, number of cases and number of victims can be counted and filtered as per the need of the analysis. A Microsoft Excel add-on "kutools" was extensively used during the data processing and filtering phase.

In the above described way, the whole IMIS dataset was processed and refined into one single file. This file could be used for any other study, as well other than fall 
accidents, since it contains a well-organized database for every accident that occurred in the U.S. construction industry from 1987 to 2013.

After data processing a filter, was applied to the event type column, for "falls from elevation" and "falls from the same level," in order to isolate fall related cases from the IMIS dataset. Then all the hidden rows were deleted in order to obtain a file containing only fall-related cases from the IMIS database, which ultimately filtered out 9,399 recorded fall accidents involving 9,876 victims.

\begin{tabular}{|c|c|c|c|c|c|c|c|c|c|c|c|c|}
\hline summ nr & rid & open date & event date & establishment & sic & naics & street & city & state & zip & hazsub & keywords \\
\hline & & & & & & & $16 \mathrm{ELM}$ & & & & & $\begin{array}{l}\text { CONSTRUCTION } \\
\text { ELECTRICAL } \\
\text { OVERHEAD POWER LINE } \\
\text { STRUCKAGAINST } \\
\text { LADDER } \\
\text { ELECTROCUTED } \\
\text { CLEARANCE } \\
\text { INATEENTION WORK }\end{array}$ \\
\hline 202220315 & 111100 & 20030701 & 20030701 & COLLEGE PRO PAINTERS & 1721 & 238320 & STREET & Topsham & M5 & 4086 & & RULLES PAINTER \\
\hline 202220057 & 111100 & 19970501 & 19970327 & $\begin{array}{l}\text { HARRASEEKET ROOFING \& } \\
\text { RESTORAT }\end{array}$ & 1761 & & $\begin{array}{l}\text { BERWICK } \\
\text { ACADEMY }\end{array}$ & $\begin{array}{l}\text { South } \\
\text { Berwick }\end{array}$ & M5 & 3909 & & $\begin{array}{l}\text { LADDER FALL } \\
\text { EXTENSION LADDER }\end{array}$ \\
\hline 202220166 & 111100 & 19990126 & 19990125 & $\begin{array}{l}\text { LONEMAPLE } \\
\text { CONSTRUCTION }\end{array}$ & 1542 & & $\begin{array}{l}\text { PORT CLYDE } \\
\text { HARBOR }\end{array}$ & Port Clyde & M5 & 4855 & & $\begin{array}{l}\text { DROWN BOAT } \\
\text { OVERTURN }\end{array}$ \\
\hline 202220166 & 111100 & 19990126 & 19990125 & $\begin{array}{l}\text { LONEMAPLE } \\
\text { CONSTRUCTION }\end{array}$ & 1542 & & $\begin{array}{l}\text { PORT CLYDE } \\
\text { HARBOR }\end{array}$ & Port Clyde & M5 & 4855 & & $\begin{array}{l}\text { DROWN BOAT } \\
\text { OVERTURN }\end{array}$ \\
\hline 202220224 & 111100 & 20011016 & 20011016 & S\& J ROOFING & 1761 & & $\begin{array}{l}\text { G3 GRANT } \\
\text { STREET }\end{array}$ & Portland & M5 & 4102 & & $\begin{array}{l}\text { CONSTRUCTION } \\
\text { ROOFER ROOF } \\
\text { SLOPE FALL } \\
\text { FALIPROTECTION WORK } \\
\text { RULES UNSTABLE } \\
\text { FOSITION }\end{array}$ \\
\hline 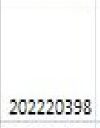 & 111100 & 20031204 & 20031204 & $\begin{array}{l}\text { PORTLAND TUG BOAT, } \\
\text { LIC }\end{array}$ & 1799 & 238990 & $\begin{array}{l}\text { MAINE } \\
\text { STATE, PIER } 2\end{array}$ & Portland & M5 & 4101 & & $\begin{array}{l}\text { CONSTRUCTION } \\
\text { CRUSHED } \\
\text { SOATE } \\
\text { STEEL } \\
\text { CHEEST }\end{array}$ \\
\hline 202220554 & 111100 & 20060809 & 20060809 & $\begin{array}{l}\text { LV.ALLEN \& SON } \\
\text { EXCAVATION }\end{array}$ & 1629 & 237110 & $\begin{array}{l}295 \text { HARRY } \\
\text { HOWES } \\
\text { ROAD }\end{array}$ & Sanford & M5 & 4073 & & $\begin{array}{l}\text { STRUCKBY ABRASION } \\
\text { CONTUSION } \\
\text { EXPLOSION PRESSURE } \\
\text { RELEASE PRESSURE } \\
\text { VESSEL HEAD }\end{array}$ \\
\hline
\end{tabular}

Figure 3-2: Screenshot of OSHA's IMIS provided dataset (tab-1) 


\begin{tabular}{|c|c|c|c|}
\hline INSP NR & SUMM NR & LINE & DESCRIPTION \\
\hline 112802012 & 202220315 & & 1 On July 1,2003 , Employee $\# 1$, age 20, was painting a house. He was moving a ladd \\
\hline 112802012 & 202220315 & & 2 er when it contacted an overhead electric power line. Employee \#1 was electrocut \\
\hline 112802012 & 202220315 & & 3 ed. \\
\hline 117907113 & 202220067 & & 1 Employee \#1 climbed a 40-foot extension ladder while carrying a five-gallon \\
\hline 117907113 & 202220067 & & 2 bucket full of tools. He fell off the ladder and was severely injured. Employee \\
\hline 117907113 & 202220067 & & 3 \#1 died eight days later. \\
\hline 112569322 & 202220166 & & 1 Employee \#1 and \#2 and two coworkers were aboard a small skiff when the boat was \\
\hline 112569322 & 202220166 & & 2 swamped by a wave and turned over. Employees \#1 and \#2 drowned. \\
\hline 117911677 & 202220224 & & 1 On October 16,2001 , Employee $\# 1$, a roofer, was working on a pitched roof when $\mathrm{h}$ \\
\hline 117911677 & 202220224 & & 2 e fell $35 \mathrm{ft}$ from the eave to the ground. He was transported by ambulance to the \\
\hline 117911677 & 202220224 & & 3 hospital, where he died at 5:30 a.m. the next day. Employee \#1 was not using an \\
\hline 117911677 & 202220224 & & 4 y form of fall protection. \\
\hline 112803655 & 202220398 & & 1 On December 4, 2003, Employee \#1 was struck to his chest by a steel rope on the \\
\hline 112803655 & 202220398 & & 2 tugboat. He was killed. \\
\hline 113790307 & 202220554 & & 1 On August 9, 2006, Employee \#1 was pressure cleaning equipment with a 300 pound \\
\hline 113790307 & 202220554 & & 2 tank with $10 \mathrm{psi}$. The end of the tank blew off, propelling its top 147 feet. Als \\
\hline 113790307 & 202220554 & & 3 o the metal bands holding the tank broke loose and struck Employee \#1. Employee \\
\hline 113790307 & 202220554 & & 4 \#1 suffered multiple bruises and abrasions. \\
\hline
\end{tabular}

Figure 3-3: Screenshot of OSHA's IMIS provided dataset (tab-2)

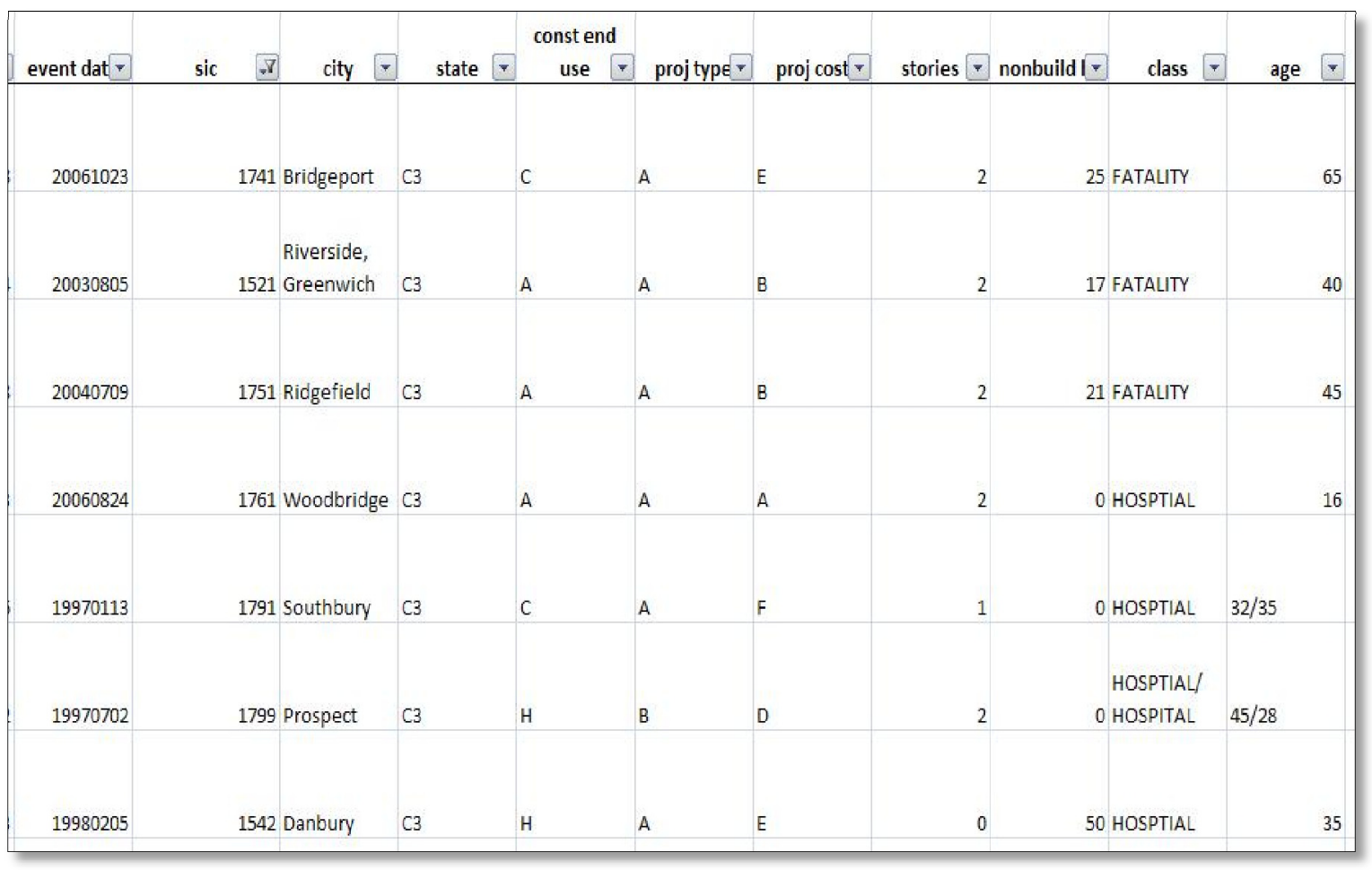

Figure 3-4: Screenshot of data processing step-1 (tab-1) 


\begin{tabular}{|c|c|c|c|}
\hline 304440167 & 202356556 & 7 & \\
\hline 304440175 & 202359808 & \multicolumn{2}{|r|}{1 At 9:00 a.m. on February 9, 2006, Employee \#1 was laying down on a 4-ft by 8- $\mathrm{ft}$ sheet of a fiber board on a flat roof. He $\mathrm{fe}$} \\
\hline 304440175 & 202359808 & 2 & \\
\hline 304440175 & 202359808 & 3 & \\
\hline 304440175 & 202359808 & 4 & \\
\hline 304440175 & 202359808 & 5 & \\
\hline 304140175 & 202359808 & 6 & \\
\hline 304440175 & 202359808 & 7 & \\
\hline 304140175 & 202359808 & 8 & \\
\hline 304440183 & 202359832 & \multicolumn{2}{|r|}{1 At approximately 1:15 p.m. on March 22, 2006, Employee \#1, a highway constructio n laborer who was wearing an orange } \\
\hline 304440183 & 202359832 & 2 & \\
\hline 304440183 & 202359832 & 3 & \\
\hline 304140183 & 202359832 & 4 & \\
\hline 304440183 & 202359832 & 5 & \\
\hline 304440183 & 202359832 & 6 & \\
\hline 310634282 & 202497764 & \multicolumn{2}{|r|}{1 On December 7, 2006, workers employed by a residential building contractor were installing windows on the third floor } \\
\hline 310634282 & 202497764 & 2 & \\
\hline 310634282 & 202497764 & 3 & \\
\hline 310634282 & 202497764 & 4 & \\
\hline 310634282 & 202497764 & 5 & \\
\hline 310634282 & 202497764 & 6 & \\
\hline 310634282 & 202497764 & 7 & \\
\hline
\end{tabular}

Figure 3-5: Screenshot of data processing step-1 (tab-2)

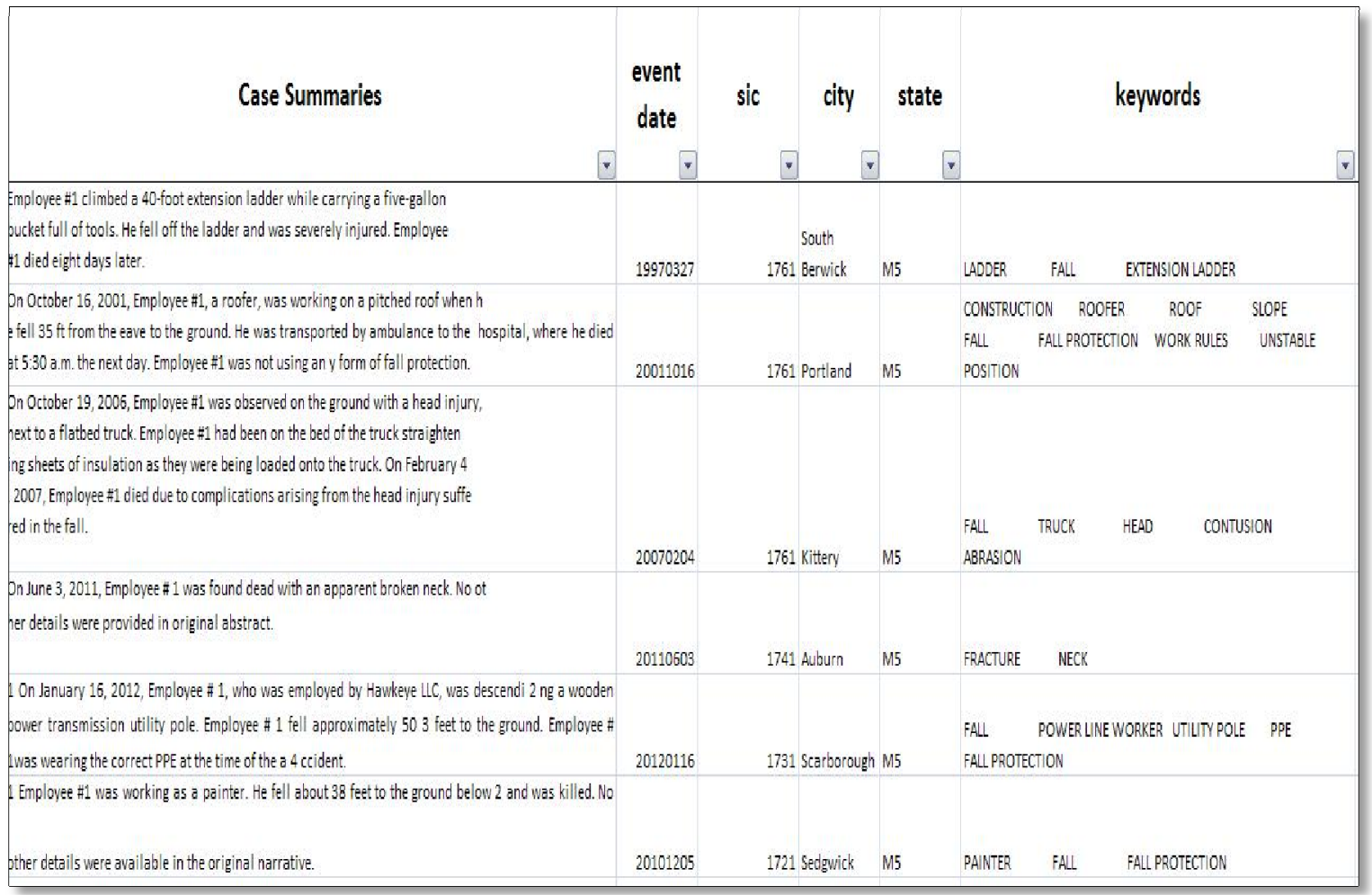

Figure 3-6: Screenshot of data processing step -2 


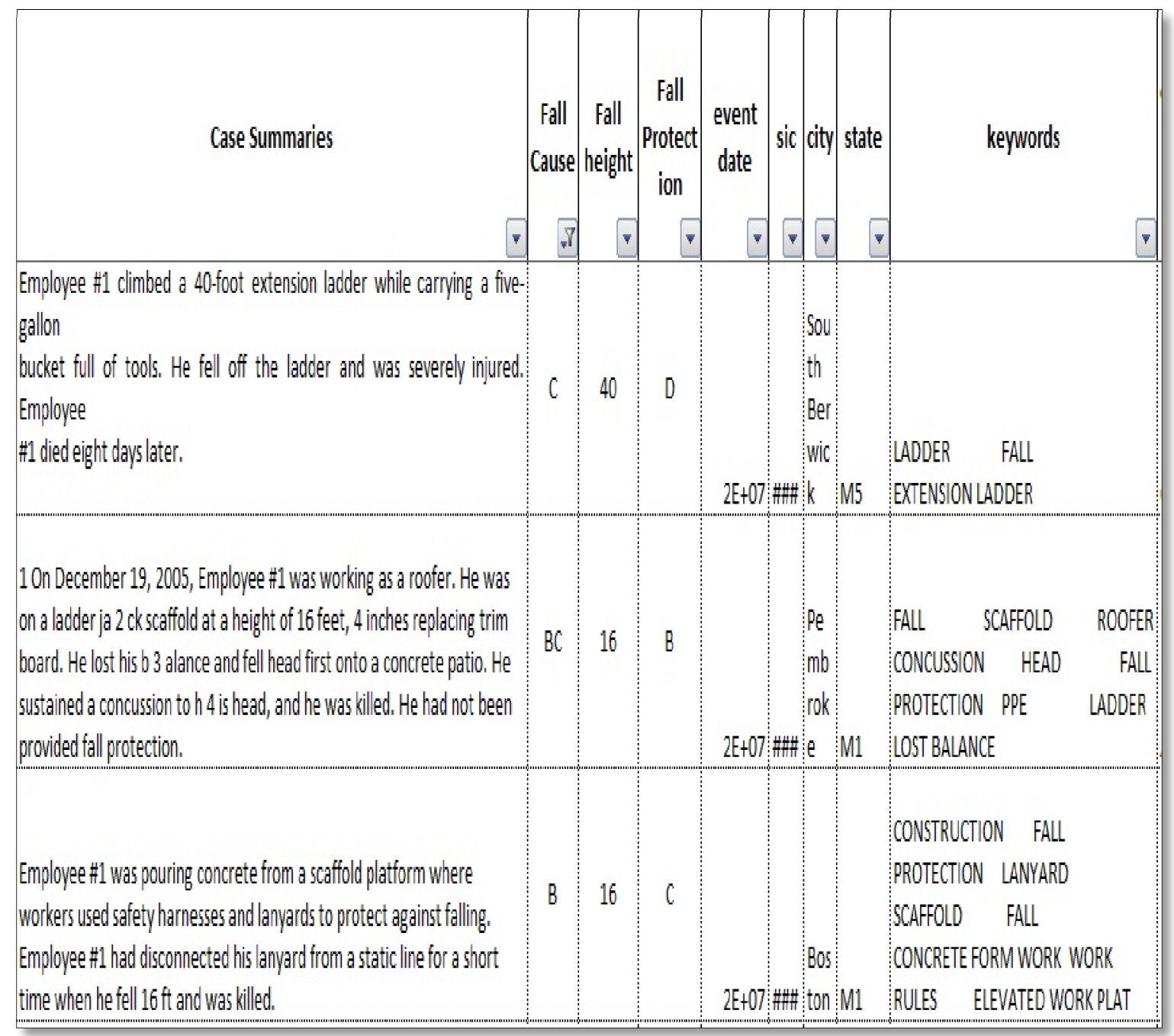

Figure 3-7: Screenshot of final data processing and coding phase (step-3)

\subsection{Parameters in the OSHA's IMIS Database}

Table 3-1 illustrates the list of the parameters that were available in the provided OSHA’s IMIS database. 
Table 3-1: List of available parameters in the OSHA's IMIS database

\begin{tabular}{|c|c|c|}
\hline No. & Factor & Description \\
\hline 1 & Description & $\begin{array}{c}\text { Description contains the accident summary as recorded } \\
\text { by OSHA's personnel, and it contains the details of } \\
\text { what actually happened. }\end{array}$ \\
\hline 2 & SIC Code & Standard Industrial Classification Code \\
\hline 3 & Month & Month in which the accident occurred \\
\hline 4 & State & State in which the accident occurred \\
\hline 5 & $\begin{array}{l}\text { Construction } \\
\text { End Use }\end{array}$ & E.g. Commercial Building, Manufacturing Plant, etc. \\
\hline 6 & Project Type & $\begin{array}{l}\text { E.g. New Project or a New Addition, Alteration or } \\
\text { Rehabilitation, etc. }\end{array}$ \\
\hline 7 & Project Cost & $\begin{array}{l}\text { Project Budget, e.g. under } \$ 50,000 \text {, between } \$ 50,000 \text { - } \\
\$ 250,000 \text {, etc. }\end{array}$ \\
\hline 8 & $\begin{array}{l}\text { Class of } \\
\text { Accident }\end{array}$ & $\begin{array}{l}\text { E.g. Fatality, Hospitalized Injury, or a Non- } \\
\text { Hospitalization }\end{array}$ \\
\hline 9 & Age & Age (years) of the victim \\
\hline 10 & Sex & Male or a Female \\
\hline 11 & $\begin{array}{l}\text { Nature of } \\
\text { Injury }\end{array}$ & E.g. Amputation, Asphyxia, etc. \\
\hline
\end{tabular}

\subsection{Review of the Database and Coding of Additional Parameters}

After the data filtering and processing phase, the filtered 9,399 recorded fall accidents were thoroughly reviewed in order to extract information about following important dimensions: fall cause, fall height and fall protection. Upon a closer look of the accident investigation summaries, it was found that there were 258 cases that were wrongly coded as falls. Such cases were then coded as " $\mathrm{X}$ " and eliminated from the analysis. The same error of inconsistent coding of data by OSHA has also been identified in the previous studies (Hinze \& Russell, 1995; Suruda et al., 1995). Therefore, the total number of cases 
considered for analysis was 9,141 instead of 9,399. Moreover, it was found that details of fall height were available for 6,524 cases $(71 \%)$ and fall protection details were available for just 3,102 cases $(34 \%)$.

\subsection{Coding of New Parameters (Fall Cause, Fall Height and Fall Protection)}

Since OSHA's IMIS database didn't contain every required parameter, it was decided to extensively review all the fall-related cases and extract information about the following parameters: fall cause, fall height and fall protection. The parameters shown in Table 3-2 are of paramount importance for a study discussing fall accidents in the construction industry.

Table 3-2: List of the newly added parameters

\begin{tabular}{|c|c|c|}
\hline No. & Factor & Description \\
\hline 1 & Fall Cause & $\begin{array}{l}\text { E.g. Falls from roof, ladder, scaffold, } \\
\text { etc. }\end{array}$ \\
\hline 2 & Fall Protection & $\begin{array}{l}\text { Whether fall protection measures were } \\
\text { taken or not. }\end{array}$ \\
\hline 3 & Fall Height & Height of fall in feet. \\
\hline
\end{tabular}

There can be various physical causal factors that may lead to a falling accident. Table 3-3 illustrates the list of physical causal factors, which may result in a fall accident. 
Table 3-3: List of the coded fall causal parameters

\begin{tabular}{|c|c|c|}
\hline No. & Code & Description \\
\hline 1 & A & $\begin{array}{l}\text { Fall from the roof (including roof } \\
\text { opening and skylight falls) }\end{array}$ \\
\hline 2 & B & $\begin{array}{l}\text { Fall from/ with the scaffold including } \\
\text { scaffold staging }\end{array}$ \\
\hline 3 & $\mathrm{BC}$ & $\begin{array}{l}\text { Fall from a combination of ladder and } \\
\text { scaffold system (e.g. ladder jack } \\
\text { scaffold system) }\end{array}$ \\
\hline 4 & $\mathrm{C}$ & Fall from/ with the ladder \\
\hline 5 & $\mathrm{E}$ & Fall through opening (other than roof) \\
\hline 6 & $\mathrm{~F}$ & $\begin{array}{l}\text { Fall from/ with the structure (other than } \\
\text { roof) }\end{array}$ \\
\hline 7 & G & $\begin{array}{l}\text { Fall from/ with bucket (aerial lift/ } \\
\text { basket/etc.) }\end{array}$ \\
\hline 8 & $\mathrm{H}$ & $\begin{array}{l}\text { Fall from/ by vehicle \& construction } \\
\text { equipment }\end{array}$ \\
\hline 9 & I & $\begin{array}{l}\text { Fall from structural steel erection } \\
\text { works/ building girders/ iron works }\end{array}$ \\
\hline 10 & $\mathrm{~J}$ & Fall from/ with the truss \\
\hline 11 & $\mathrm{~K}$ & Fall from/ with platform, catwalk, etc. \\
\hline 12 & $\mathrm{~L}$ & Fall from/ with the staircase \\
\hline 13 & M & Other non-classified falls \\
\hline 14 & $\mathrm{~N}$ & Fall from special structures \\
\hline 15 & $\mathrm{P}$ & $\begin{array}{l}\text { Fall on the same level and Falls in } \\
\text { excavations, pits, manhole, etc. }\end{array}$ \\
\hline 16 & Q & Miscellaneous Other falls \\
\hline 17 & $\mathrm{X}$ & Not a fall. Wrong coding of accident. \\
\hline
\end{tabular}


For fall protection parameter, broadly three different codes (A, B and C) that addressed the presence, absence and misuse of fall protection were coded and considered for the analysis. There were a total of 3,102 cases which contained information about the usage of fall protection (Table 3-4). The code " $\mathrm{D}$ " is coded for the cases that do not provide any information whatsoever about the usage of fall protection and safety. Code "F" is coded for cases in which an accident occurred but conditions were found to be okay as per OSHA's regulations. There were 42 such cases; $88 \%$ of the cases were reported in California and most of the accidents occurred in structural steel erection and roofing works. Following is the example of a case that was coded "F", Example: "On October 8, 2010, an employee of XYZ Construction, Inc. was on a structural beam at a height of approximately 14 feet. He was helping to anchor and install another structural beam when the beam dislodged and the employee tried to stabilize it. The victim lost his balance and fell to the ground head-first. The employee passed away as a result. Fall protection was not required at the height from which the victim fell". The cases coded with codes "F" are not used in the analysis, as the information extracted from such cases could not be interpreted into the three principal codes defined to study the current state of usage of fall protection. 
Table 3-4: Details of parameters coded for fall protection

\begin{tabular}{|c|c|c|l|}
\hline$\underline{\text { No. }}$ & $\underline{\text { Code }}$ & $\underline{\text { Number of Cases }}$ & \multicolumn{1}{|c|}{ Description } \\
\hline 1 & A & 305 & Fall Protection is Present. \\
\hline 2 & B & 2258 & Fall Protection is Absent. \\
\hline 3 & C & 539 & $\begin{array}{l}\text { Misuse of Fall Protection (e.g. untied safety } \\
\text { harness). }\end{array}$ \\
\hline 4 & D & 5998 & $\begin{array}{l}\text { No information about Fall Protection } \\
\text { available in the Investigation Summary. }\end{array}$ \\
\hline 5 & F & 42 & $\begin{array}{l}\text { Accident occurred but the site conditions } \\
\text { were okay as per the OSHA regulations and } \\
\text { no violation was found. Most of the cases } \\
\text { were from California involving structural } \\
\text { steel erection works. }\end{array}$ \\
\hline
\end{tabular}

\subsection{Analysis Methodology}

The analysis for this research is done in two phases. In the first phase descriptive analysis is performed for the available parameters of the OSHA's IMIS database. Whereas, in the second stage some of the important parameters such fall height, fall protection, project type, etc. are combined and analyzed, in order to study several characteristics and influential factors of fall accidents under specific conditions.

\subsubsection{Descriptive Analysis}

In the first stage of analysis descriptive analysis was done in which, bar charts, histograms and pie charts are plotted based on the available 20 year dataset of fall 
accidents. The important parameters that were investigated in the descriptive analysis phase are listed in table 3-5.

Table 3-5: List of parameters analyzed in the descriptive analysis phase

\begin{tabular}{|c|c|c|}
\hline No. & Factor & Description \\
\hline 1 & Fall Cause & Fall Cause/ Type (falls from the roof, ladder, and scaffold, etc.) \\
\hline 2 & Fall Height & Height of Fall (ft.) \\
\hline 3 & Fall Protection & $\begin{array}{l}\text { Cases were coded about the Presence/ Absence/ or Misuse of Fall } \\
\text { Protection }\end{array}$ \\
\hline 4 & $\mathrm{SIC}$ & $\begin{array}{l}\text { Standard Industrial Classification Code (SIC-15 ‘General Building } \\
\text { Construction', SIC-16 'Heavy Civil Works', SIC-17 'Specialty } \\
\text { Trade Contractors' }\end{array}$ \\
\hline 5 & $\begin{array}{l}\text { Construction End } \\
\text { Use }\end{array}$ & E.g. Commercial Building, Manufacturing Plant, etc. \\
\hline 6 & Project Type & $\begin{array}{l}\text { E.g. New Project or a New Addition, Alteration or Rehabilitation, } \\
\text { etc. }\end{array}$ \\
\hline 7 & Project Cost & $\begin{array}{l}\text { Project Budget, e.g. under } \$ 50,000 \text {, between } \$ 50,000-\$ 250,000 \text {, } \\
\text { etc. }\end{array}$ \\
\hline 8 & $\begin{array}{l}\text { Class of } \\
\text { Accident }\end{array}$ & E.g. Fatality, Hospitalized Injury, or a Non-Hospitalization \\
\hline 9 & Nature of Injury & E.g. Fractures, Amputation, Asphyxia, etc. \\
\hline
\end{tabular}

\subsubsection{Combined Analysis}

In the second phase of the analysis, combined analysis was performed; in which parameters such as fall height, fall protection, project type, etc. were combined and analyzed in order to observe the characteristics of falls in specific conditions. For example fall height and fall protection were combined and analyzed simultaneously, in order to investigate the current state of usage of fall protection at different height intervals. 


\subsubsection{Analysis by Number of Accidents and Number of Victims}

An accident may involve more than one victim. There were a total of 9,141 fall accidents involving 9,876 victims. Analysis of fall accidents with respect to industry type, project type and size, were done in regards to the number of accidents. These parameters are accident specific and would be same even if the accident has multiple victims. The dimensions of fall accidents such as fall heights, fall cause and fall protection were analyzed with respect to the number of victims. These parameters are victim specific and may vary from victim to victim in a particular accident. 


\section{CHAPTER 4: ANALYSIS}

The analysis is done in two stages for this research study. In the first stage, descriptive analysis was done on the dataset. Whereas, in the second stage, combined analysis was performed. In this chapter important trends and dimensions related to fall accidents, will be presented.

As discussed in the literature review, there has been a similar study done by Huang and Hinze (2003) regarding falls in the U.S. construction industry. This research study addressed similar dimensions as done by Huang and Hinze (2003), but with an updated dataset. Therefore, the results of the analyzed parameters are directly compared to Huang and Hinze (2003), in order to present updated trends and highlight any changing trends noted in regards to fall accidents.

This chapter is organized in such a way that the first section (4.1), presents the current state of fall accidents and, then falls are compared to other major types of accidents (such as struck by, caught in/ between, etc.). The first section also analyzes the severity of falls with respect to the nature of an injury incurred to the victim. Section 4.2 present's analysis of fall accidents with respect to industry type (SIC) and project characteristics (construction end use, type of construction and size of the project). In section 4.3, dimensions of fall accidents are analyzed with respect to fall cause, fall height and trend of usage of fall protection. 


\subsection{Comparison of Fall Accidents with other Major Types of Accidents}

Fig 4-1 illustrates the percentage of major types of accidents that occurred in the U.S. construction industry in the past two decades. Falls were found to be the leading cause of accidents, as they contributed to nearly half of the accidents. This finding also highlights the severity of the problem of fall accidents and their persistence in terms of higher incidence rate. The reason for falls being top the list of OSHA's fatal four is its higher incidence rate.

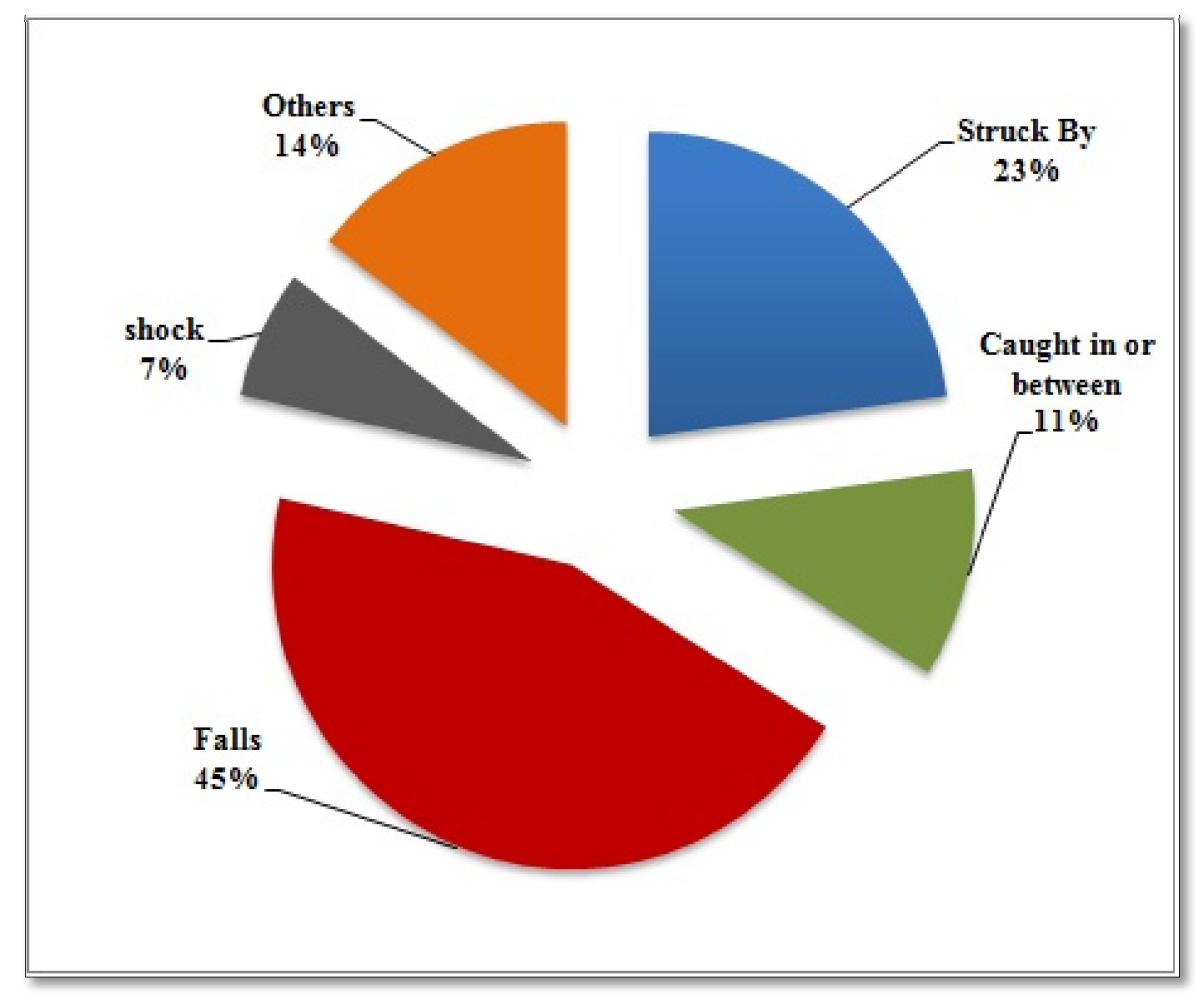

Figure 4-1: Percentage of occurrence of major types of accidents

Table 4-1 illustrates the comparison of findings of this study to Huang and Hinze (2003). The two changes noted here is that the share of fall accidents has increased by $24 \%$, while, shock related accidents were reduced by $48 \%$. 
Table 4-1: Comparison of percentage of occurrence of fatal four accidents

\begin{tabular}{|c|c|c|}
\hline Cause of Accident & $\begin{array}{c}\text { Huang and Hinze } \\
\mathbf{2 0 0 3}\end{array}$ & This Study \\
\hline Falls & $36.30 \%$ & $45 \%$ \\
\hline Struck By & $24.30 \%$ & $23 \%$ \\
\hline Caught in/ Between & $11.60 \%$ & $11 \%$ \\
\hline Shock & $13.40 \%$ & $7 \%$ \\
\hline Others & $14.50 \%$ & $14 \%$ \\
\hline
\end{tabular}

There is an overlap of data used, in this study and of Huang and Hinze's (2003) work. Table 4-2 presents the percentage of fall accidents tested for the latest dataset (Nov-2001 to May-2013), which is not previously tested. The percentage of fall accidents from Nov2001 to May-2013 was supposed to come more than 45\%, but it was found to be less than that. Since the IMIS database provided for this research study didn't contain any fall accident from 1990 to 1994, and this time period has been considered by Huang and Hinze (2003) in their analysis; therefore, it could be a possible reason for the error in this finding. In short, the finding clearly illustrates that fall accidents have considerably increased in the last decade, which means that the situation is getting worst in case of falls in the U.S. construction industry. 
Table 4-2: Percentage of fall accidents (Nov-2001 to May-2013)

\begin{tabular}{|c|c|c|c|}
\hline \multirow{4}{*}{$\begin{array}{c}\text { Cause of } \\
\text { Accident }\end{array}$} & $\begin{array}{c}\text { Huang and } \\
\text { Hinze } \\
\text { (2003) }\end{array}$ & $\begin{array}{c}\text { This } \\
\text { Research } \\
\text { Study }\end{array}$ & $\begin{array}{c}\text { This Research } \\
\text { (Balance after } \\
\text { Huang and } \\
\text { Hinze 2003) }\end{array}$ \\
\cline { 2 - 4 } & $\begin{array}{c}\text { Jan 1990-Oct } \\
\mathbf{2 0 0 1}\end{array}$ & $\begin{array}{c}\text { July 1994- } \\
\text { May 2013 }\end{array}$ & $\begin{array}{c}\text { Nov 2001-May } \\
\mathbf{2 0 1 3}\end{array}$ \\
\hline Falls & $36.34 \%$ & $45.00 \%$ & $44.33 \%$ \\
\hline
\end{tabular}

Fig 4-2 presents the trend of fall accidents in comparison to other types of accidents from 1996 to 2013. The data for years 1994 and 1995 has been excluded because the IMIS database only consisted of three reported cases out of which two were falls, and if included in the figure it would mislead the results presented by the trend line. It is evident from the analysis that falls had been nearly contributing to half of the accidents in the U.S. construction for the past two decades. Though, the trend line seems to have a slightly downward pattern, much work needs to done in order to curb the problem of falls. 


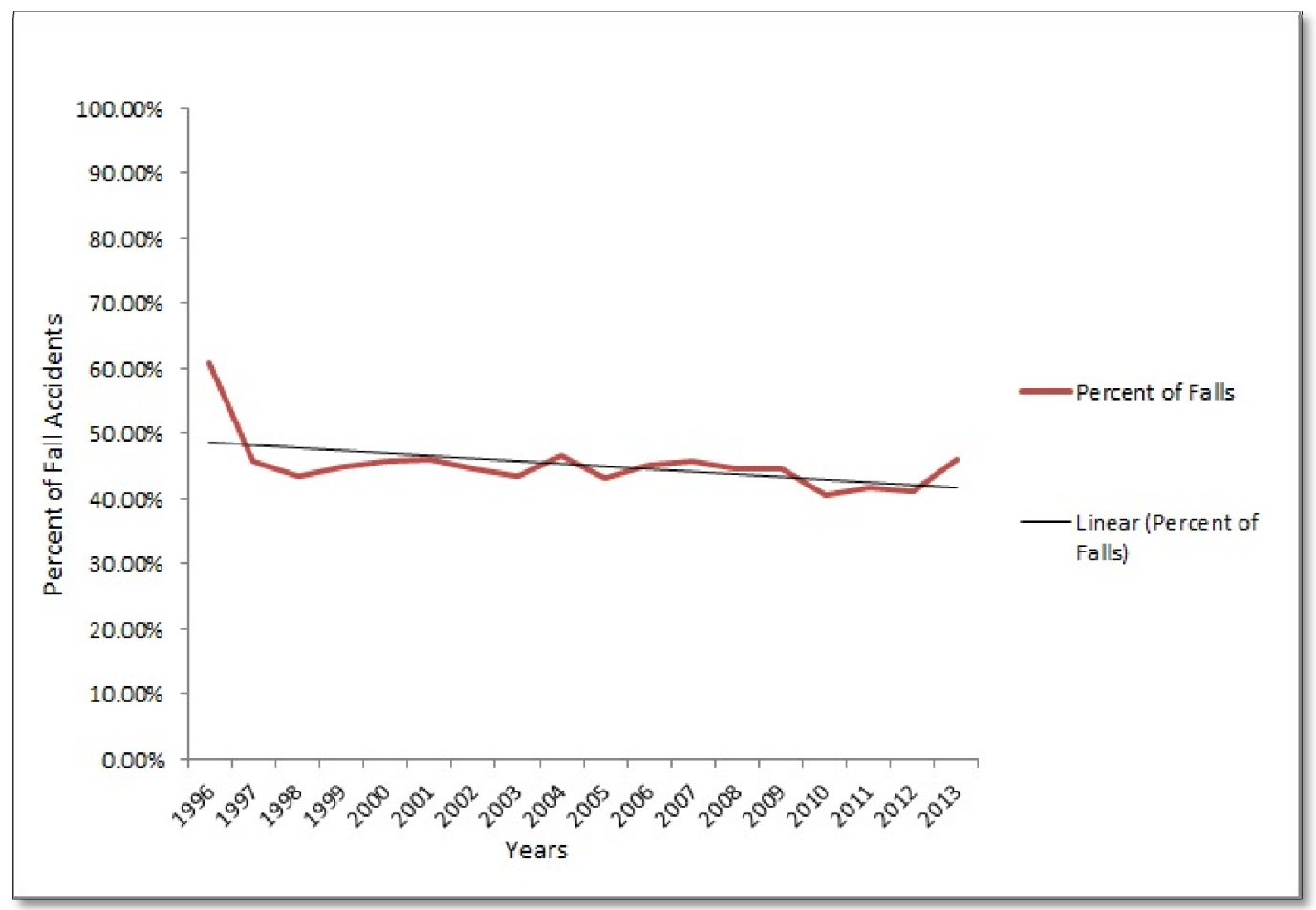

Figure 4-2: Trend of falls in the U.S. construction industry (1996-2013)

Accidents in the construction industry lead to different types of injuries such as serious or minor injuries, depending upon the severity of an accident. Fig 4-3 shows the distribution of fall accidents with respect to the class of injury (fatality/ hospitalization/ non-hospitalization) incurred to the victim. From the analysis of the OSHA's IMIS dataset it has been found that a little more than half of the victims of fall accidents suffered serious (hospitalized) injuries, whereas $37 \%$ of the victims lost their lives, and there is a very little percentage $(8 \%)$ of the victims who suffered a minor injury or in other words a non-hospitalized injury as a result of a fall accident. 


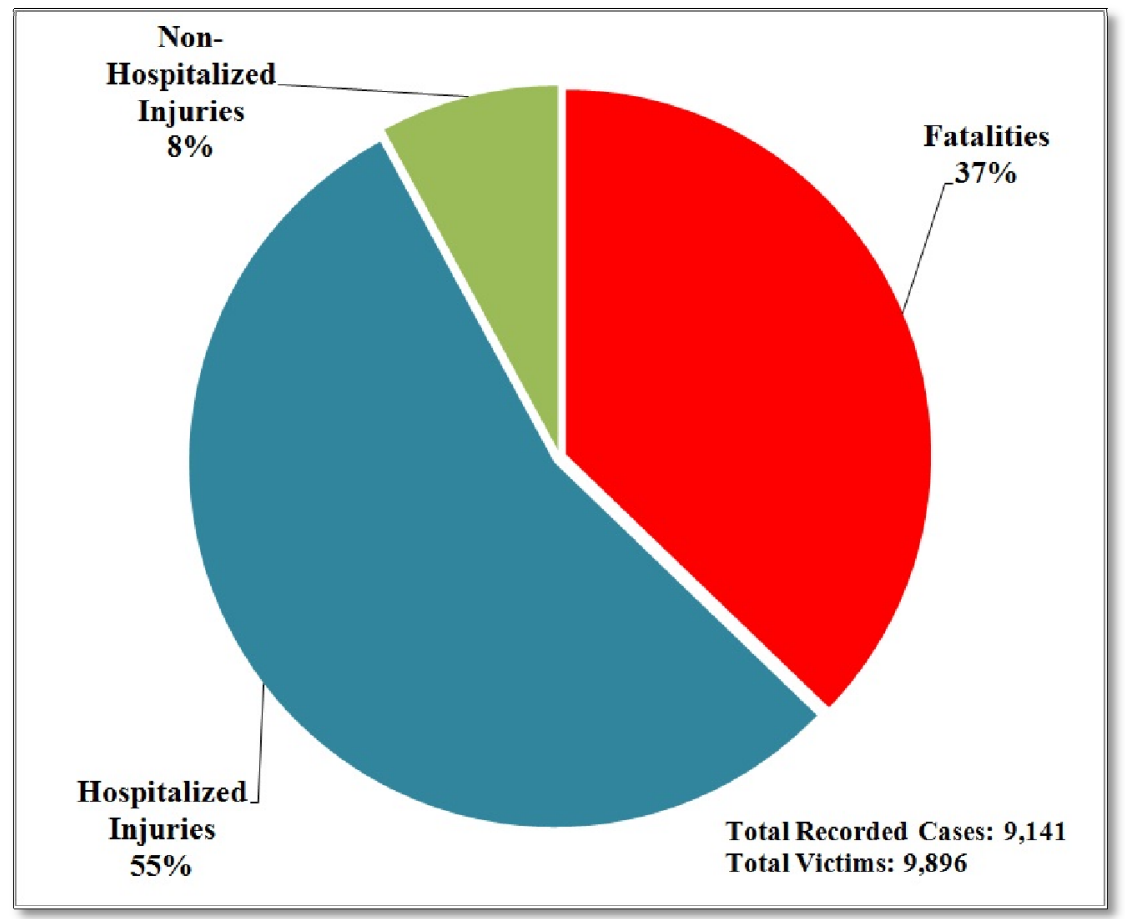

Figure 4-3: Fall accidents with respect to nature of injury

Figure 4-4 presents a comparison of severity of an accident in case of falls versus other fatal four accident categories. It has been found that fall accidents have the lowest percentage of fatal accidents as compared to the other three, but it has the highest incidence rate for serious (hospitalized) injuries. After shock related accidents, falls are found to be the most dangerous accidents, in terms of the severity of injury caused to the victims. Fall accidents usually lead to serious injuries, and that is why they are considered to be one of the most costly accidents (Gavious et al., 2009). 


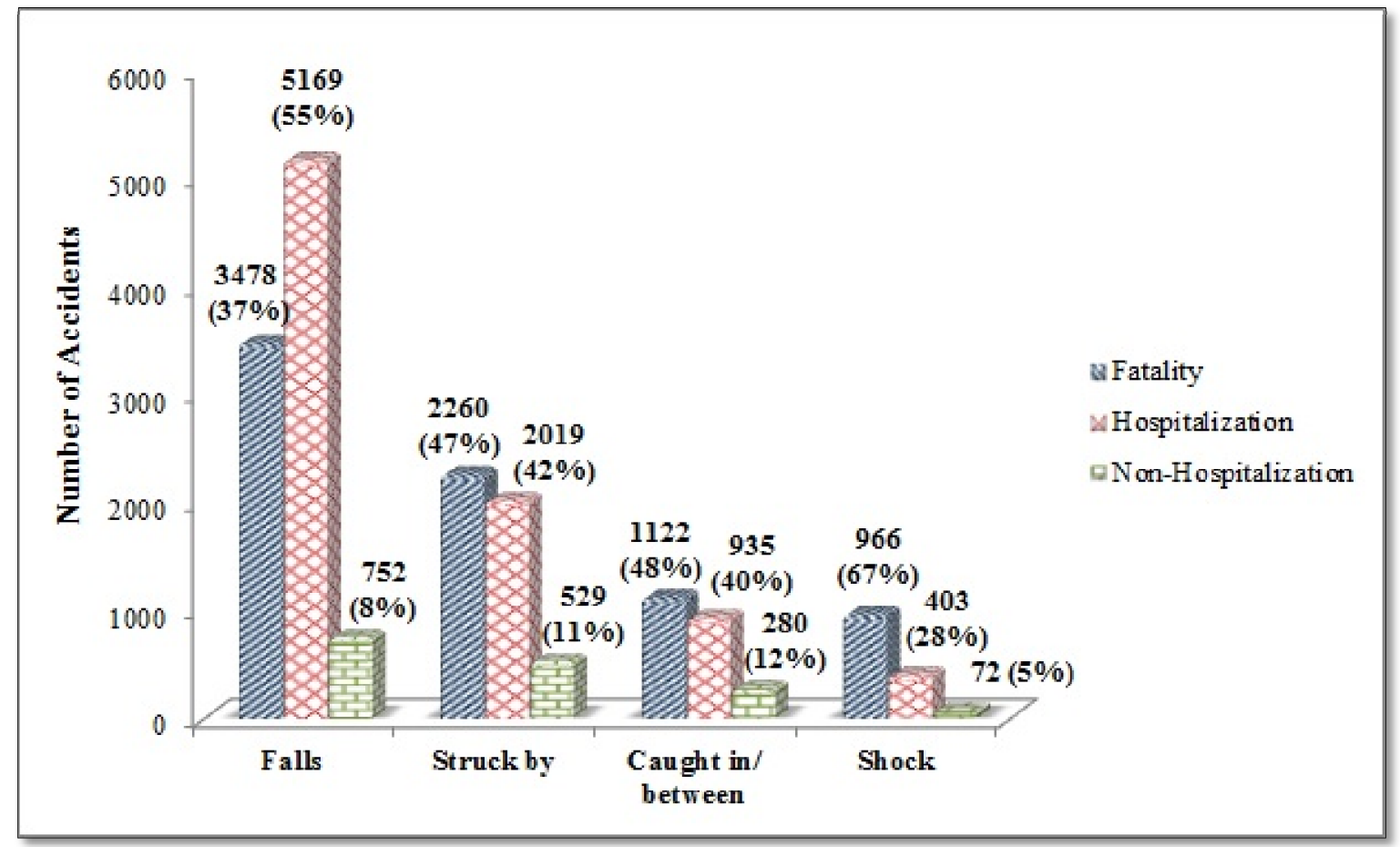

Figure 4-4: Comparison of severity of accident in OSHA's fatal four

\subsection{Analysis of Fall Accidents by Industry (SIC) Type and Project Characteristics}

\subsubsection{Industry Type}

Fig 4-5 shows the percentage of occurrence of fall accidents by industry type. It is found that that fall accidents have a very high incidence rate (6893 accidents, $75 \%)$ in SIC-17 (Specialty Trade Contractors) as compared to the other two categories SIC-15 (Building Construction) and SIC-16 (Heavy Construction). Greater concentrations of falls in specialty trade contractors' could be due to several reasons, which will be discussed in the discussion chapter. 


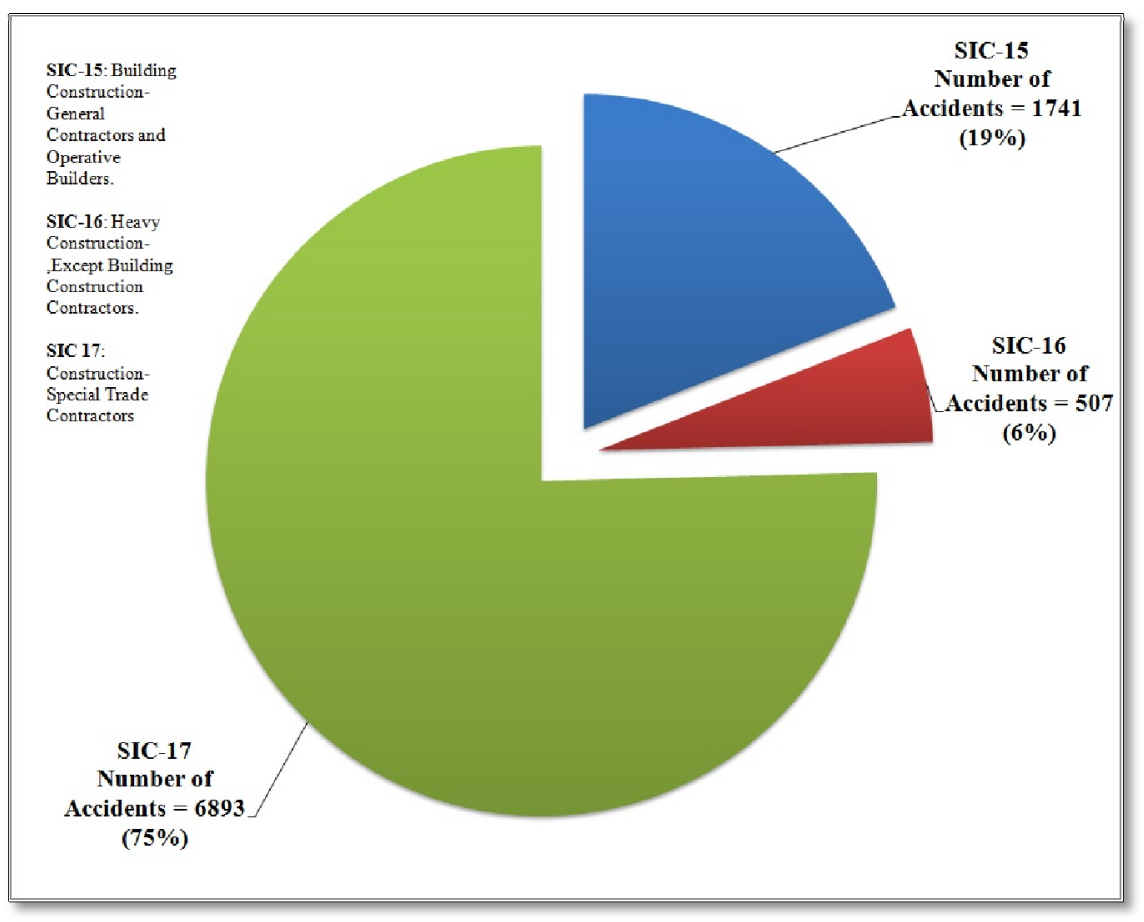

Figure 4-5: Fall accidents with respect to the SIC codes

Table 4-3 presents the comparison of findings of this study to previous research. Specialty trade contractors were found to be more susceptible to fall accidents and they continue to contribute to the majority of the falls. Specialty trade contractors also refer to those employers who are working on a smaller scale for a particular business/ trade e.g. roofing, siding and sheet metal works, carpentry work, etc. Due to limited resources, these small companies have a poor compliance to standards and regulations; therefore they encounter much more accidents as compared to the other trades (Hinze \& Gambatese, 2003). 
Table 4-3: Fall accidents by industry type

\begin{tabular}{|c|c|c|c|c|}
\hline Industry Type & $\begin{array}{c}\text { Saruda et al. } \\
\text { (1995) (only roof } \\
\text { fatalities } \\
\text { considered) }\end{array}$ & $\begin{array}{c}\text { Huang and } \\
\text { Hinze } \\
\text { (2003) }\end{array}$ & $\begin{array}{c}\text { Bobick } \\
\text { (2004) (only } \\
\text { fatalities } \\
\text { considered) }\end{array}$ & $\begin{array}{c}\text { This Research } \\
\text { Study }\end{array}$ \\
\hline $\begin{array}{c}\text { SIC-15 'General } \\
\text { Building } \\
\text { Construction' } \\
\text { involved in Falls }\end{array}$ & $24.50 \%$ & -- & $22.30 \%$ & $19.00 \%$ \\
\hline $\begin{array}{c}\text { SIC-16 'Heavy } \\
\text { Civil } \\
\text { Engineering } \\
\text { Works' involved } \\
\text { in Falls }\end{array}$ & $1.40 \%$ & -- & $7.50 \%$ & $6.00 \%$ \\
\hline $\begin{array}{c}\text { SIC-17 'Specialty } \\
\text { Trade } \\
\text { Contractors' } \\
\text { involved in Falls }\end{array}$ & $74.10 \%$ & $80 \%$ & $70.2 \%$ & $75 \%$ \\
\hline
\end{tabular}

\subsubsection{Construction End Use and Type of Construction}

Fig 4-6 shows a detailed distribution of falls in the U.S. construction industry with respect to various construction end uses. Out of 9,141 fall accidents, construction end use details were available for 9,093 accidents. The analysis for construction end use and type of construction are performed with respect to the number of accidents, since these are accident specific parameters independent to the victims. The descriptive analysis of fall accidents with respect to various construction end uses revealed that out of sixteen different categories there are two major project categories contributing to falls, i.e. commercial building and single family dwellings projects. They constitute for $50 \%$ of the fall accidents in the U.S. construction industry. These project categories need special 
attention from the regulators, as controlling fall accidents in these project categories will ultimately lower accidents in the industry as a whole.

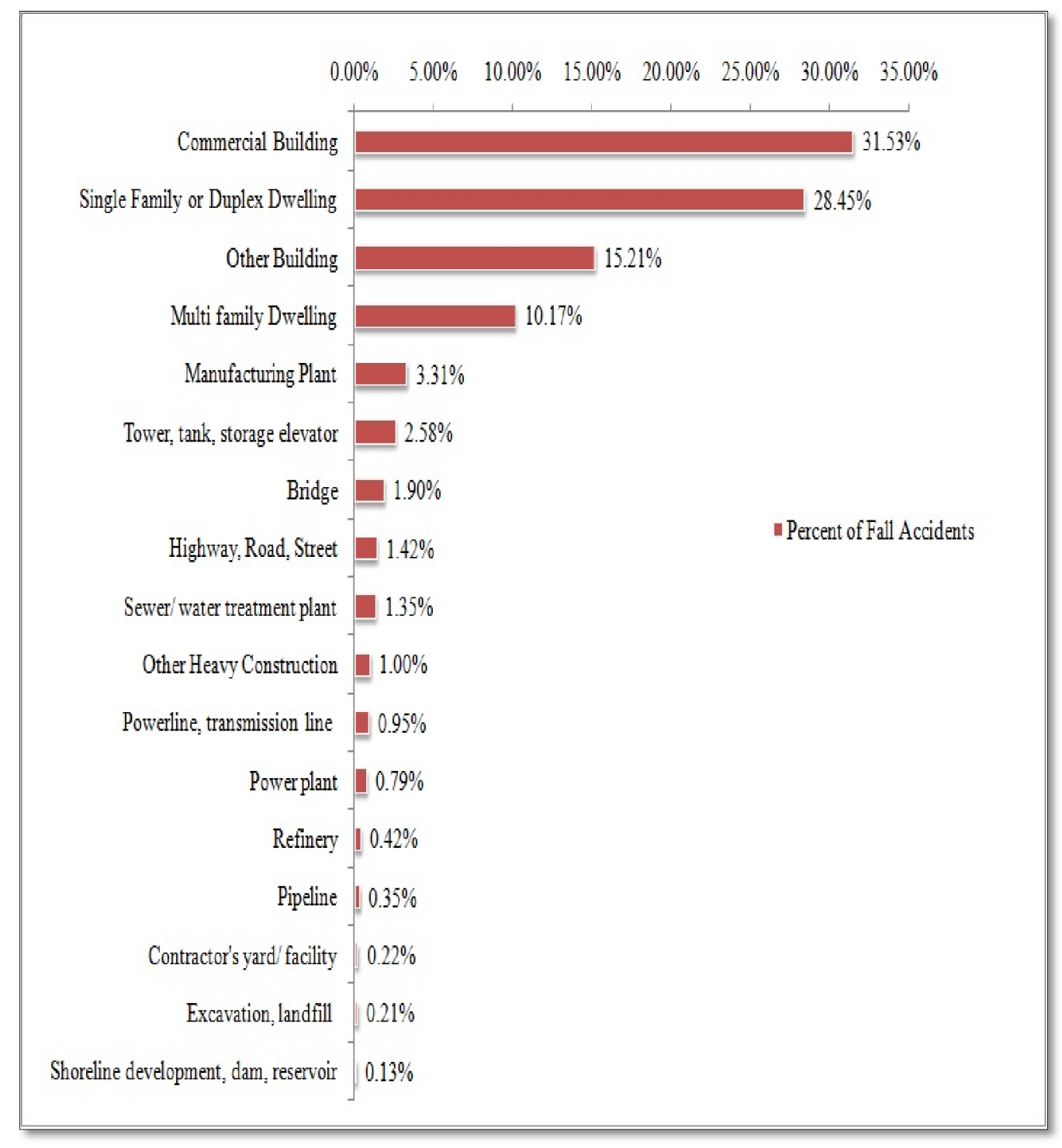

Figure 4-6: Fall accidents with respect to construction end use

Table 4-4 presents a comparison of findings of this research to Huang and Hinze (2003). It was noted that the situation is unchanged for most of the project types, but in case of falls on the single family dwelling projects, there has been a significant increase 
noted in the number of accidents; which means that for such projects, situation is getting worst in terms of safety and fall protection. It could be due to the fact that residential construction sector experienced a significant rise (The Construction Chart Book, 2013) in the past decade, which led to greater accidents. Further discussion regarding this will be provided in the discussion chapter. The reason for commercial building projects with highest falls could be attributed to the nature of work involved on such projects.

Table 4-4: Comparison of fall accidents by different construction end uses

\begin{tabular}{|c|c|c|}
\hline Construction End Use & $\begin{array}{c}\text { Huang and } \\
\text { Hinze } \\
\text { (2003) }\end{array}$ & $\begin{array}{c}\text { This Research } \\
\text { Study }\end{array}$ \\
\hline Commercial Building & $33.30 \%$ & $31.53 \%$ \\
\hline Single Family or Duplex Dwelling & $17.40 \%$ & $28.44 \%$ \\
\hline Other Building & $17.40 \%$ & $15.21 \%$ \\
\hline Multi family Dwelling & $9.30 \%$ & $10.17 \%$ \\
\hline Others & $22.1 \%$ & $14.63 \%$ \\
\hline
\end{tabular}

The details of nature of construction work were available for 9,093 cases out of 9,141 accidents. It is found that new projects or new additions have majority of the fall accidents in the U.S. construction industry (Fig 4-7). 


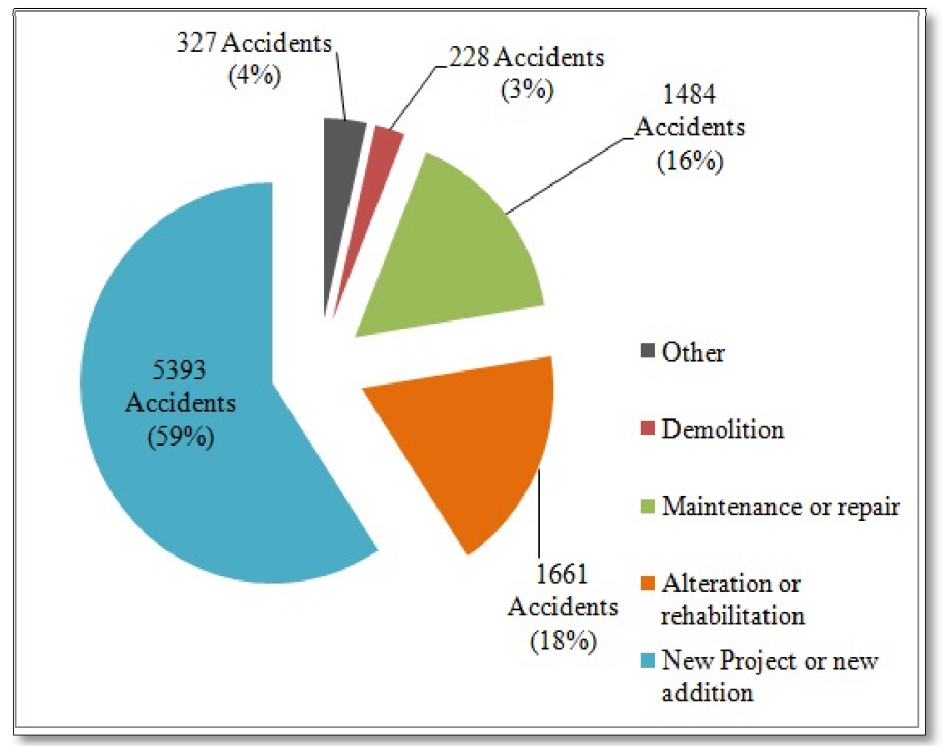

Figure 4-7: Falls with respect to the type of construction

Table 4-5 presents a comparison of findings of this study to Huang and Hinze (2003). The comparison suggests that there is no significant change noted in this particular measure, in the past decade. Construction work on new projects or new additions continues to be more vulnerable to falls.

Table 4-5: Comparison of falls with respect to nature of construction

\begin{tabular}{|c|c|c|}
\hline Type of Construction & $\begin{array}{c}\text { Huang and } \\
\text { Hinze } \\
\text { (2003) }\end{array}$ & $\begin{array}{c}\text { This Research } \\
\text { Study }\end{array}$ \\
\hline $\begin{array}{c}\text { New Project or new } \\
\text { addition }\end{array}$ & $59.30 \%$ & $59.32 \%$ \\
\hline $\begin{array}{c}\text { Alteration or } \\
\text { rehabilitation }\end{array}$ & $18.00 \%$ & $18.26 \%$ \\
\hline Maintenance or repair & $15.60 \%$ & $16.32 \%$ \\
\hline Other & $3.40 \%$ & $3.60 \%$ \\
\hline Demolition & $3.40 \%$ & $2.51 \%$ \\
\hline
\end{tabular}




\subsubsection{Size of Project}

The size of the project is a descriptive parameter, and it is measured with respect to the cost of the project or project budget. The details of the project budget were available for 9,092 cases out of 9,141 fall accidents. The analysis for cost of the project is performed with respect to the number of accidents, since this parameter is accident specific independent to the victims. Fig 4-8 shows the distribution of fall accidents with respect to various cost ranges. The descriptive analysis of the OSHA's IMIS dataset revealed that fall accidents occur more frequently on projects with lesser budgets as compared to big and high budget projects. This means that there are more fall accidents on smaller projects rather than the big ones. It is also noted that more than half of the falls occur on considerably low budget $(\leq \$ 250,000)$ projects. This could be due to the fact that the majority of the low budget projects are executed by small specialty trade contractors, and they are more vulnerable to falls due lack of education and safety culture.

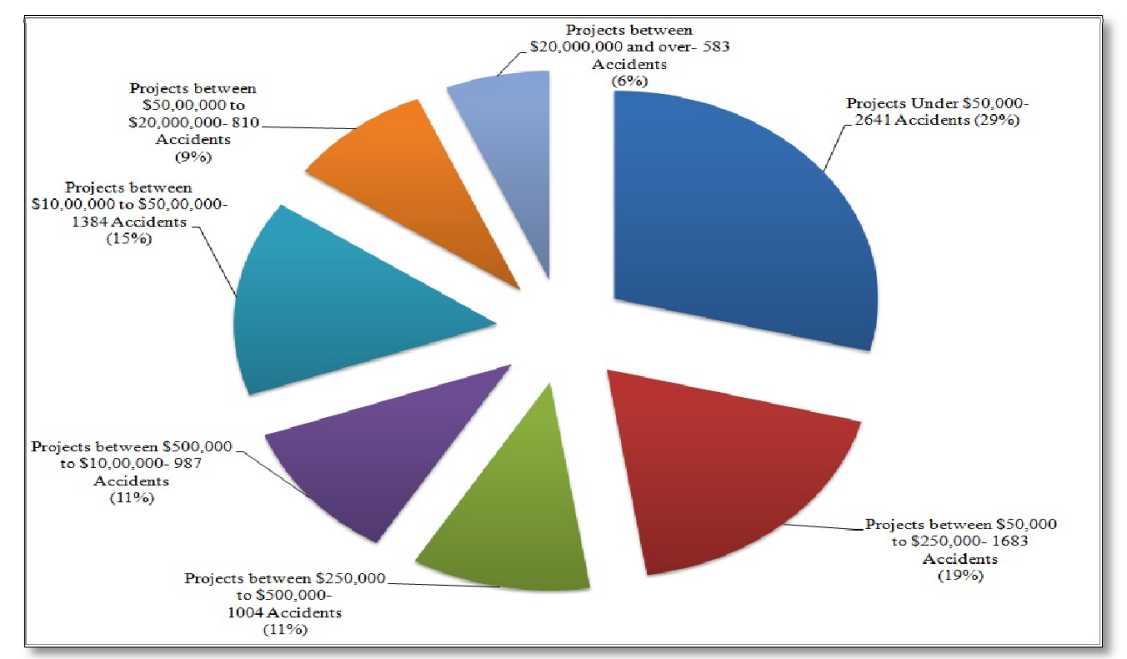

Figure 4-8: Fall accidents with respect to cost of the project 
Table 4-6 presents a comparison of findings of this study with Huang and Hinze (2003). It has been found that there is no significant change noted in the number of falls with respect to the project budget. Low-cost projects continue to contribute to the majority of falls in the U.S. construction industry.

Table 4-6: Comparison of fall accidents with respect to cost of project

\begin{tabular}{|c|c|c|}
\hline Project Budget & $\begin{array}{c}\text { Huang and } \\
\text { Hinze } \\
\text { (2003) }\end{array}$ & $\begin{array}{l}\text { This Research } \\
\text { Study }\end{array}$ \\
\hline $\begin{array}{l}\text { Projects between Under } \\
\$ 50,000\end{array}$ & $28.10 \%$ & $29 \%$ \\
\hline $\begin{array}{c}\text { Projects between } \\
\$ 50, \text { OOO to } \$ 250, \text { OOO }\end{array}$ & $18.80 \%$ & $19 \%$ \\
\hline $\begin{array}{c}\text { Projects between } \\
\$ 250, \text { OOO to } \$ 500,000\end{array}$ & $9.80 \%$ & $11 \%$ \\
\hline $\begin{array}{c}\text { Projects between } \\
\$ 500,000 \text { to } \$ 10,00,000\end{array}$ & $11 \%$ & $11 \%$ \\
\hline $\begin{array}{c}\text { Projects between } \\
\$ 10,00,000 \text { to } \\
\$ 50,00,000\end{array}$ & $15.50 \%$ & $15 \%$ \\
\hline $\begin{array}{c}\text { Projects between } \\
\$ 50,00, \text { oOO to } \\
\$ 20,000,000\end{array}$ & $9.60 \%$ & $9 \%$ \\
\hline $\begin{array}{c}\text { Projects between } \\
\$ 20, \text { OOO,OOO and over }\end{array}$ & $6.80 \%$ & $6 \%$ \\
\hline
\end{tabular}




\subsection{Analysis of fall accidents by trades, Fall Type, Fall Height, Fall Protection, and Nature of Injuries}

\subsubsection{Trades}

Fig 4-9 illustrates the distribution of fall accidents with respect to different trades amongst the three standard industrial classification codes (SIC) of the construction industry. The analysis for this parameter is performed with respect to the number of accidents, since it is an accident specific parameter independent to the victims. The figure shows that out of twenty-six different trades in the U.S. construction industry, the trade of roofing, siding and sheet metal work experienced the highest number of fall accidents. It can be attributed to the nature of work involved for this particular profession making it riskier in regards to fall hazards and safety in general. Moreover, a very important finding to be noted here is that, the following prominent trades are responsible for nearly half of the falls: roofing, siding and sheet metal works, carpentry works, structural steel erection works and single family housing construction. The findings presented above calls for increased awareness, education and training about fall hazards in particular to specialty trade contractors and other stakeholders who are involved in such risky professions. Moreover, there is a requirement of more frequent inspections by OSHA, so that there would be greater compliance to the regulations. 


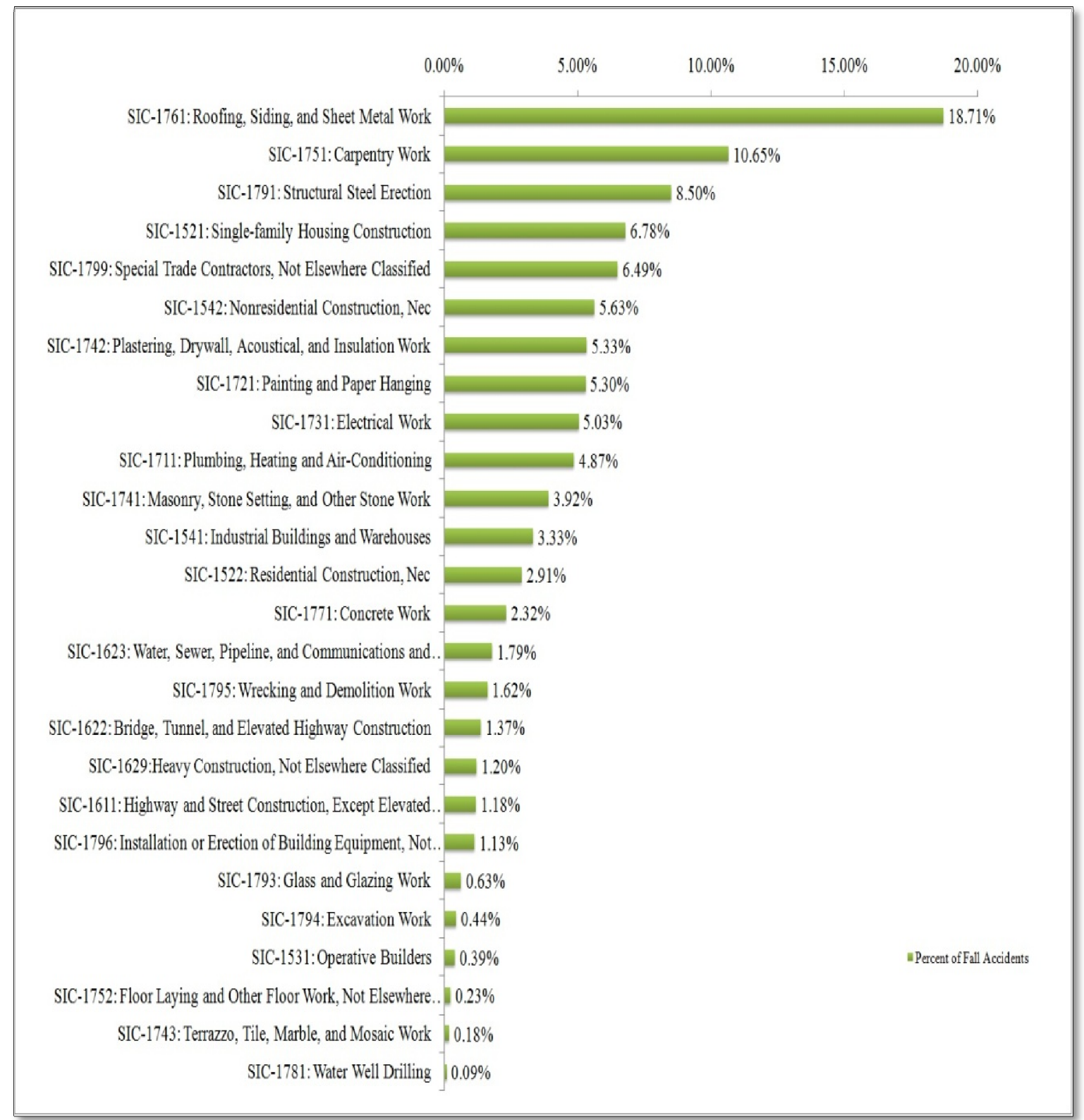

Figure 4-9: Fall Accidents with respect to different trades/ professions (SIC Codes)

The results obtained from the analysis of falls with respect to various trade/ professional categories, were in line with the previous studies, Bobick (2004), Huang and Hinze (2003), Janicak (1998), Suruda et al. (1995). It shows that there is no improvement whatsoever in these high risk professions. Table 4-7 shows a comparison of occurrence of falls for these high risk professions, which is done by comparing the analyzed results of 
this study to similar previous studies, Bobick (2004) and Huang and Hinze (2003). It was noted that there is no significant change in the number of fall accidents in case of roofing, siding and sheet metal work trade, whereas for carpentry works, there is an increase in the number of fall accidents and for structural steel erections works there is a slight decrease noted in the number of falls. The rise in number of fall accidents in carpentry trade may possibly be related to the economic boom of the residential construction sector in the last decade (The Construction Chart Book, 2013). Further discussion regarding this is made in the discussion chapter.

Table 4-7: Percentage of fall accidents in major fall prone trade categories

\begin{tabular}{|c|c|c|c|}
\hline $\begin{array}{c}\text { Trade } \\
\text { Category }\end{array}$ & $\begin{array}{c}\text { Huang and } \\
\text { Hinze (2003) }\end{array}$ & $\begin{array}{c}\text { Bobick } \\
\text { (2004) (only } \\
\text { fatalities } \\
\text { considered) }\end{array}$ & $\begin{array}{c}\text { This } \\
\text { Research } \\
\text { Study }\end{array}$ \\
\hline $\begin{array}{c}\text { SIC-1761: } \\
\text { Roofing, } \\
\text { Siding, and } \\
\text { Sheet Metal } \\
\text { Work }\end{array}$ & $16.85 \%$ & $18.77 \%$ & $18.71 \%$ \\
\hline $\begin{array}{c}\text { SIC-1751: } \\
\text { Carpentry } \\
\text { Work }\end{array}$ & $6.50 \%$ & $6.18 \%$ & $10.65 \%$ \\
\hline $\begin{array}{c}\text { SIC-1791: } \\
\text { Structural }\end{array}$ & $13.37 \%$ & $10.52 \%$ & $8.50 \%$ \\
\hline
\end{tabular}

\subsubsection{Fall Type/ Cause}

There are several physical causal factors that can lead to a fall accident. The accident investigation summaries from the OSHA's IMIS database were reviewed in detail for this 
research study and then subsequently coded with different fall causal codes (e.g. falls from the roof, ladders, etc.). The analysis for this parameter is performed with respect to the number of victims, as it is a victim specific parameter and an accident may involve more than one victim experiencing different fall causal factors. Fig 4-10 shows the percentage of occurrence of various fall causal factors. It is clearly elucidated from the analysis that falls from roofs, ladders and scaffolds contribute to nearly $55 \%$ of the falls.

Falls from the roofs alone contribute to approximately $25 \%$ of the falls, which shows the severity of the problem of fall accidents associated with the roofing works and workers engaged in activities associated with the roofing works.

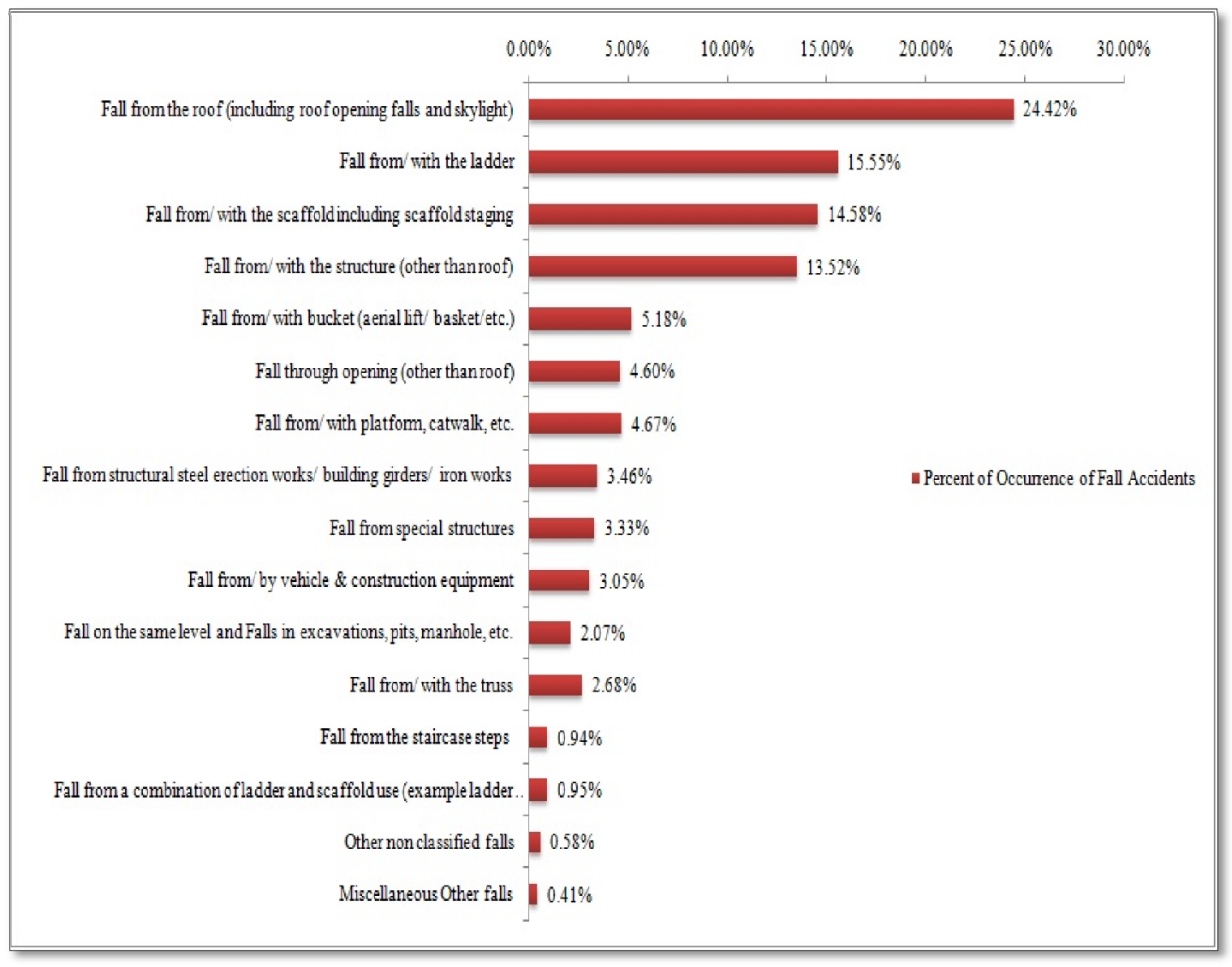

Fig 4-10: Percentage of occurrence of various fall causal codes/ factors 
Table 4-8 presents a comparison of findings of this research study to Huang and Hinze (2003). The top four causal categories i.e. falls from the roof, ladder, scaffold and structure remains to be unchanged in the past two decades, but there is an increase noted in the number of falls from the ladders. This increase may be due the increased construction activity in the residential construction sector in the past decade (The Construction Chart Book, 2013), which might led to the increased use of ladders that subsequently increased ladder falls. Further discussion regarding this is made in the discussion chapter. Moreover, the analysis of U.S. BLS (2003-2010) fatalities data also revealed that fatal falls, from the ladders have increased in the past decade.

Table 4-8: Comparison of percentage of major causes of fall accidents

\begin{tabular}{|c|c|c|}
\hline Major Causes of Falls & $\begin{array}{c}\text { Huang and } \\
\text { Hinze (2003) }\end{array}$ & $\begin{array}{c}\text { This Research } \\
\text { Study }\end{array}$ \\
\hline Falls from the roof & $28.36 \%$ & $24.42 \%$ \\
\hline Falls from/with ladder & $11.33 \%$ & $15.55 \%$ \\
\hline $\begin{array}{c}\text { Falls from/with scaffold } \\
\text { staging }\end{array}$ & $13.03 \%$ & $14.58 \%$ \\
\hline $\begin{array}{c}\text { Falls from/with } \\
\text { structure }\end{array}$ & $19.34 \%$ & $13.52 \%$ \\
\hline Falls through opening & $7.67 \%$ & $5.18 \%$ \\
\hline $\begin{array}{c}\text { Falls from/ with bucket } \\
\text { (aerial lift/ basket) }\end{array}$ & $3.15 \%$ & $4.60 \%$ \\
\hline $\begin{array}{c}\text { Falls from/ with } \\
\text { platform catwalk }\end{array}$ & $2.39 \%$ & $4.67 \%$ \\
\hline $\begin{array}{c}\text { Fall from vehicle } \\
\text { (vehicle/ construction } \\
\text { equipment) }\end{array}$ & $2.30 \%$ & $3.05 \%$ \\
\hline
\end{tabular}




\subsubsection{Height of fall}

The height of fall is a very important parameter for a study discussing fall accidents. The information about the fall height of the victims was available for about $72 \%(6,525$ cases out of 9,141 ) of the cases in the provided dataset. The analysis for this parameter is performed with respect to the number of victims, since it is a victim specific parameter; there can be multiple workers involved in an accident, which may have different falling heights. Fig $4-11$ shows that approximately $85 \%$ of the falls occur on heights $\leq 30 \mathrm{ft}$. One more interesting finding to be noted here is that $43 \%$ of the falls occur between $10-20 \mathrm{ft}$., working heights. These heights do not sound much risky, but the main point of concern here is that the majority of falls occur on considerably lower heights.

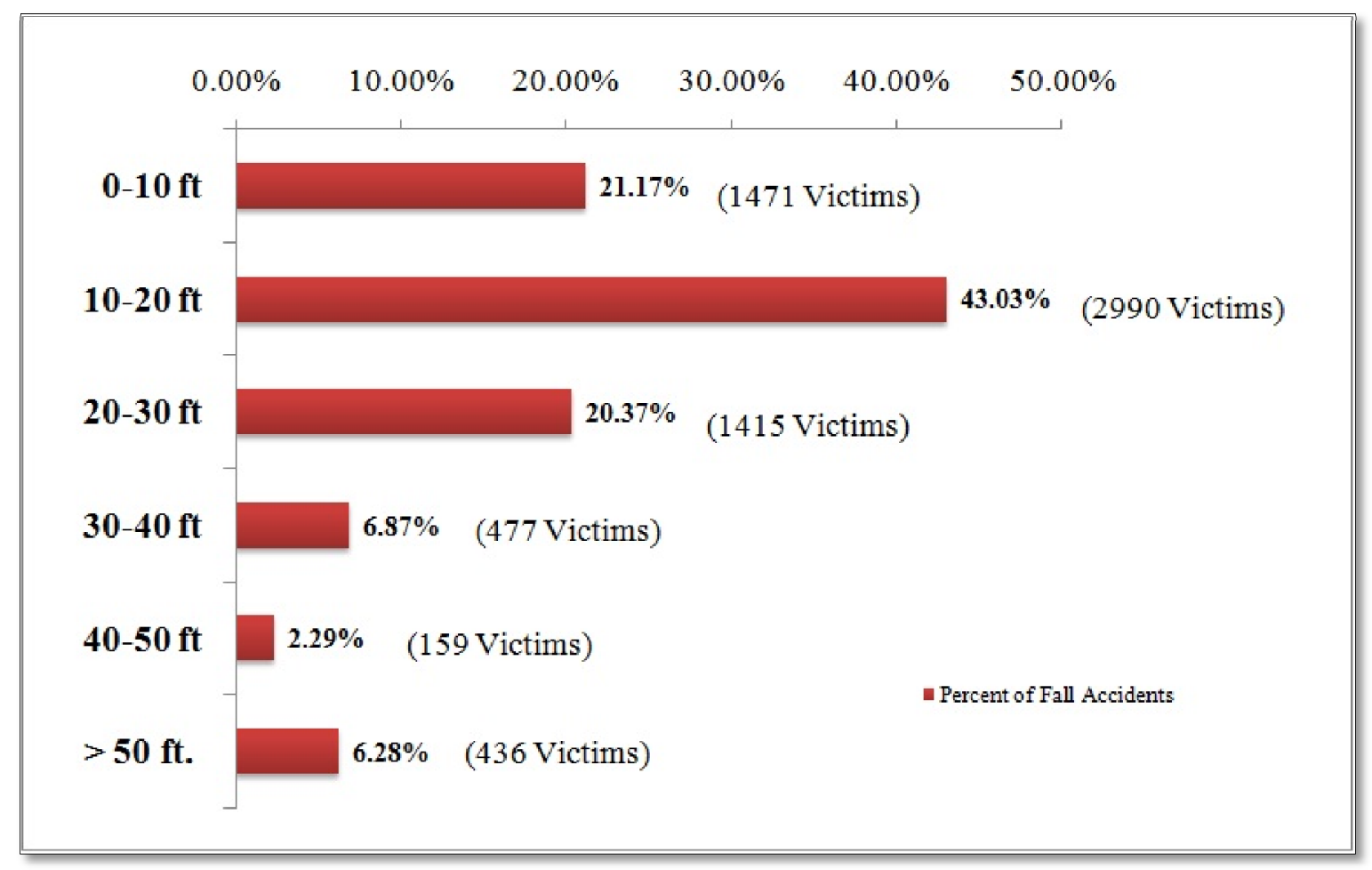

Figure 4-11: Fall accidents by working height (ft.) 
Fig 4-12 shows the average height of fall with respect to various types of construction end uses. It is very interesting to note that the average height of fall for projects (single family dwellings, commercial buildings and multifamily dwellings) which constitute nearly $70 \%$ of the falls in U.S. construction industry is well under $25 \mathrm{ft}$. The combined data of falling height and construction end use was available for 6,493 accidents out of the total of 9,141 accidents.

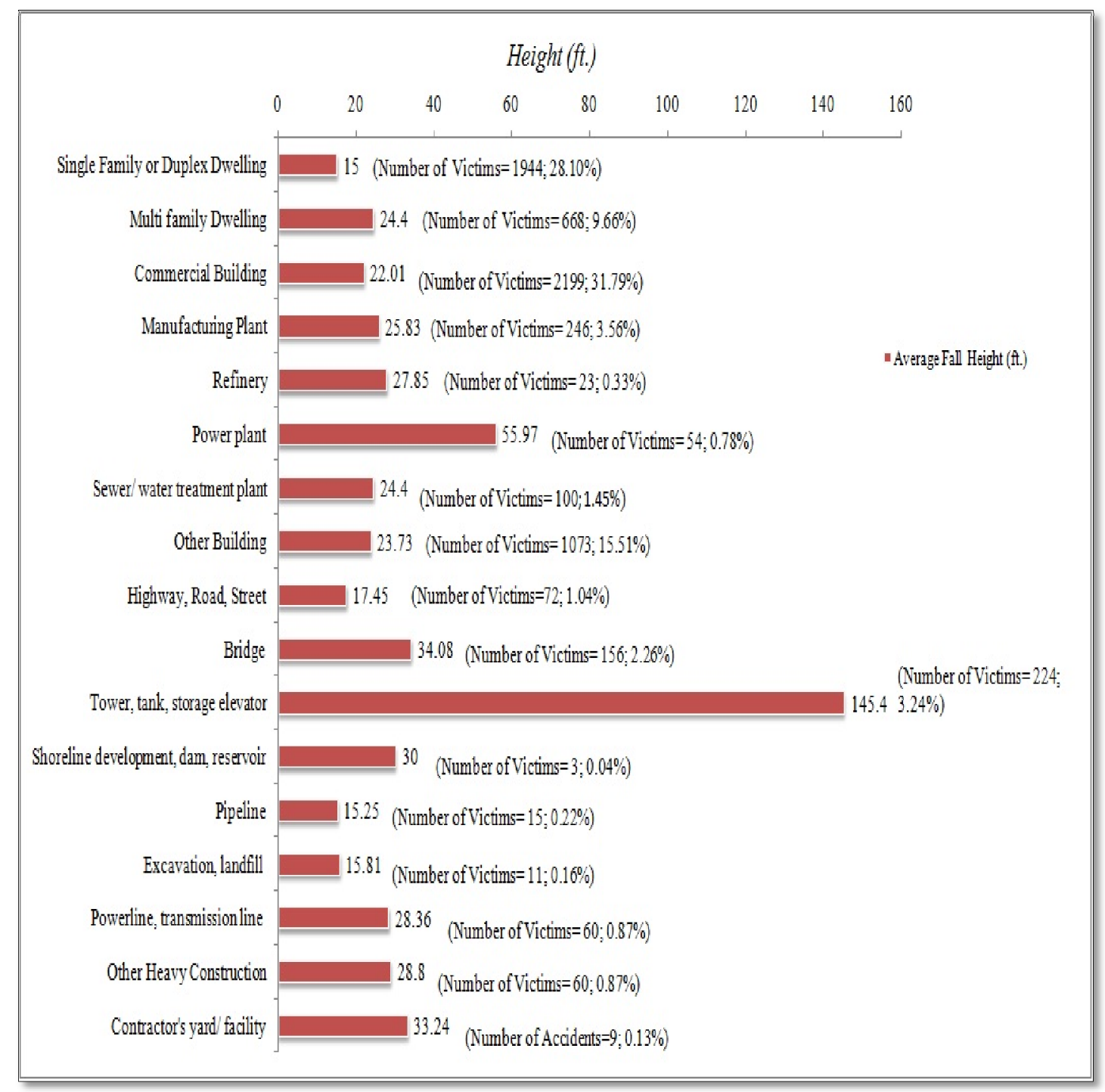

Figure 4-12: Average height of fall (ft.) for various types of construction end uses 
Table 4-9 presents a comparison of falling heights with Huang and Hinze (2003). The only significant change noted is the increase in the percentage of falls between 10-20 ft. working heights, whereas the other percentages tend to be more or less the same with no change in the number of falls on heights $\leq 30 \mathrm{ft}$. The increase in falls on heights between $10 \mathrm{ft}$. to $20 \mathrm{ft}$. could be due to rise in the residential construction sector of the U.S. in the early 2000's (The Construction Chart Book, 2013), as work on such heights is generally performed on residential construction projects.

Table 4-9: Comparison of fall accidents with respect to different height (ft.) Intervals

\begin{tabular}{|c|c|c|}
\hline $\begin{array}{c}\text { Height of } \\
\text { Fall (ft.) }\end{array}$ & $\begin{array}{c}\text { Huang and } \\
\text { Hinze } \\
\text { (2003) }\end{array}$ & $\begin{array}{c}\text { This Research } \\
\text { Study }\end{array}$ \\
\hline $0-10 f t$. & $23 \%$ & $21.17 \%$ \\
\hline $10-20 f t$. & $28 \%$ & $43.03 \%$ \\
\hline $20-30 f t$. & $22 \%$ & $20.37 \%$ \\
\hline $30-40 f t$. & $8 \%$ & $6.87 \%$ \\
\hline
\end{tabular}

These discussed analysis are performed using a combination of descriptive and combined analysis, in order to analyze the parameter of height of fall. It is pretty safe to state that the majority of the fall accidents occur on residential housing and commercial building projects at heights less than $30 \mathrm{ft}$. Most of these accidents could have been avoided if proper safety measures had been adopted by the workers (Huang \& Hinze, 2003). 


\subsubsection{Fall Protection}

The accident investigation summaries in the OSHA's IMIS dataset were thoroughly studied, and subsequently the cases were coded about the presence, absence, and/ or misuse of the fall protection. Not all the cases summaries contained such detailed information as some had no details whatsoever about fall protection and safety. Therefore, a total of 3,102 (34\%) cases from the data set of 9,141 cases were identified which had such information available in their investigation summaries. The analysis for fall protection parameter is performed with respect to the victims, since it is a victim specific parameter. An accident may involve multiple victims, which might or might not be using fall protection. Descriptive and combined analyses were performed to report different characteristics and influential factors associated with the use of fall protection.

Fig 4-13 presents the findings obtained as a result of descriptive analysis of fall protection parameter. High-level of noncompliance to fall standards and regulations is noted. It has been noted, that at $73 \%$ of the instances fall protection was missing. 


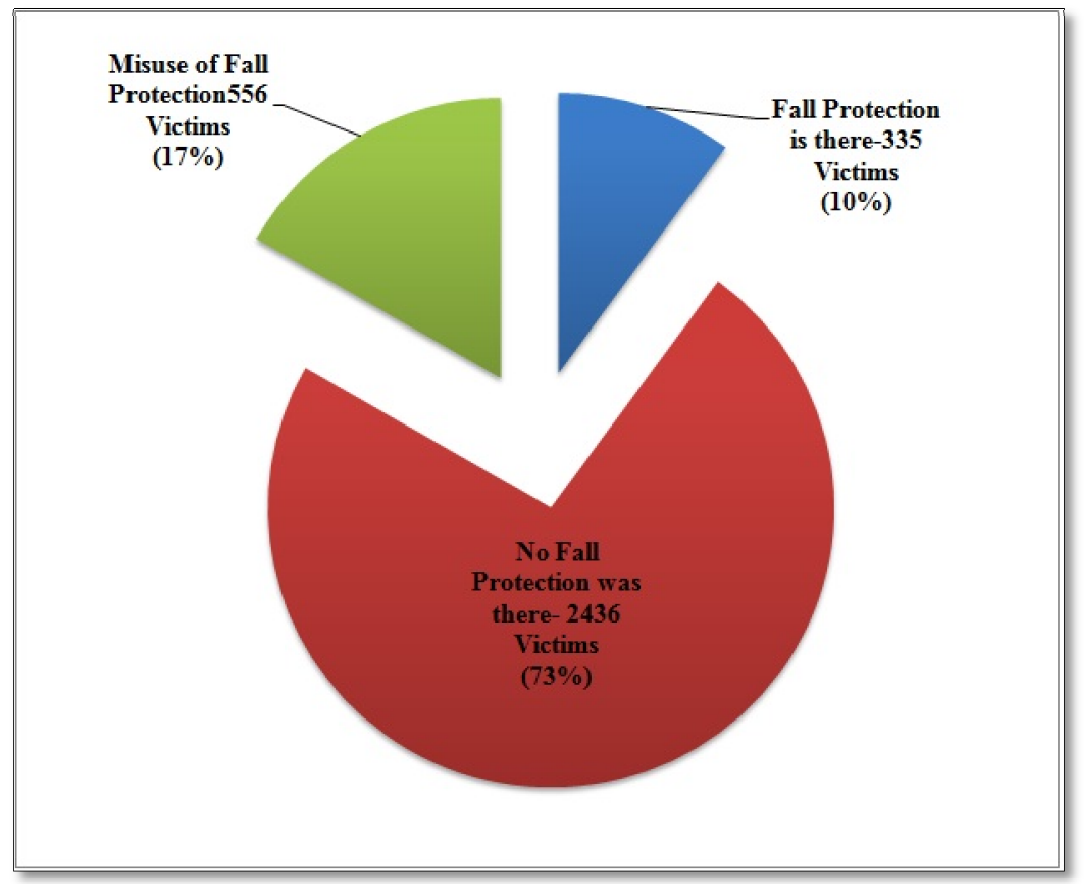

Figure 4-13: Fall protection usage in the U.S. construction industry

In the previous research studies, fall protection parameter has not been addressed specifically using IMIS database. Table 4-10 shows the comparison of findings of this study with the available details from the previous studies in regards to the usage of fall protection. Since the information about fall protection is not explicitly defined by previous studies, the results cannot be compared in detail. The results of this research, may possibly present a more representative outcome as they are based on the analysis of last twenty year dataset, unlike previous researches, who catered comparatively smaller datasets or researched for only specific types of accidents, such as fatal accidents. 
Table 4-10: Comparison of usage of fall protection from previous studies

\begin{tabular}{|c|c|c|c|}
\hline $\begin{array}{c}\text { Fall } \\
\text { Protection }\end{array}$ & $\begin{array}{c}\text { Janicak } \\
\text { (1998) (only } \\
\text { fatalities } \\
\text { considered) }\end{array}$ & $\begin{array}{c}\text { Huang and } \\
\text { Hinze } \\
\text { (2003) }\end{array}$ & $\begin{array}{c}\text { This Research } \\
\text { Study }\end{array}$ \\
\hline $\begin{array}{c}\text { Fall } \\
\text { Protection is } \\
\text { Present }\end{array}$ & -- & -- & $10 \%$ \\
\hline $\begin{array}{c}\text { Fall } \\
\text { Protection is } \\
\text { Absent }\end{array}$ & $35.30 \%$ & -- & $73 \%$ \\
\hline $\begin{array}{c}\text { Misuse of } \\
\text { Fall } \\
\text { Protection }\end{array}$ & $12 \%$ & $30 \%$ & $17 \%$ \\
\hline
\end{tabular}

Combined analysis was performed to analyze the falling heights (ft.) on which fall protection is being used, not used or misused. This analysis is performed with respect to the number of victims, as there could be more than one person involved in an accident. The combined data for fall protection and fall height were available for 2,631 victims. Table 4-11 illustrates, that the trend of usage of fall protection is increased with the increase of working height. There is a high percentage of lack of usage of protection at heights $\leq 30 \mathrm{ft}$., and accidents on such heights contribute to nearly $80 \%$ of the falls. The results suggest that the usage of fall protection is triggered by working heights. Further discussion will be provided in the discussion chapter. 
Table 4-11: Trend of usage of fall protection at different height intervals

\begin{tabular}{|c|c|c|c|c|c|}
\hline Height Range (ft.) & Fall Protection is Present & Foll Protection is Absent & Fall Protection is Misused & Total Victims & Percent \\
\hline $0-10 \mathrm{ft}$ & $11.61 \%$ & $79.16 \%$ & $9.23 \%$ & 379 & $14.41 \%$ \\
\hline $10-20 \mathrm{ft}$ & $6.90 \%$ & $79.93 \%$ & $13.17 \%$ & 1116 & $42.42 \%$ \\
\hline $20-30 \mathrm{ft}$ & $7.20 \%$ & $75.13 \%$ & $17.67 \%$ & 583 & $22.16 \%$ \\
\hline $30-40 \mathrm{ft}$ & $12.70 \%$ & $66.39 \%$ & $20.90 \%$ & 244 & $9.27 \%$ \\
\hline $40-50 \mathrm{ft}$ & $15.07 \%$ & $57.53 \%$ & $27.40 \%$ & 73 & $2.77 \%$ \\
\hline $50-60 \mathrm{ft}$ & $21.43 \%$ & $57.14 \%$ & $21.43 \%$ & 42 & $1.60 \%$ \\
\hline $60-80 \mathrm{ft}$ & $30.77 \%$ & $44.62 \%$ & $24.62 \%$ & 65 & $2.47 \%$ \\
\hline $80-100 \mathrm{ft}$ & $34.48 \%$ & $31.03 \%$ & $34.48 \%$ & 29 & $1.10 \%$ \\
\hline $100-150 \mathrm{ft}$ & $21.74 \%$ & $19.57 \%$ & $58.70 \%$ & 46 & $1.75 \%$ \\
\hline $150-200 \mathrm{At}$ & $21.05 \%$ & $15.79 \%$ & $63.16 \%$ & 19 & $0.72 \%$ \\
\hline$>200 \mathrm{ft}$ & $20.00 \%$ & $25.71 \%$ & $54.29 \%$ & 35 & $1.33 \%$ \\
\hline \multicolumn{4}{|c|}{ Total Victims } & 2631 & \\
\hline
\end{tabular}

Another examination was conducted by performing combined analysis on the dataset in order to observe the class of injury with respect to the practice of having or not having fall protection. Fig 4-14 illustrates the effectiveness of usage of fall protection. There were only 335 victims $(10.07 \%)$ when the fall protection was used. Whereas, on the other hand, there were 2,435 victims $(73.2 \%)$ when the fall protection was not there, and there were 556 victims $(16.7 \%)$ when the fall protection was misused. It was noted that $35 \%$ of the victims got fatally injured when the fall protection was present, whereas $39 \%$ got fatally injured when the fall protection was missing. These two percentages may not be comparable, since there is a huge difference in the number of victims. The findings clearly show the disadvantages of not using fall protection as the results would lead to social and economic problems for the victims and their families. Moreover, it causes 
severe financial trouble for the employers too. This calls for increased awareness and training for workers. Employers should make sure that their each and every employee is well trained and provided with the suitable PPE, to encounter such situations. Employers should principally act on the following, OSHA's fall protection guidelines: "Plan" the job ahead, "Provide" the right equipment to the workers to get the job done, and "Train" them how to use it.

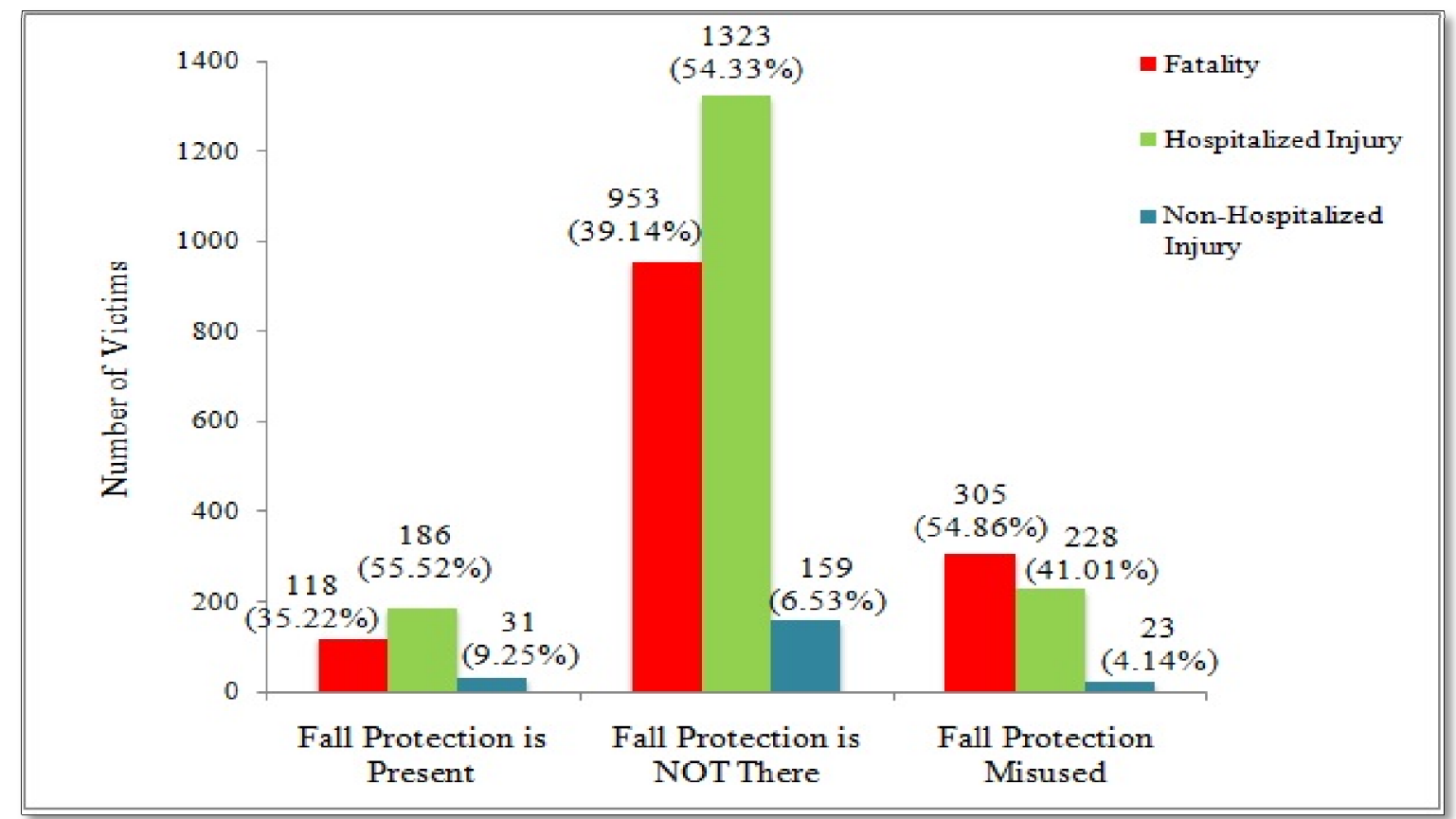

Figure 4-14: Class of injury vs. fall protection

Falls from the roofs (including skylights) constitute nearly $25 \%$ of all the fall accidents, and it is the leading cause of falls in the U.S. construction industry. The lion share of falls from the roof highlights the importance of this issue, and gravity of the problem currently faced by roofing industry and its workers. Roofers are usually involved in falls at heights $\leq 25 \mathrm{ft}$., as noted in the previous analysis. Fig 4-15 shows that nearly $54 \%$ of the times fall protection was missing in case roof falls. It was also noted that $29 \%$ 
of the workers got fatally injured in the presence of fall protection, whereas $48 \%$ of the workers suffered fatal injuries when the fall protection was missing. Falls from the roofs, mostly results in serious injuries (hospitalizations) and fatalities, as there were only handful of minor injuries (non-hospitalization).

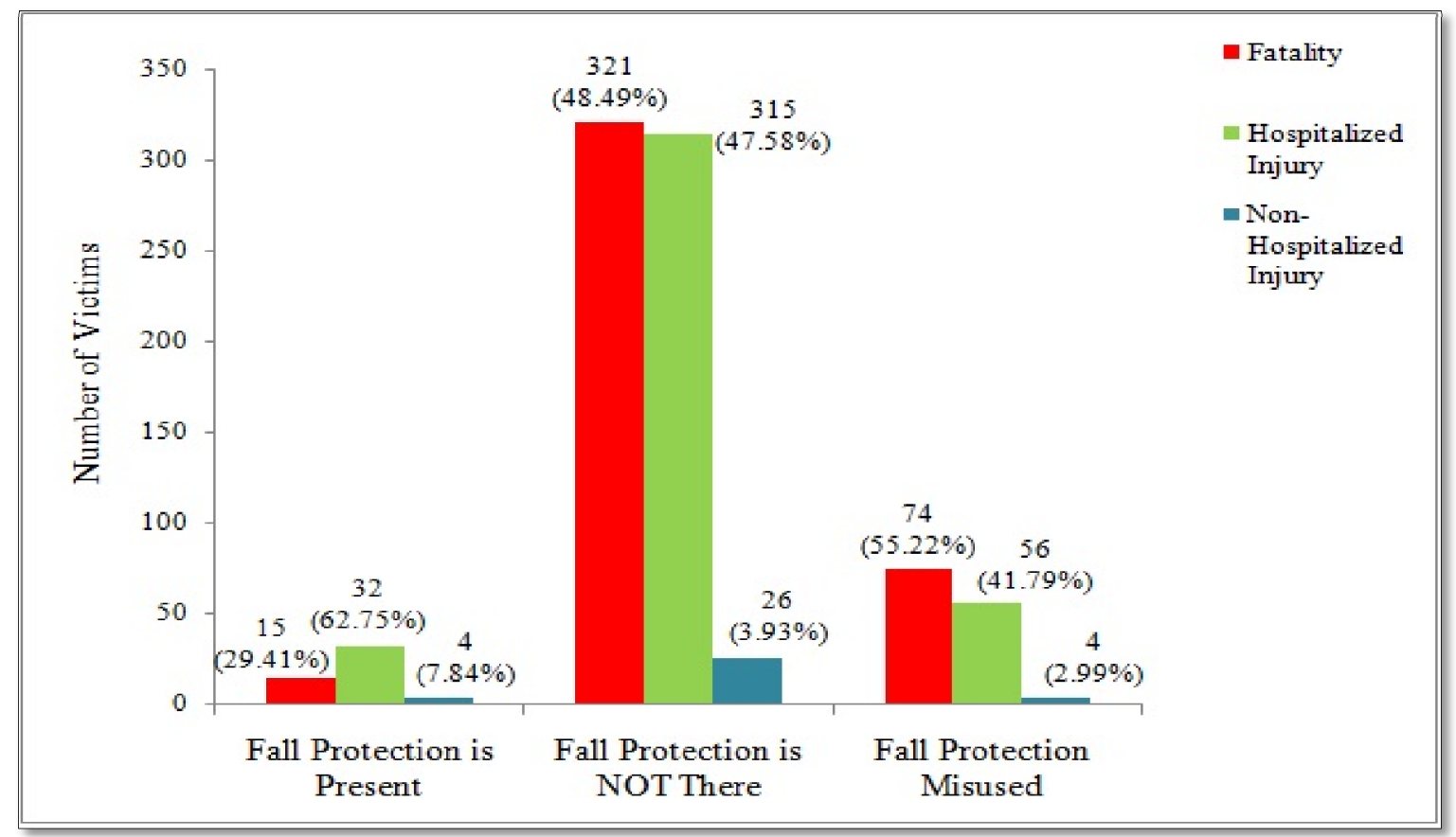

Figure 4-15: Nature of injury and fall protection usage in roof fall accidents

Fig 4-16 illustrates the results of the investigation that was performed in order to observe the situation of usage of fall protection in case of roof fall accidents. There were a total of 722 roofing accidents in which fall height and fall protection details were simultaneously available. It was found that in $79 \%$ of the cases there was no fall protection available on heights $\leq 25 \mathrm{ft}$., and these are the heights on which majority of roof fall accidents takes place, as noted in the previous analysis. Lack of fall protection may possibly be the cause for majority of the roof falls. 


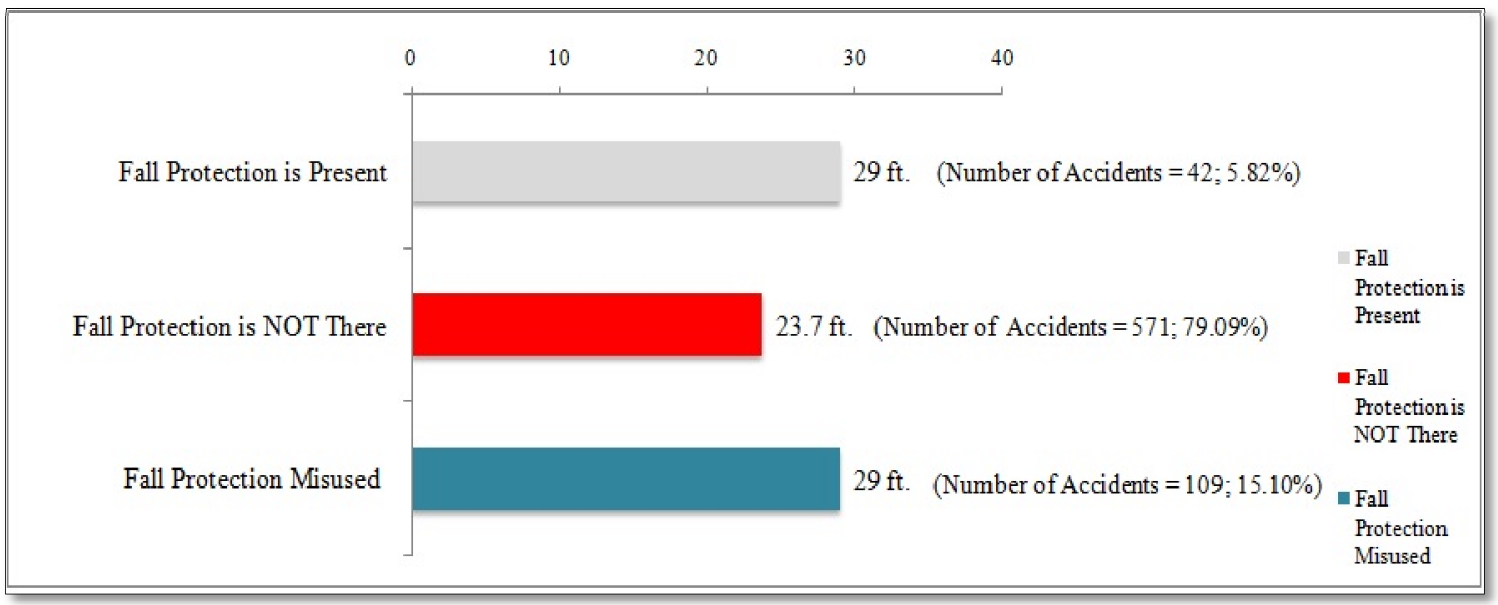

Figure 4-16: Average height of fall in roofing vs. fall protection

As discussed in the literature review, OSHA has a different fall protection standard for structural steel erection works. The minimum height on which fall protection should be provided is $15 \mathrm{ft}$., unlike $6 \mathrm{ft}$. rule that is applicable to all other types of construction works. Fig 4-17 presents the state of compliance to regulations for SIC-1791 (Structural Steel Erection). There were 333 cases for which fall protection details were simultaneously available. The analysis for this parameter is performed with respect to the number of victims, since it is a victim specific parameter. The total numbers of victims were 352 , and it has been found that, 211 victims (60\%) were unequipped with the fall protection tools. It was noted that $38 \%$ of the workers got fatally injured in the presence of fall protection, whereas $54 \%$ of the workers suffered fatal injuries when the fall protection was missing. Since the nature of work involves working at greater heights, it found that only 5\% (18 victims) of the victims received non-hospitalized injuries, whereas remaining victims were found to be critically injured. The results show a high level of non-compliance to the regulations and calls for a need of increased training efforts, as the fall protection requirements are already relaxed for this particular trade 
keeping in view the rigorous training requirements of structural steel workers. Further discussion regarding this is made in the discussion chapter.

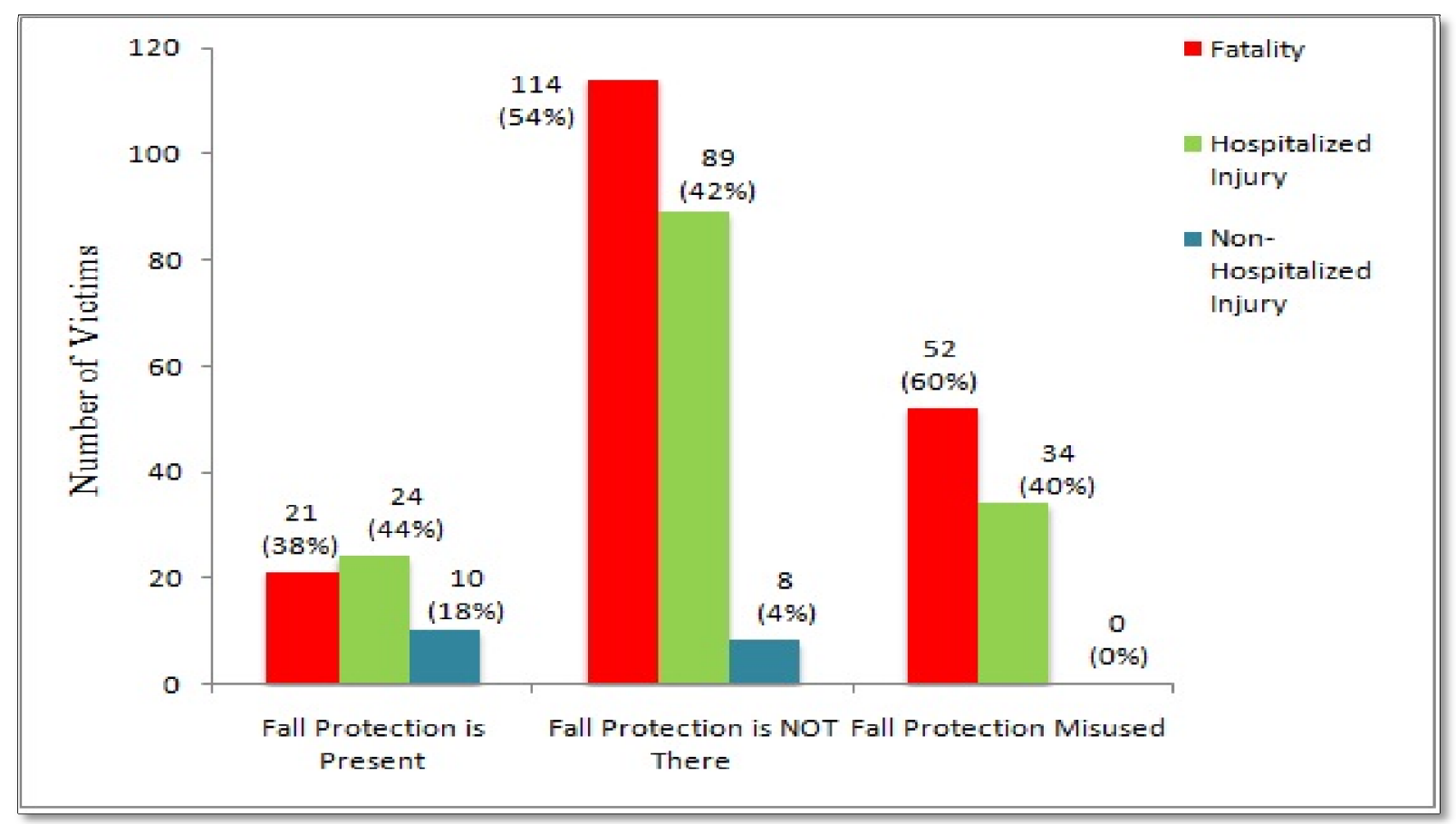

Figure 4-17: Nature of injury and fall protection usage in structural steel erection

(SIC-1791)

\subsubsection{Nature of Injury Caused by Fall Accident}

There are different types of injuries that can result as a consequence of a falling accident. OSHA records the type of injury that is incurred to the victim. This parameter has been analyzed with respect to the number of victims, since it is a victim specific parameter. An accident may involve more than one victim, which might suffer from different types of injuries. The descriptive analysis revealed that fracture is the most recurring injury, as it has been found that more than $50 \%$ of the accidents result in fracture (s) to the victims (Fig 4-18). The severity of the problem with a fracture injury 
can be ascertained from the fact that a single fracture may cost up to $\$ 100,000$, as per the estimate from OSHA's online injury cost calculator. This amount may lead a small company to closure, as generally small companies may not be able to absorb such financial setbacks. Further discussion regarding this parameter will be done in the discussion chapter.

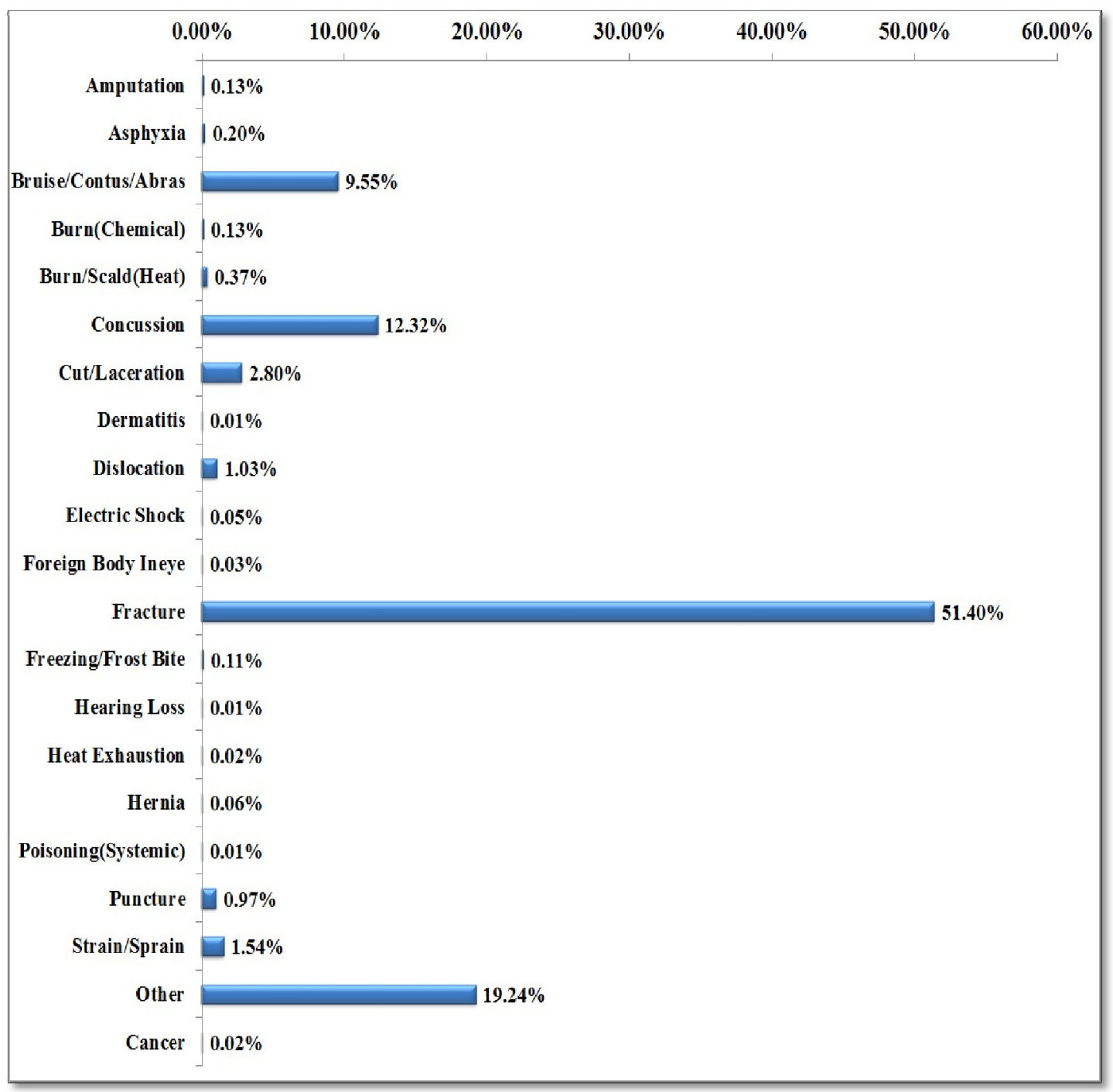

Figure 4-18: Nature of injuries in case of fall accidents 


\section{CHAPTER 5: DISCUSSION}

Falls are the main cause of accidents in the U.S. construction industry, as it responsible for highest number of injuries and fatalities. Falls are responsible for nearly half of the accidents in the U.S. construction industry. After electrocution accidents, falls are the most dangerous accidents in terms of the severity of an accident; $92 \%$ of the fall victims were either hospitalized or got fatally injured.

Specialty trade contractors are found to be more vulnerable to fall accidents as they were involved in $75 \%$ of the fall accidents that occurred in the U.S. construction industry in the last two decades. This is may be due to their greater presence in the U.S. construction industry as compared to the other two SIC codes. The details about the registered number of businesses in the construction industry's SIC codes show that there are 703,959, 66,329 and 1,023,692 registered businesses for SIC-15, 16 and 17 respectively (NAICS). SIC-17 (specialty trade contractors) has 32\% more registered business entities than SIC-15 (building construction) and 93\% more registered business entities than SIC-16 (heavy construction). Specialty trade contractor's greater footprint in the construction industry could be a possible factor indicating the reason of high occurrence of accidents in that particular category. Specialty trade contractors' exhibits poor safety record, as they are the most cited industrial category for fall protection related violations in 2010 (The Construction Chart Book, 2013). Specialty trade contractors tend to be small companies and higher influx of new workers with such contractors perhaps increase the chances of accidents as these contractors usually do not provide formal safety training and education to their workers (Hinze and Gambatese, 2003). 
Fall accidents are found to be heavily concentrated in single family dwelling and commercial building projects as $60 \%$ of the falls were recorded on such projects. When the findings of this study were compared to Huang and Hinze (2003), there has been a significant increase (61\%) noted in the case of fall accidents on single family dwelling projects. This increase of fall accidents in case of single family dwelling projects, might be linked to the fact that the spending on private residential construction projects increased in the early 2000's and gained its peak in 2006 (The Construction Chart Book, 2013). Higher concentration of fall accidents in the residential projects category may possibly be related to the fact that there were more residential projects as compared to the nonresidential projects in the last decade. Fig 5-1 illustrates the trend of spending on residential vs. non-residential projects from 1993 to 2010 (The Construction Chart Book, 2013).

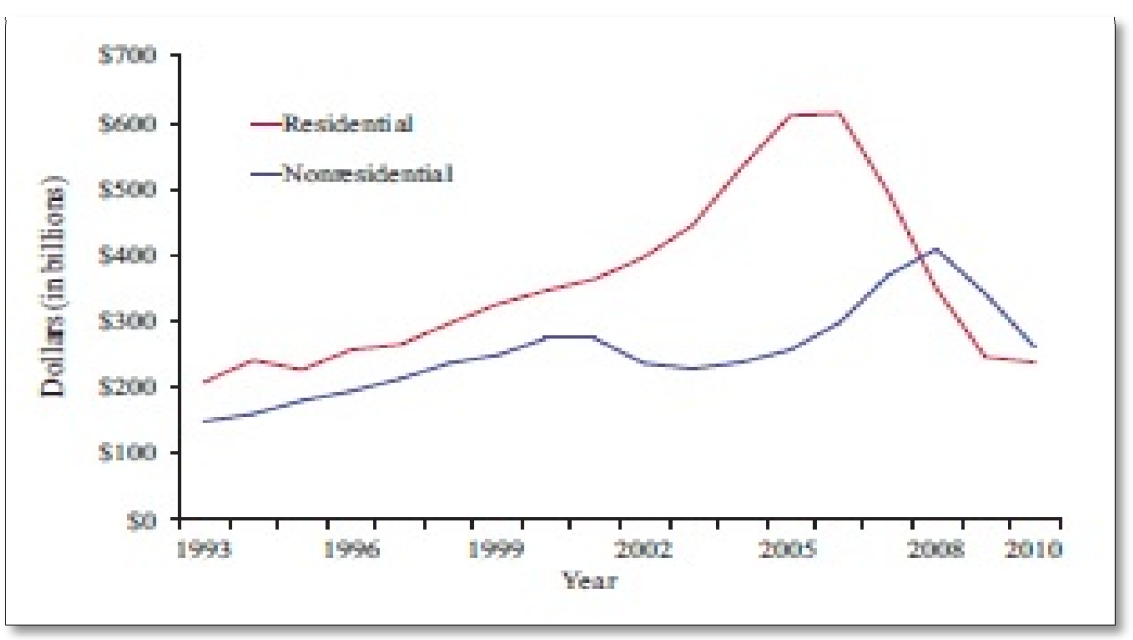

Fig 5-1: Value of residential vs. non-residential construction, 1993-2010 (The Construction Chart Book, 2013) 
Huang and Hinze (2003) studied the dataset from 1997-2001, whereas this study analyzed OSHA's IMIS database from 1994 till 2013. Therefore, the noted increase in fall accidents in case of single family housing projects could be related to the circumstance that there was more activity in the residential construction sector as compared to other types of projects. Moreover, residential construction projects are usually executed by small contractors who lack safety culture, due to limited financial resources and lack of training and education (Dong et al., 2009, Sa et al., 2009).

There are various occupational/ trade categories in three SIC codes of the construction industry. SIC-1761 (roofing, siding and sheet metal work) was found to be the leading profession having highest fall accidents, followed by SIC-1751 (carpentry) and SIC-1791 (steel erection works) on spot two and three respectively. There has been a prominent increase noted in falls in the carpentry trade, when the findings of this study were compared to Huang and Hinze (2003) and Bobick (2004). Fig 5-2 illustrates the share of work done by selected specialty trade contractors in the residential construction sector (The Construction Chart Book, 2013). The two leading categories "framing" and "finish carpentry" works are executed by carpenters. Therefore, the noted increase in falls, in the carpentry trade may possibly be due to the increased activity in the residential construction sector of the U.S. (The Construction Chart Book, 2013), which involved high share of work to be performed by the carpenters. The business trends of the housing industry tends to affect the specialty trade contractors too since a major portion of work in the residential construction sector is subcontracted to various specialty trade contractors (The Construction Chart Book, 2013). 


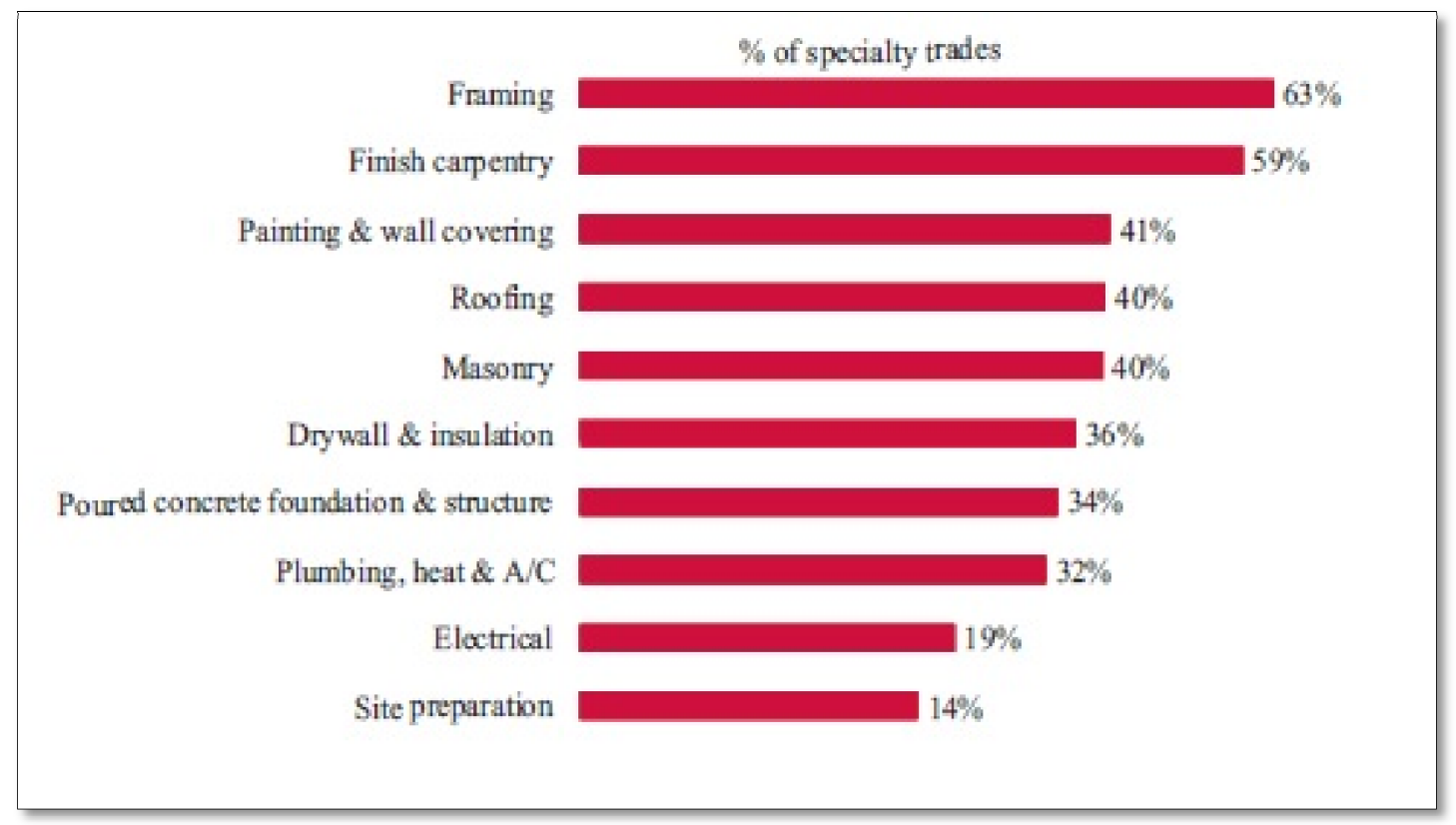

Fig 5-2: Work done in residential construction sector by selected specialty trades, 2007

(The Construction Chart Book, 2013)

In terms of the project budget, it was noted that fall accidents mostly happen on low cost projects, as nearly half of the falls were recorded on projects with budgets under $\$ 250,000$. This might be due to the fact that such smaller budget projects are usually executed by small specialty contractors, who do not have much awareness about safety and due to their limited financial maneuverability they lack in providing formal safety education and training to their workforce, which ultimately leads to increased chances of accidents. Previous studies also highlighted the problem of poor safety in case of small contractors (Dong et al., 2009; Sa et al., 2009). Moreover, small companies have less manpower and resources and their manpower is not usually trained which ultimately leads to accidents. 
Falls from the roofs are the leading cause of fall accidents in the U.S. construction industry followed by falls from ladders and falls from scaffolds. These three fall causal codes are responsible for more than half of the falls in the U.S. construction industry. There has been a prominent increase (50\%) noted in case of falls from/ with ladders when the results of this study were compared to Huang and Hinze (2003). Ladders are used extensively during residential construction, almost by every subcontractor (e.g. roofers, painters, plumbers, carpenters). The working heights in housing construction allow ladders to be a handy aid to perform various tasks. So the usage of ladders is supposed be more in the residential construction sector as compared to nonresidential sector. In the high rise/ nonresidential projects, there is a greater usage of scaffolds, due to greater working heights and different work requirements. The increase in falls from the ladders may possibly relate to the fact that there were more residential projects during the reported time. More residential projects means a higher number of specialty trade contractors working on housing projects, and their nature of work generally requires the usage of ladders. Moreover, the analysis of U.S. BLS (2003-2010) fatalities data also showed a rising pattern in case of fatal falls from ladders. This is the same tenure when residential construction industry of the U.S. attained its peak as illustrated in Fig 5-1. Therefore, increase in falls from the ladders may perhaps be related to high activity of the specialty trade contractors in the residential construction sector of the U.S.

In regards to fall height, it has been found that $85 \%$ of the falls occur on heights $\leq 30$ $\mathrm{ft}$. and majority of accidents were recorded on working heights ranging in between $10 \mathrm{ft}$. to $20 \mathrm{ft}$. When the findings of this research were compared to Huang and Hinze (2003), 
there has been a significant increase (54\%) noted in falls between $10 \mathrm{ft}$. to $20 \mathrm{ft}$. heights. This increase could be due to multiple reasons. The usual working heights in case of housing projects also fall in the similar height range (10 to $20 \mathrm{ft}$.). Sa et al. (2009) reported average working heights for residential roofers in the range of 11-15 ft. Therefore increased falls on such heights may possibly be linked to the increased business activity in the residential construction industry as reported in the construction chart book, 2013. Specialty trade contractors are directly involved in the residential construction industry and usually work within the same height range in different professions such as roofers, carpenters, painters, etc. Increase in falls on heights between $10 \mathrm{ft}$. to $20 \mathrm{ft}$. might also be related to the rise in the residential construction sector.

As reported in the construction chart book, 2013, fall protection is the most cited violation by OSHA in 2010 (Fig 5-3). Despite these alarming facts, 66\% of the IMIS database does not contain any information about the usage of fall protection. With a greater availability of the data, researchers could expand their horizon of study regarding fall accidents, and a workable solution could be made to control these accidents. OSHA should make every possible effort to record every detail of the accident, so that it may be used for future studies by the researchers, and regulators may also utilize it to study the situation of usage of fall protection tools in the construction industry. The greater the data, the greater would be the accuracy of results. 


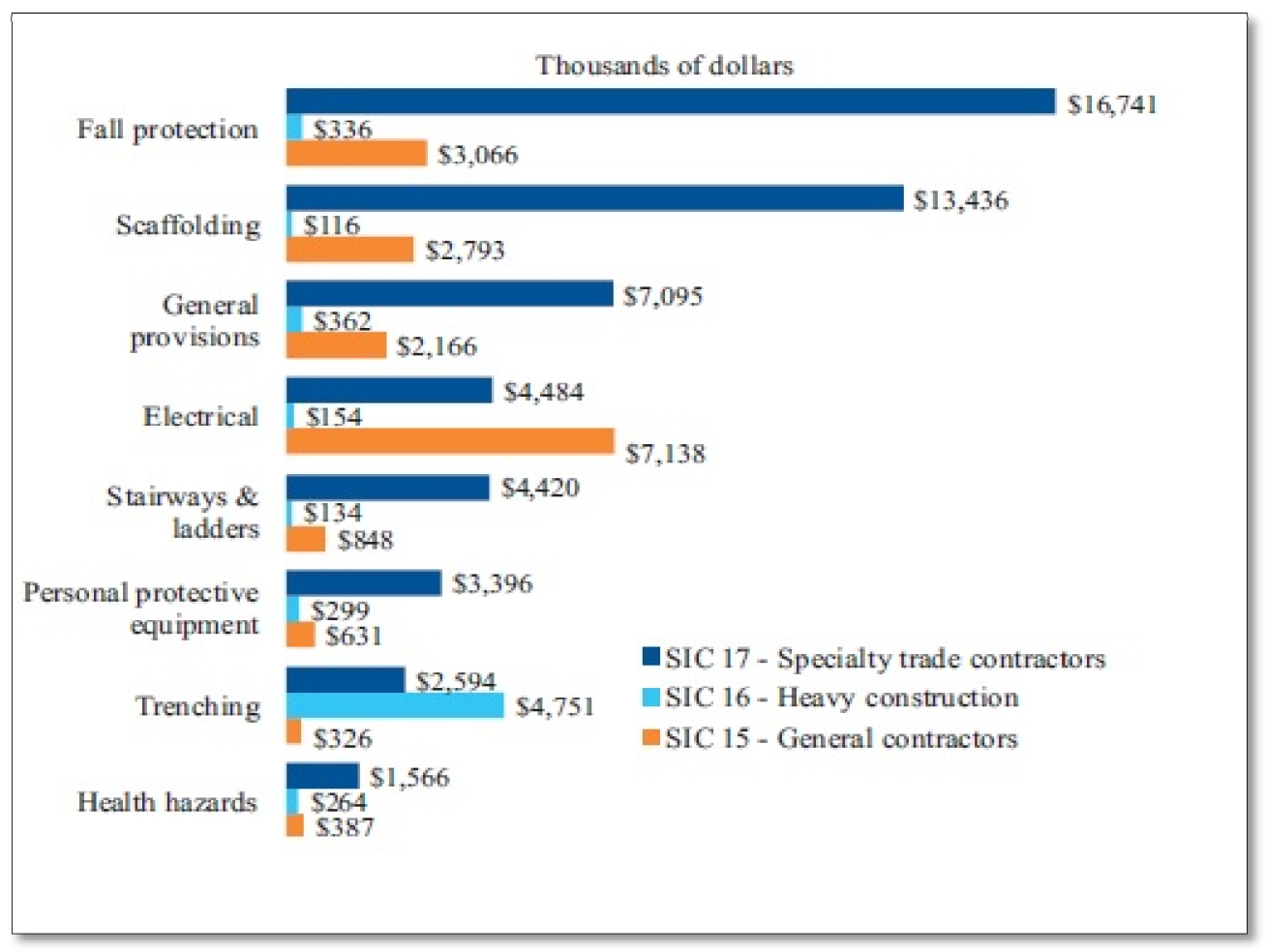

Fig 5-3: OSHA's federal citations by major violation category and construction sector, 2010 (The Construction Chart Book, 2013)

Fig 5-3 elucidates that specialty trade contractors had majority of the fall protection related citations additionally to the highest penalty amount (The Construction Chart Book, 2013). High degree of non-compliance to the regulations is noted in the analysis phase, as it was found that there was lack of fall protection in $73 \%$ of the cases. Moreover, it has been found that there is a greater percentage of lack of fall protection on heights $\leq 30 \mathrm{ft}$., and these are the heights where majority of fall accidents take place. It was noted that the trend of usage of fall protection is increased with the increase of working heights. It might be due to the fact that projects which involve working on heights $>40 \mathrm{ft}$., are usually nonresidential projects executed by big and well-trained contractors who follow safety regulations. Moreover at bigger projects the main 
contractor might obligate its subcontractors to follow proper safety regulations which lead to greater compliance and usage of fall protection. Whereas, higher percentage of lack of fall protection on heights $<30 \mathrm{ft}$., suggests that these are mostly residential construction projects, executed by small specialty contractors who lack safety culture. In terms of work hours, small contractors who usually work on residential projects at heights $<30 \mathrm{ft}$. may have more work hours as compared to big contractors who usually work on big projects. So, in that case it is implied that number of fall accidents is more in case of bigger contractors as compared to small ones. This particular detail cannot be validated at this stage as it is out of scope of this study. The findings also suggest that usage of fall protection is triggered by increase in working heights. At heights $<30 \mathrm{ft}$., the workers might feel confident and ignore the usage of fall protection. Greater proportion of fall accidents between $10 \mathrm{ft}$. to $20 \mathrm{ft}$. working heights could also be due to a higher percentage of absence of fall protection at such heights and increased business activity in the residential construction industry in the past decade.

OSHA has a different fall protection standard for the structural steel erection trade and falls were the highest cause of fatalities in this trade as noted by Beavers et al. (2009). In the case of steel erection works, the minimum height on which fall protection is mandatory is $15 \mathrm{ft}$., unlike $6 \mathrm{ft}$. rule that is applicable to all other types of construction works. This rule is a bit relaxed that might be due to the presumed notion that workforce in the steel erection industry are supposed to be well trained and educated as they have higher entry level education and training requirements as compared to other professions (Table 5-1). As illustrated in Table 5-1, structural iron and steel erectors have a 
requirement of additional formal training (apprenticeship) to attain competence in the field as compared to other professional trades that require short to moderate term on job training. Given that the workers have to go through proper training to work as a structural steel erector and their nature of work is risky; compensation of structural iron and steel erectors is also higher ( $\$ 46,140$ per year) as compared to other professions (U.S. BLS, 2014a), such as construction laborers and helpers make $\$ 29,160$ per year (U.S. BLS, 2014b) and roofers make $\$ 35,130$ per year (U.S. BLS, 2014c).

Table 5-1: Comparison of education requirements and compensation of different trades

(Source: U.S. BLS, 2014d)

\begin{tabular}{|c|c|c|c|}
\hline Parameters & $\begin{array}{c}\text { Structural Iron and } \\
\text { Steel Erectors }\end{array}$ & $\begin{array}{c}\text { Construction } \\
\text { Laborers and } \\
\text { Helpers }\end{array}$ & Roofers \\
\hline 2012 Median Pay & $\$ 46,140 /$ year & $\$ 29,160 /$ year & $\$ 35,290 /$ year \\
\hline $\begin{array}{c}\text { Entry-Level } \\
\text { Education }\end{array}$ & $\begin{array}{c}\text { High School diploma } \\
\text { or equivalent }\end{array}$ & $\begin{array}{c}\text { no specific } \\
\text { requirement }\end{array}$ & $\begin{array}{c}\text { Less than high } \\
\text { school }\end{array}$ \\
\hline $\begin{array}{c}\text { On-the-job } \\
\text { Training }\end{array}$ & Apprenticeship & $\begin{array}{c}\text { Short-term on-the- } \\
\text { job training }\end{array}$ & $\begin{array}{c}\text { Moderate-term } \\
\text { on-the-job training }\end{array}$ \\
\hline $\begin{array}{c}\text { Job Outlook, } \\
2012-22\end{array}$ & $\begin{array}{c}22 \% \text { (Much faster } \\
\text { than average) }\end{array}$ & $\begin{array}{c}25 \% \text { (Much faster } \\
\text { than average) }\end{array}$ & $\begin{array}{c}11 \% \text { As fast as } \\
\text { average) }\end{array}$ \\
\hline
\end{tabular}

So, in view of the background of these workers it was expected to observe a greater compliance to fall protection standards, but, unfortunately, it was found that at $60 \%$ of instances fall protection was missing. Since their nature of work involves working at greater heights, the resulting accidents mostly result in fatalities or hospitalized injuries. It was noted that only $5 \%$ of the victims received minor injuries, whereas, $53 \%$ victims were fatally injured, and $42 \%$ received hospitalized injuries. There were a few cases 
noted in the analysis phase in which a steel erector undergoes a fatal accident while working at a height that does not require any fall protection; the employer did not get cited as the site conditions were acceptable as per OSHA's steel erection fall protection standard. Therefore, in the light of above findings OSHA might need to revisit their fall protection standard for steel erectors, and may consider it making a bit stricter. Moreover, as per the U.S. BLS's industry outlook (2012-2022) for structural steel erection industry, it is predicted that it will grow much faster than the average. Therefore, the findings calls for increased efforts in educating the steel erectors about safety and fall protection, as there will be higher influx of new workers due to higher market demand, and that will in turn increase the chances of accidents.

Falls accidents generally results in major injuries. In case of resulting injuries due to falls it has been found that, fractures occur most frequently, as half of the victims in the past two decades experienced fractures followed by "other" injuries and concussion. As per the OSHA's online injury cost calculator, the cost of one single fracture can cost employer up to $\$ 100,000$ and a single concussion injury costs about $\$ 151,000$ (OSHA, 2013d). When these costs were compared to Bobick (2004), it has been found that the injury costs nearly doubled from 1998 to 2013. Small construction companies can easily go out of business as a result of any small accident; since a single fracture will cost around $\$ 100,000$, and the company that does low budget project for e.g. $\leq \$ 250,000$ would never be able to make up this expense and would go out of business even in case of a small injury. These are those low budget projects which experience more than half of the falls in the U.S. construction industry. Hence, the above discussion highlights the 
importance of safety education and training, which will ultimately help in running millions of small businesses, thus improving the economic situation of millions of people associated with the construction industry. These small businesses need special attention as they are the ones with most falls and they lack safety culture. Regulators should take certain steps to raise awareness about fall hazards and their consequences. Targeted inspections should be done frequently so that small companies would be compelled to enforce and comply with the standards. Moreover, regulatory agencies such as OSHA, $\mathrm{NIOSH}$, etc. are encouraged to provide free safety trainings especially to such small sized companies and provide them safety equipment on flexible payment schedule so that they may be able to own it, and train their workforce about the safe work practices.

In summing up the problem of falls in the U.S. construction industry, specialty trade contractors are found to be more susceptible to fall accidents. Specialty trade contractors tend to be small companies, and they exhibit poor safety record. Residential housing sector was found to have increased fall accidents and falls from the roofs are the leading cause of falls in the U.S. construction industry. Low-budget projects, which are usually executed by small specialty trade contractors, are found to be more vulnerable to falls. Regulators should take specific actions to target small specialty trade contractors working in the residential construction sector for the enforcement of regulations and standards. There can be improvement in the overall condition of safety in the construction industry, by specifically controlling the problem of non-compliance in low-budget, residential housing projects. 


\subsection{Contributions of this Research Study}

This study investigates the different causes, influential factors and dimensions of fall accidents in the U.S. construction industry, by examining the fall accident data from OSHA's IMIS database for the past twenty years. While there have been many studies investigating the fall accidents, the current body of knowledge lacked a latest study on fall accidents with a recent and updated data set. The last major study that analyzed OSHA's IMIS database for studying fall accidents was done by Huang and Hinze 2003, which analyzed the data from 1997-2001. Other previous studies (Sa et al., 2009, Johnson et al., 1998, Olbina et al., 2011, Hinze and Gambatese, 2003, Hung et al., 2012) were simply based on surveys or interviews, which represented a particular group of people for more specific topics. Some studies on the other hand, just focused on fatal accidents resulting due to falls (Beavers et al., 2009; Dong et al., 2009; Hatipkarasulu, 2010 Janicak, 1998, Suruda et al., 1995). Therefore, there was an immense need of a study identifying causes of fall accidents by analyzing the latest dataset; since, despite the decrease in accidents in the construction industry, falls remain to be a persistent problem. For that reason, this research presents updated analysis on fall accidents with respect to industry type, project type and size, and dimensions of fall accidents in terms of fall cause, fall height, and the current state of usage of fall protection. The findings of this study may possibly be considered more representational, about the characteristics of falls, since they are based on much bigger data set which means better justification of reported findings. 
Another contribution of this study is that, it has specifically analyzed the current state of usage fall protection in the U.S. construction industry. Majority of the previous studies have discussed the fall protection parameter for more specific conditions. The findings revealed that there was lack of fall protection in majority of the accidents. Although the usage of fall protection is found to be very less, it was noted that there is a greater usage of fall protection on heights $>40 \mathrm{ft}$., whereas there was lack of fall protection on heights $\leq 30 \mathrm{ft}$., and these are those heights where majority of fall accidents takes place. The findings suggest that the trend of usage of fall protection is triggered by heights, as workers' at lower heights, may possibly disregard fall protection tools due to overconfidence or carelessness.

\subsection{Future Research Direction}

In conclusion of this research project, it is noted that a future study is warranted, which should study and derive different types of models that could be opted for the implementation of safe work practices especially by small business owners (specialty contractors). It can be a qualitative research that would analyze the current situation and grievances of specialty trade contractors by conducting a survey and taking their point of view in regards to the problems faced by them and their views on how to promote safe work practices. A similar qualitative tool (e.g. interviews) could be used for the regulators (OSHA, NIOSH) as well, to take their opinions, on how to address this issue. Therefore, in that way a common ground could be reached upon to curb this problem of falls and promoting safe work practices. Since falls mostly occur on lower heights of residential housing and commercial projects that are generally constructed by small 
specialty contractors there is a need of an innovative safety model that would systematically address the current problem of poor safety especially amongst particular groups. The future research should be aimed to devise such a model that would confirm the implementation of safe work practices by small contractors / employers as they are the ones with the majority of fall accidents.

Another dimension of future research would be to investigate the trend of accidents, particularly falls nationwide in the U.S., as this study noted that California has abnormally large share in the contribution of accidents. Therefore, a future research is warranted to investigate the reason of high concentration of accidents in the state of California. Moreover, OSHA should revisit their steel erection standards which have different fall protection requirements. There have been a few cases in the last 20 years in which victim was working under $15 \mathrm{ft}$. height, fell somehow and suffered a serious injury or a fatality. No violation could be issued to the employer as the working conditions were satisfactory as per OSHA's fall protection standard for steel erection trade. 


\section{CHAPTER 6: CONCLUSIONS}

Falls are the prime cause of accidents in the U.S. construction industry, and they have the highest incidence rate. The purpose of this study was to investigate the main causes and influential factors leading to fall accidents the U.S. construction sector. The main contribution of this study was that, it has specifically analyzed the fall heights and the current situation of usage of fall protection by using actual accident database. Since there has been hardly any research done in the last decade, to analyze fall accidents by

examining the IMIS dataset; this study presents updated trends, causal factors and dimensions about fall accidents.

It has been noted that falls are the second most dangerous accidents, and they mostly lead to serious injuries or fatalities. The severity of the problem of "falls" in the U.S. construction industry can be ascertained from the fact that it is leading the list of OSHA's fatal four followed by electrocution, struck by, caught in/ between.

Specialty trade contractors were found to be more vulnerable to falls as they are involved in $73 \%$ of the fall accidents in the past two decades. Specialty trade contractors tend to be small companies with limited annual revenues and they generally have poor safety record. These might be the contributing factors leading to greater number of fall accidents in case of specialty trade contractors.

In terms of the project type, $60 \%$ of the fall accidents were recorded on new projects that involve construction of residential housing units and commercial buildings. There has been a significant increase noted in falls on single family dwelling projects in the past 
decade, which might be due to the boom in residential construction sector of the U.S. in the early 2000's (The Construction Chart Book, 2013). Moreover, specialty trade contractors are mainly involved in the construction of residential projects, and it might also be the cause of increased falls in the residential housing projects. In terms of the project budget, it was noted that approximately $50 \%$ of the falls takes place on projects with budgets under $\$ 250,000$. Fall accidents occur more frequently on projects with lesser budgets as compared to big and high budget projects. This might be due to the fact that, majority of the low-budget projects are executed by small contractors, who are more vulnerable to falls due lack of education and safety culture.

The findings of this study showed that falls from the roofs is the leading cause of fall accidents followed by falls from the ladders and scaffolds. These three fall types contributed to almost $55 \%$ of the falls in the U.S. construction industry. 'Roofing, siding and sheet metal works', 'carpentry works', 'structural steel erection works' and 'single family housing construction' trades are responsible for half of the falls in the U.S. construction industry. In terms of fall height, $85 \%$ of the fall accidents occurred on heights less than $30 \mathrm{ft}$., and most of them are not equipped with the fall protection tools.

Despite the fact that duty to have fall protection is the most cited violation for the past two years, i.e. 2012 and 2013, it is found that the current state of compliance to regulations is poor. It is also noted that usage of fall protection is correlated to heights. Workers are triggered to use fall protection at heights greater than $40 \mathrm{ft}$., but there is a high degree of non-compliance at heights less than $30 \mathrm{ft}$., which account for majority of the falls in the U.S. construction industry. 
Regardless of this alarming state of falls in the U.S. construction industry, only $34 \%$ of the accident investigation summaries contained information about fall protection usage. OSHA should make every possible effort to record all details of the accidents, so that it may be used for future studies by the researchers and regulators may also utilize it to study the trend of usage of fall protection. Moreover, OSHA should also make sure to get rid of the inconsistencies while recording accidents, as 258 accidents were identified in the data processing phase of this study, which had been wrongly coded as falls.

The current state of falls in the U.S. construction industry warrants further research into this subject. A study could be taken up to examine and derive different types of models that could be opted for the implementation of safe work practices especially by small specialty trade contractors, as they are the major contributors to falling accidents. Another dimension of future research would be to perform a state-wise analysis in terms of the numbers of accidents and particularly falls; since, the state of California exhibited abnormally large share in the total number of accidents that occurred nationwide. OSHA should also revisit their steel erection standards which have different fall protection requirements, and may consider making it a bit stricter, in light of the findings of this study. 


\section{LIST OF REFERENCES}

Beavers, J., Moore, J., and Schriver, W. (2009). Steel Erection Fatalities in the Construction Industry. Journal of Construction Engineering and Management, 135, 227-234.

Bobick, T. (2004). Falls through roof and floor openings and surfaces including skylights: 1992-2000. Journal of Construction Engineering and Management, 130, 895-907.

Bunn, T.L., Slavova, S., Bathke, A. (2007). Data linkages of inpatient hospitalization and workers' claims data sets to characterize occupational falls. Journal of the Kentucky Medical Association 105 (7), 313-320.

Bureau of Labor Statistics [BLS]. (2002). Work-related fatalities up in construction industry. Washington DC: U.S. Department of Labor. Retrieved from the World Wide Web: http://www.bls.gov/opub/ted/2002/sept/wk5/art04.htm

Bureau of Labor Statistics [BLS]. (2007). Construction. Washington DC: U.S. Department of Labor. Retrieved from the World Wide Web: http://www.bls.gov/oco/cg/cgs003.htm

Bureau of Labor Statistics [BLS]. Construction. Washington DC: U.S. Department of Labor. Table A-9: Fatal occupational injuries by event or exposure for all fatal injuries and major private industry sector, All United States (2003-2010). Retrieved from the World Wide Web: http://www.bls.gov/iif/oshwc/cfoi/cftb0250.pdf

Bureau of Labor Statistics [BLS]. (2012).Census of Fatal Occupational Injuries Summary. Retrieved Nov 12, 2013 from the World Wide Web: http://www.bls.gov/news.release/cfoi.nr0.htm

Bureau of Labor Statistics [BLS]. (2014a). Retrieved Feb 17, 2014 from The World Wide Web: http://www.bls.gov/ooh/construction-and-extraction/structural-iron-and-steel-workers.htm

Bureau of Labor Statistics [BLS]. (2014b). Retrieved Feb 19, 2014 from The World Wide Web: http://www.bls.gov/ooh/construction-and-extraction/construction-laborers-and-helpers.htm

Bureau of Labor Statistics [BLS]. (2014c). Retrieved Feb 19, 2014 from The World Wide Web: http://www.bls.gov/ooh/construction-and-extraction/roofers.htm

Bureau of Labor Statistics [BLS]. (2014d). Occupational Outlook Handbook. Retrieved Feb 19, 2014 from The World Wide Web: http://www.bls.gov/ooh/

Chen, J., Fisher, D., and Krishnamurthy, K.. (1994). Development of Computerized System for Fall Accident analysis and Prevention. Journal of Computers and Industrial Engineering Vol. 28, No. 3, pp-457-466.

Choi, S., Fredericks, T., Abudayyeh, O., \& Keslinke, K. (2003). A review of costs of injuries in the roofing industry. Proceedings of the 8th annual international conference on industrial engineering theory, applications, and practice, Las Vegas, Nevada. 
Dong, X.S., Fujimoto, A., Ringen, K. and Men, Y. (2009). Fatal falls among Hispanic construction workers. Journal of Accident Analysis and Prevention, 41, 1047-52. 21.

Engineering News Record (ENR). (1990). Costs of Accidents is hidden. ENR, 225(24), 20-

Fredericks, T.K., Abudayyeh, O., Choi, S.D. (2005). Occupational injuries and fatalities in the roofing contracting industry. Journal of Construction Engineering and Management, 131(11), $1233-1240$.

Gambatese, J.A., Behm, M. and Rajendran, S. (2008). Design's role in construction accident causality and prevention: perspectives from an expert panel. Journal of Safety Science, 46, 67591.

Gavious, A., Mizrahi, S., Shani, Y. and Minchuk, Y. (2009). The costs of industrial accidents for the organization: developing methods and tools for evaluation and cost benefit analysis of investment in safety. Journal of Loss Prevention in the Process Industries, 22, 434-8.

Glenn, W. (2000). Safety in residential construction. Master's thesis, Univ. of Florida, Gainesville, $\mathrm{Fl}$.

Hallowell, M. (2010). Cost-effectiveness of construction safety programme elements. Construction Management and Economics, 28, 25-34.

Hatipkarasulu, Y. (2010). Project level analysis of Special Trade Contractor fatalities using accident investigation reports. Journal of Safety Research, 41, 451-457.

Henderson, R. (2012). Employment Outlook 2010-2020- Industry Employment and Output Projections to 2020. U.S.BLSPublications. Retrieved from http://www.bls.gov/opub/mlr/2012/01 /art4full.pdf.

Hinze, J. (1997). Construction safety, Prentice-Hall, Upper Saddle River, N.J.

Hinze, J and Applegate, L. (1991). Cost of Construction Injuries. Journal of Construction Engineering and Management, 117(3), 537-550.

Hinze, J and Russell, D. (1995). Analysis of fatalities recorded by OSHA. Journal of Construction and Management, 121(2), 209-214.

Hinze, J. and Gambatese, J. (2003). Factors that influence safety performance of specialty contractors. Journal of Construction Engineering and Management 159-164, March/ April 2003.

Hu, K., Rahmandad, H., Smith-Jackson, T., Winchester, W. (2011). Factors influencing the risk of falls in the construction industry: a review of evidence. Construction Management and Economics, 29, 397-416.

Huang, X., and Hinze, J. (2003). Analysis of Construction Worker Fall Accidents. Journal of Construction Engineering and Management, 129:262-271. 
Hung, Y., Winchester, W., Jackson, T., Kleiner, B., Reeves, K., and Mills, T. (2012). Identifying fall-protection training needs for residential roofing subcontractors. Journal of Applied Ergonomics, 44, 372-380.

Janicak, C. (1998). Fall-Related Deaths in the Construction Industry. Journal of Safety Research, Vol. 29, No. 1, pp. 35-42.

Johnson, H. M., Singh, A., \& Young, R. H. F. (1998). Fall protection analysis for workers on residential roofs. Journal of Construction Engineering and Management, 124, 418-428.

Lipscomb, H. J., Glazner, J., Bondy, J., Lezotte, D., \& Guarini, K.. (2004). Analysis of Text from Injury Reports Improves Understanding of Construction Falls. Journal of Occupational and Environmental Medicine, 46, 1166-1173.

Lipscomb, H. J., Glazner, J., Bondy, J., Guarini, K. and Lezotte, D. (2006). Injuries from slips and trips and construction. Journal of Applied Ergonomics, 37, 267-74.

North American Industrial Classification System (NAICS). Data retrieved from http://www.naics.com/sic-codes-counts-division/?minsic=15\&maxsic=17, at January 15, 2014.

National Institute for Occupational Safety and Health [NIOSH]. (2002). Worker Health Chart book 2000 - Nonfatal Injury. DHHS (NIOSH) Publication No. 2002-119 Cincinnati, OH: Author.

National Institute for Occupational Safety and Health [NIOSH]. (2004). Worker Health Chart book 2004. DHHS (NIOSH) Publication No. 2004-146 Cincinnati, OH: Author.

National Safety Council [NSC]. (2008). Fatalities by Industry Sector. Retrieved from the World Wide Web: http://www.nsc.org/stateofsafety08.htm. Itasca, IL: Author.

Occupational Safety and Health Administration (OSHA). (1990). Analysis of construction fatalities-The OSHA data base 1985-1989, U.S. Department of Labor, Washington, D.C.

Olbina, S., Hinze, J., and Ruben, M. (2011). Safety in roofing. Occupational Hazards Peer reviewed article, www.asse.org.

Occupational Safety and Health Administration (OSHA, 2012). OSHA Outreach Training Program. Retrieved from the World Wide Web: http://www.osha.gov/dte/outreach/index.html.

Occupational Safety and Health Administration (OSHA 2013a). Retreived Nov 12, 2013 from the World Wide Web https://www.osha.gov/oshstats/commonstats.html

Occupational Safety and Health Administration (OSHA, 2013b). Retrieved Nov 20, 2013 from the World Wide Web: https://www.osha.gov/stopfalls/

Occupational Safety and Health Administration (OSHA, 2013c). Retrieved Nov 20, 2013 from the World Wide Web: https://www.osha.gov/Top_Ten_Standards.html

Occupational Safety and Health Administration (OSHA 2013d). Retreived Nov 12, 2013 from the World Wide Web https://www.osha.gov/dcsp/smallbusiness/safetypays/estimator.html 
Occupational Safety and Health Administration (OSHA). Retrieved from the World Wide Web: https://www.osha.gov/SLTC/etools/construction/falls/mainpage.html

Sa, J., Seo, D., Choi, S. (2009). Comparison of Risk Factors for Falls from height between commercial and residential roofers. Journal of Safety Research, 40, 1-6.

Suruda, A., Fosbroke, D., \& Braddee, R. (1995). Fatal work-related falls from roofs. Journal of Safety Research, 26, 1-8.

Teicholz, P. (2013). Labor-Productivity declines in the Construction Industry: Causes and Remedies (Another look). Analysis, Research and Reviews of AEC Bytes. Retrieved Dec 6, 2013 from the World Wide Web http://www.aecbytes.com/viewpoint/2013/issue_67.html

The Construction Chart Book $5^{\text {th }}$ Edition (April, 2013). The Center of Construction Training and Research (CPWR). 